\title{
HYDROGEOLOGY AND GROUND-WATER
}

QUALITY OF THE CHROMIC ACID PIT SITE, U.S. ARMY AIR DEFENSE ARTILLERY CENTER AND FORT BLISS, EL PASO, TEXAS

By Cynthia G. Abeyta and Carole L. Thomas

U.S. GEOLOGICAL SURVEY

Water-Resources Investigations Report 96-4035

Prepared in cooperation with the U.S. DEPARTMENT OF THE ARMY, U.S. ARMY AIR DEFENSE ARTILLERY CENTER AND FORT BLISS

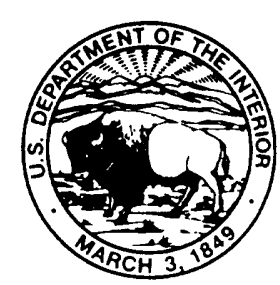

Albuquerque, New Mexico 1996 


\section{U.S. DEPARTMENT OF THE INTERIOR \\ BRUCE BABBITT, Secretary \\ U.S. GEOLOGICAL SURVEY \\ Gordon P. Eaton, Director}

For additional information write to:

District Chief

U.S. Geological Survey

Water Resources Division

4501 Indian School Road NE, Suite 200

Albuquerque, New Mexico 87110-3929
Copies of this report can

be purchased from:

U.S. Geological Survey

Earth Science Information Center

Open-File Reports Section

Box 25286, MS 517

Denver Federal Center

Denver, Colorado 80225 


\section{CONTENTS}

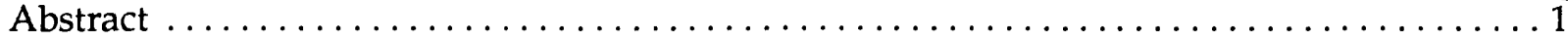

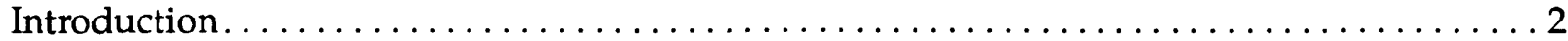

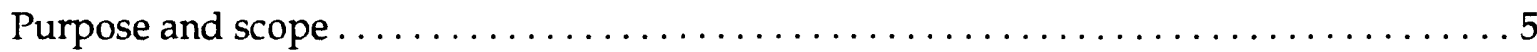

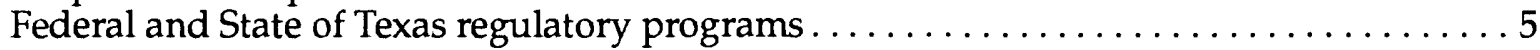

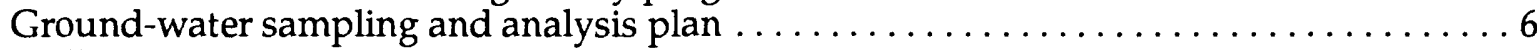

Well-numbering system. . . . . . . . . . . . . . . . . . . .

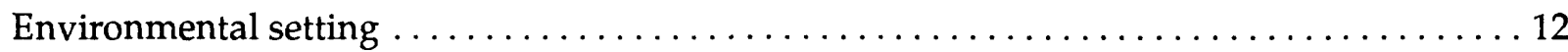

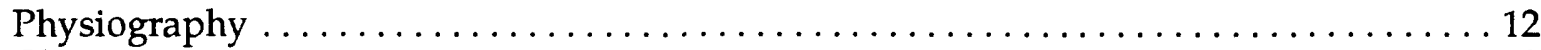

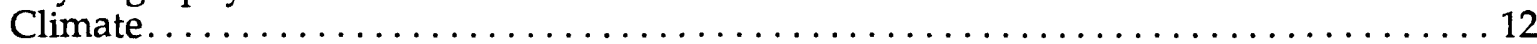

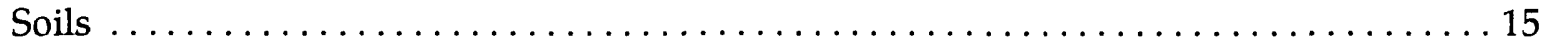

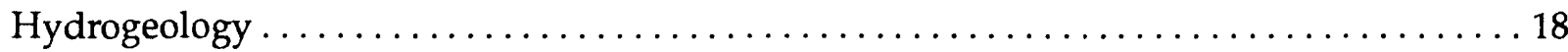

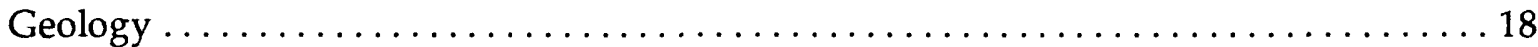

Hydrology . . . . . . . . . . . . . . . . . . . . . 25

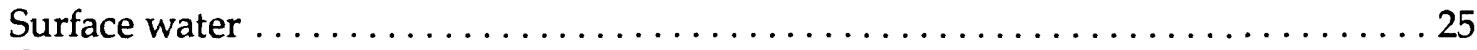

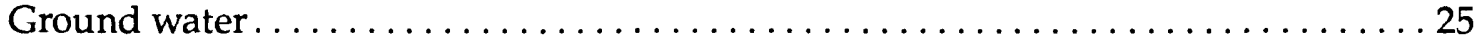

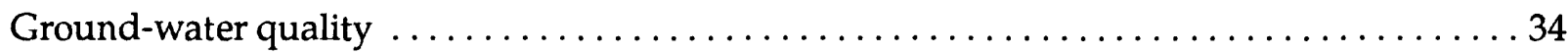

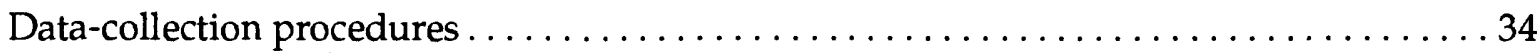

Quality assurance/quality control and review of analytical data $\ldots \ldots \ldots \ldots \ldots \ldots 35$

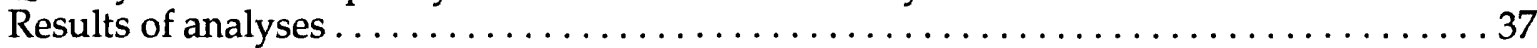

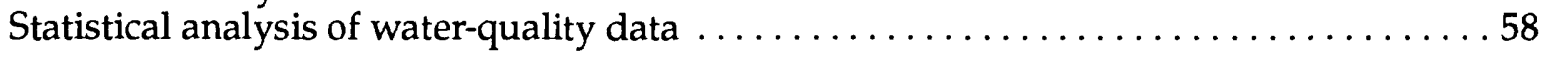

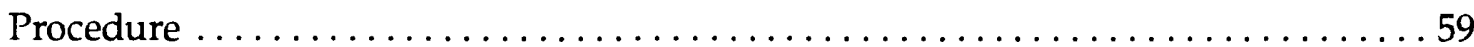

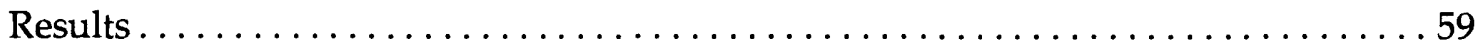

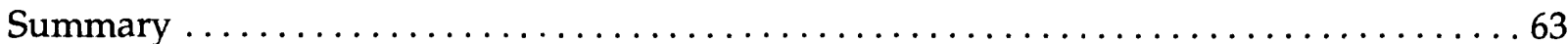

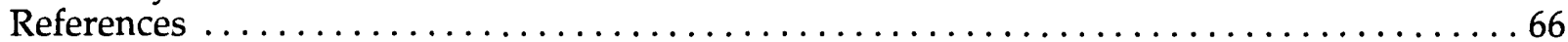

\section{FIGURES}

Figure 1. Map showing location of U.S. Army Air Defense Artillery Center and Fort Bliss military reservation, Texas and New Mexico. . . . . . . . . . 3

2. Map showing location of Chromic Acid Pit site and monitoring wells, U.S. Army Air Defense Artillery Center and Fort Bliss, El Paso, Texas . . . . . . .4

3. Diagram showing well completion of Chromic Acid Pit ground-water

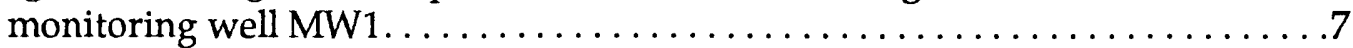

4. Diagram showing well completion of Chromic Acid Pit ground-water

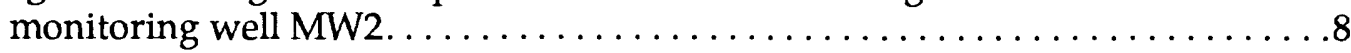




\section{FIGURES--Concluded}

Figure 5. Diagram showing well completion of Chromic Acid Pit ground-water monitoring well MW3. . . . . . . . . . . . . . . . .

6. Diagram showing Texas well-numbering system $\ldots \ldots \ldots \ldots \ldots \ldots \ldots \ldots$

7. Map showing physiographic structures of the Tularosa Basin and

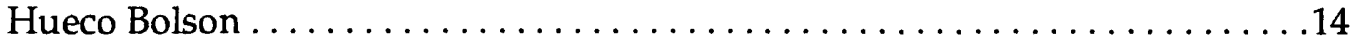

8. Geologic section of the Hueco Bolson. . . . . . . . . . . . . . . . 19

9-11. Diagrams showing geophysical logs and interpreted lithologies at:

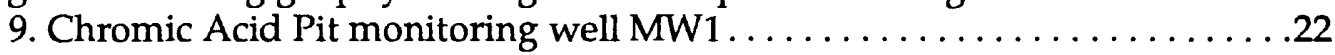

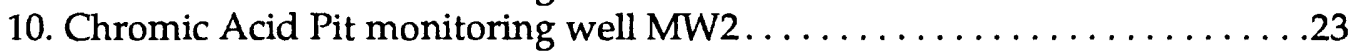

11. Chromic Acid Pit monitoring well MW3 .................. 24

12. Map showing elevation of the potentiometric surface and direction of groundwater flow in the vicinity of the Chromic Acid Pit site, El Paso, Texas,

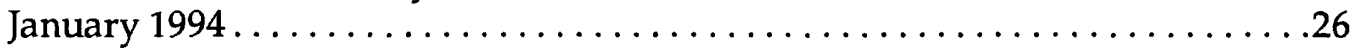

13-16. Diagrams showing water-table elevation and direction of ground-water flow in the vicinity of the chromic acid pit:

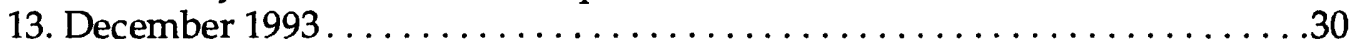

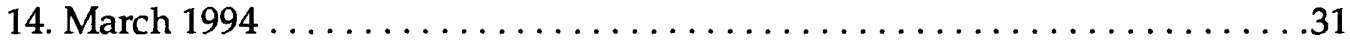

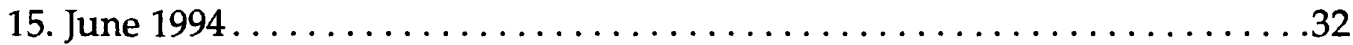

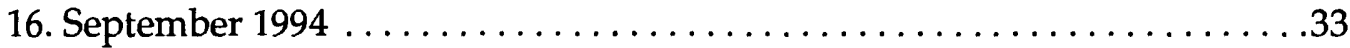

17. Geologic section showing ground-water occurrence in the Hueco Bolson . . . . . .38

18. Flowchart showing methods used for statistical analysis of water-quality data

\section{TABLES}

Table 1. Analytical constituents and methods used for ground-water monitoring at the Chromic Acid Pit site, December 1993 . . . . . . . . . . . . . . . . . 10

2. Analytical constituents and methods used for quarterly ground-water monitoring at the Chromic Acid Pit site subsequent to December 1993 . . . . . 11

3. Evaporation, in inches, from class $A$ evaporation pan at Ysleta, Texas, 1985-92.

4. Engineering classification and estimated engineering properties of soil at the Chromic Acid Pit site. 


\section{TABLES--Concluded}

Page

Table 5. Driller's log of material penetrated by Chromic Acid Pit borehole MW1 ......20

6. Driller's log of material penetrated by Chromic Acid Pit borehole MW2 . . . . 21

7. Driller's log of material penetrated by Chromic Acid Pit borehole MW3.......21

8. Records of wells in the vicinity of the Chromic Acid Pit site, El Paso, Texas . . . .27

9. Water-level data for Chromic Acid Pit monitoring wells MW1, MW2,

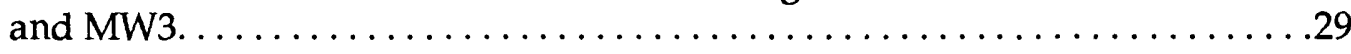

10. Chemical data for water from wells in the vicinity of the Chromic Acid

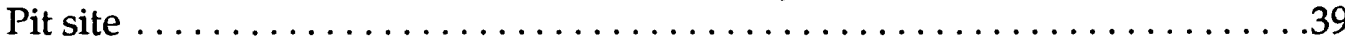

11. Analytical results of quarterly ground-water monitoring at the Chromic Acid Pit site, U.S. Army Air Defense Artillery Center and Fort Bliss, El Paso, Texas, first quarter, December 1993

12. Analytical results of quarterly ground-water monitoring at the Chromic Acid Pit site, U.S. Army Air Defense Artillery Center and Fort Bliss, El Paso, Texas, second quarter, March 1994.

13. Analytical results of quarterly ground-water monitoring at the Chromic Acid Pit site, U.S. Army Air Defense Artillery Center and Fort Bliss, El Paso, Texas, third quarter, June 1994

14. Analytical results of quarterly ground-water monitoring at the Chromic Acid Pit site, U.S. Army Air Defense Artillery Center and Fort Bliss, El Paso, Texas, fourth quarter, September $1994 \ldots \ldots \ldots \ldots \ldots \ldots \ldots \ldots . \ldots . \ldots 2$

15. Data-qualifier codes used to qualify water-quality data $\ldots \ldots \ldots \ldots \ldots \ldots 54$

16. Summary of maximum contaminant levels for selected water-quality properties and constituents for public water-supply systems . . . . . . . . . 57

17. Results of statistical testing of water-quality data for the U.S. Army Air Defense Artillery Center and Fort Bliss, chromic acid pit, El Paso, Texas, December 1993 through September $1994 \ldots \ldots \ldots \ldots \ldots \ldots \ldots \ldots \ldots \ldots \ldots . . . . . .61$ 


\section{CONVERSION FACTORS AND VERTICAL DATUM}

\begin{tabular}{lcl}
\multicolumn{1}{c}{ Multiply } & By & To obtain \\
inch & 25.40 & millimeter \\
foot & 0.3048 & meter \\
mile & 1.609 & kilometer \\
cubic yard & 0.7646 & cubic meter \\
quart & 0.9464 & liter \\
gallon & 3.785 & liter \\
gallon per minute & 0.06309 & liter per second
\end{tabular}
follows:

Temperature in degrees Celsius $\left({ }^{\circ} \mathrm{C}\right)$ or degrees Fahrenheit $\left({ }^{\circ} \mathrm{F}\right)$ can be converted as

$$
\begin{aligned}
& { }^{\circ} \mathrm{F}=1.8\left({ }^{\circ} \mathrm{C}\right)+32 \\
& { }^{\circ} \mathrm{C}=5 / 9\left({ }^{\circ} \mathrm{F}-32\right)
\end{aligned}
$$

Sea level: In this report "sea level" refers to the National Geodetic Vertical Datum of 1929--a geodetic datum derived from a general adjustment of the first-order level nets of the United States and Canada, formerly called Sea Level Datum of 1929.

The use of trade names in this report is for identification purposes only and does not imply endorsement by the U.S. Geological Survey. 


\title{
HYDROGEOLOGY AND GROUND-WATER QUALITY OF THE CHROMIC ACID PIT SITE, U.S. ARMY AIR DEFENSE ARTILLERY CENTER AND FORT BLISS, EL PASO, TEXAS
}

\author{
By Cynthia G. Abeyta and Carole L. Thomas
}

\begin{abstract}
The Chromic Acid Pit site is an inactive waste disposal site that is regulated by the Resource Conservation and Recovery Act of 1976. The 2.2-cubic-yard cement-lined pit was operated from 1980 to 1983 by a contractor to the U.S. Army Air Defense Artillery Center and Fort Bliss. The pit, located on the Fort Bliss military reservation, in El Paso, Texas, was used for disposal and evaporation of chromic acid waste generated from chrome plating operations. The site was certified closed in 1989 and the Texas Natural Resources Conservation Commission issued Permit Number HW-50296 (U.S. Environmental Protection Agency Permit Number TX4213720101), which approved and implemented post-closure care for the Chromic Acid Pit site. In accordance with an approved post-closure plan, the U.S. Geological Survey is cooperating with the U.S. Army in evaluating hydrogeologic conditions and ground-water quality at the site. One upgradient and two downgradient ground-water monitoring wells were installed adjacent to the chromic acid pit by a private contractor. Quarterly ground-water sampling of these wells by the U.S. Geological Survey began in December 1993.

The Chromic Acid Pit site is situated in the Hueco Bolson intermontane valley. The Hueco Bolson is a primary source of ground water in the El Paso area. City of El Paso and U.S. Army water-supply wells are located on all sides of the study area and are completed 600 to more than 1,200 feet below land surface. The ground-water level in the area of the Chromic Acid Pit site has declined about 25 feet from 1982 to 1993. Depth to water at the Chromic Acid Pit site in September 1994 was about 284 feet below land surface; ground-water flow is to the southeast.

Ground-water samples collected from monitoring wells at the Chromic Acid Pit site contained dissolved-solids concentrations of 442 to 564 milligrams per liter. Nitrate as nitrogen concentrations ranged from 2.1 to 2.7 milligrams per liter; nitrite plus nitrate as nitrogen concentrations ranged from 2.3 to 3.0 milligrams per liter. Nitrate concentrations are abnormally high in the Old Mesa well field located about 5,000 feet southwest of the Chromic Acid Pit site. Volatile and semivolatile organic compounds in water samples were analyzed for the first sampling round; no confirmed volatile or semivolatile organic compounds were detected above the laboratory reporting limits. Total chromium concentrations ranged from 0.0099 to 0.092 milligram per liter; dissolved chromium concentrations ranged from 0.0068 to 0.0094 milligram per liter. Overall, water-quality characteristics in water from the chromic acid pit ground-water monitoring wells are similar to those in the surrounding area. Detected chemical concentrations in water from the chromic acid pit monitoring wells during the four sampling periods were below U.S. Environmental Protection Agency-established maximum contaminant levels for public drinking water supplies.

Statistical analyses were performed on 39 of the chemical constituents analyzed for in ground water from the chromic acid pit monitoring wells. Concentrations of chloride and fluoride were significantly less in water from the downgradient wells than in water from the upgradient well, whereas concentrations of nitrate as nitrogen, nitrite plus nitrate as nitrogen, and dissolved solids were significantly greater in water from the downgradient wells than in
\end{abstract}


water from the upgradient well. Concentrations of nitrate as nitrogen were significantly different in water from the two downgradient wells. Differences detected through statistical analysis of chemical constituents of water in the chromic acid pit monitoring wells did not appear to indicate a release of hazardous chemicals from the chromic acid pit. There was no indication of ground-water contamination in either downgradient well.

\section{INTRODUCTION}

The U.S. Army Air Defense Artillery Center and Fort Bliss (USAADACENFB) military reservation is located within the extraterritorial jurisdiction of the City of El Paso and extends into unincorporated parts of El Paso County, Texas, and the counties of Doña Ana and Otero in New Mexico (fig. 1). The primary missions of the USAADACENFB are air defense artillery training, senior noncommissioned officers training, administrative and logistical support of military tenant activities, and provision of training facilities for reserve components. With a total Post population of approximately 90,900 people (USAADACENFB, Population Performance Factors, March 1994, written commun., April 26, 1994), the USAADACENFB military reservation serves military and civilian personnel (17,900 and 7,900 people, respectively), on- and off-Post military family members $(8,400$ and 15,700 people, respectively), and retirees and retiree family members (14,500 and 26,500 people, respectively).

A government contractor for the USAADACENFB operated a Resource Conservation and Recovery Act of 1976 (RCRA)-regulated evaporation pit from 1980 to 1983. The contractor used the concrete-lined pit to reduce, by evaporation, the volume of chromic acid used by chrome plating operations. The Chromic Acid Pit site is located west of the Biggs Army Airfield main northeast/southwest runway, within the limits of the airfield in El Paso County, Texas (fig. 2). Chromic acid waste from a metal cleaning operation was disposed of in the concrete pit from 1980 to 1983 . The pit was approximately 2 feet deep by 18 inches wide by 20 feet long ( 2.2 cubic yards). The chromic acid pit is about 600 feet northwest of Building 11005, the nearest occupied structure (fig. 2). Access to the site is limited to authorized personnel only. No utilities are within the perimeter of the site.

The chromic acid pit was closed as a Class I industrial waste landfill according to the Chromic Acid Pit Closure Plan of January 7, 1987 (U.S. Army Air Defense Artillery Center and Fort Bliss, written commun., January 7, 1987). The closure plan called for the removal of contaminated soil below or adjacent to the lined pit until the "in situ" total chromium contamination level was less than 500 parts per million (ppm) and the extraction procedure (EP) toxicity chromium contamination level was less than $5.0 \mathrm{ppm}$. The Chromic Acid Pit site was reclaimed and covered with a clay cap. Closure was achieved according to the closure plan and certified closed by a professional engineer on April 6, 1989. On January 17, 1991, the Texas Water Commission (TWC, now called the Texas Natural Resources Conservation Commission (TNRCC)) issued U.S. Environmental Protection Agency (EPA) Permit No. TX4213720101 and TNRCC Permit No. HW-50296 (Texas Natural Resources Conservation Commission, written commun., January 1991), which among other things, approved and implemented post-closure care for the Chromic Acid Pit site.

In accordance with the post-closure plan (U.S. Army Air Defense Artillery Center and Fort Bliss, written commun., May 1990) the USAADACENFB is evaluating hydrogeologic conditions of the Chromic Acid Pit site to implement requirements of Federal and State of Texas regulatory programs. In 1993, the U.S. Geological Survey, in cooperation with the U.S. Army, initiated a study of the Chromic Acid Pit site to identify hydrogeologic conditions and ground-water quality at the facility. Results of this study will be used by the U.S. Army to aid in fulfilling regulatory requirements at the facility. 


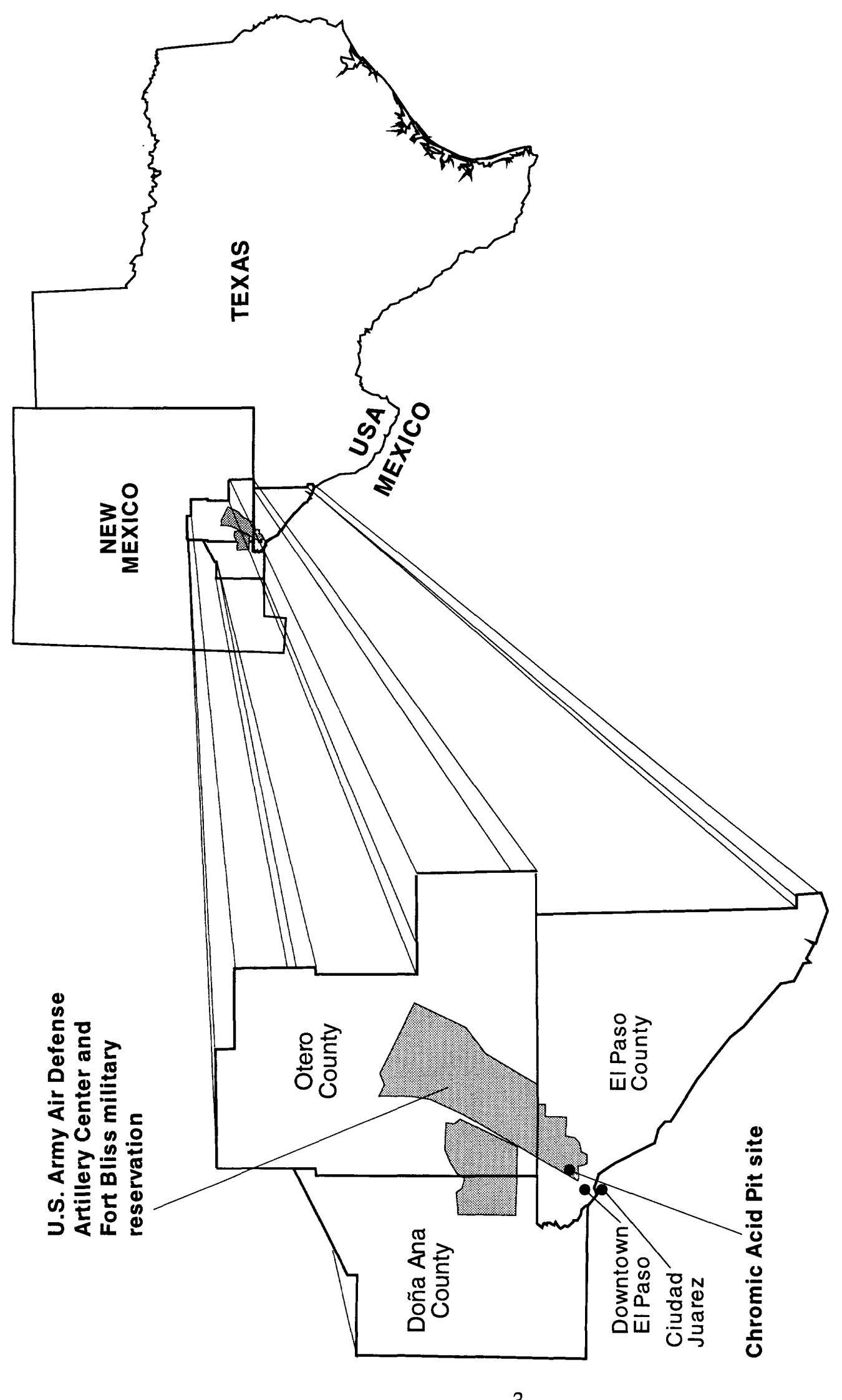

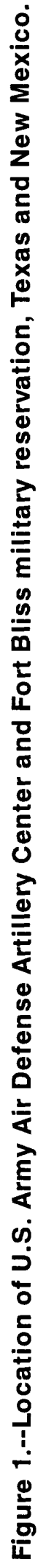




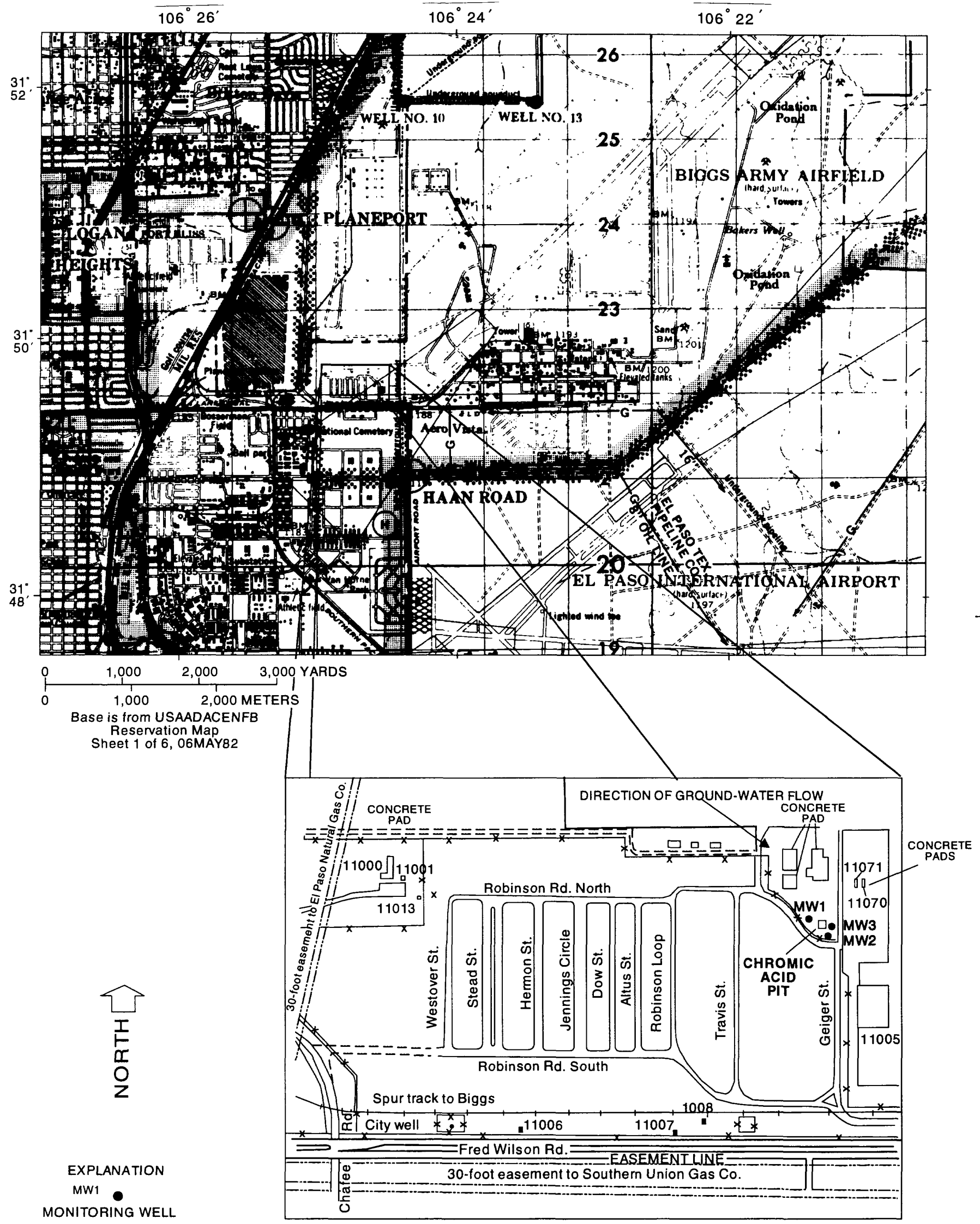

Figure 2.--Location of Chromic Acid Pit site and monitoring wells, U.S. Army Air Defense Artillery Center and Fort Bliss, EI Paso, Texas. 


\section{Purpose and Scope}

The primary objectives of this report are to: (1) present information on the environmental setting of the Chromic Acid Pit site and vicinity, including a description of the physiography, climate, and soils; (2) describe geologic and hydrologic characteristics of the unsaturated zone and shallow aquifer; and (3) describe the ground-water quality at the Chromic Acid Pit site. This compilation of data will result in a better understanding of the hydrogeology and ground-water quality at the Chromic Acid Pit site. The hydrogeology of the Chromic Acid Pit site is characterized on the basis of existing and new data collected since the initiation of this project in 1993. Water-quality data were obtained on a quarterly basis for ground-monitoring wells MW1, MW2, and MW3 located adjacent to the chromic acid pit. Data were collected in accordance with TNRCC approved plans and specifications to maintain a consistent monitoring program. These plans and specifications are described in the following documents:

1. Groundwater Sampling and Analysis Plan (U.S. Army Air Defense Artillery Center and Fort Bliss, written commun., May 1990),

2. Sampling and Analysis Plan for Chromic Acid Pit, U.S. Army Air Defense Artillery Center and Fort Bliss, El Paso, Texas, Draft 2 (U.S. Geological Survey, written commun., December 1993), and

3. Sampling and Analysis Plan for Chromic Acid Pit, U.S. Army Air Defense Artillery Center and Fort Bliss, El Paso, Texas, Final (U.S. Geological Survey, written commun., May 1994).

\section{Federal and State of Texas Regulatory Programs}

In June 1980 the Department of Defense (DOD) issued Defense Environmental Quality Program Policy Memorandum 80-6, which mandated that hazardous waste material sites on DOD installations be identified. DOD policy is to identify and evaluate suspected problems associated with past hazardous contamination and to control hazards to the public health and welfare. The USAADACENFB implemented the DOD mandate in February 1983 by initiating an Installation Restoration Program (IRP) to identify the location and contents of past hazardous material disposal or spill sites and to control hazards to public health and the environment. The IRP is the basis for response actions on DOD installations under the provisions of the Comprehensive Environmental Response, Compensation, and Liability Act (CERCLA) of 1980, the Superfund Amendment and Reauthorization Act (SARA) of 1986, the RCRA of 1976, the Hazardous and Solid Waste Amendments of 1984, and Executive Order 12316. The SARA confirms that CERCLA is applicable to Federal facilities and defines the process by which Federal agencies are required to initiate remedial actions at their facilities.

Previous IRP investigations at the USAADACENFB, in compliance with the above mandates, began with a USAADACENFB Headquarters installation assessment (Environmental Science and Engineering, Inc., 1983). The initial assessment was followed by an evaluation of solid waste management units (U.S. Army Environmental Hygiene Agency, 1987) and an RCRA Facility Assessment (RFA) (A.T. Kearney, Inc., 1989; U.S. Army Environmental Hygiene Agency, 1989; and Environmental Science and Engineering, Inc., 1991). Initial assessments included a literature search of published and unpublished reports, discussions with key installation personnel, examination of topographic maps and aerial photographs, identification of potentially hazardous sites, and initial assessments of those sites.

On January 17, 1991, a permit for industrial solid waste management for Class I hazardous waste storage, processing, and post-closure care at the USAADACENFB military reservation was issued by the TWC under provisions of the Texas Health and Safety Code Announcement, 
Chapter 361-Vernon. The permit is referred to as Texas Permit No. HW-50296/EPA Permit No. TX4213720101. Provisions in the permit stem from State and Federal authority and are subject to TNRCC rules and orders and Texas laws.

The permit authorized the USAADACENFB to perform post-closure care for the 2.2-cubicyard surface impoundment, identified as the chromic acid pit, according to the Chromic Acid Pit Post-Closure Care Plan of May 1990 (U.S. Army Air Defense Artillery Center and Fort Bliss, written commun., May 1990). The post-closure care plan called for routine maintenance of the site and ground-water monitoring activities. Routine maintenance inspections are conducted by USAADACENFB staff. Ground-water monitoring activities were initiated by construction of three monitoring wells, MW1, MW2, and MW3, installed by a private contractor and completed in July 1993 (fig. 2). These wells were installed in compliance with part 31 of the Texas Administrative Code, Section 335.163 (31 TAC 335.163). Well-completion diagrams for these wells are shown in figures 3, 4, and 5. The TNRCC inspected the successfully constructed monitoring wells in July 1993.

\section{Ground-Water Sampling and Analysis Plan}

Ground-water sampling was initiated with the submittal of a detailed site-specific Sampling and Analysis Plan (SAP) (Sampling and Analysis Plan for Chromic Acid Pit, U.S. Army Air Defense Artillery Center and Fort Bliss, El Paso, Texas, Draft 2, U.S. Geological Survey, written commun., December 1993) by the USAADACENFB in draft form to the TNRCC in December 1993. This draft SAP is a supplement to the approved May 1990 Sampling and Analysis Plan (Attachment C of TNRCC Permit No. HW-50296, written commun., January 1991). The draft SAP identifies constituents to be analyzed for (table 1) in accordance with Section III.D.3 of TNRCC Permit No. HW-50296.

The first round of quarterly sampling at the Chromic Acid Pit site was conducted in December 1993. Ground-water samples were collected and analyzed according to specifications identified in the draft SAP. Ground-water samples were analyzed for alkalinity, specific conductance, $\mathrm{pH}$, temperature, turbidity, dissolved solids, suspended solids, common anions, nitrates, total petroleum hydrocarbons, chromium, hexavalent chromium, and constituents listed in Appendix IX (U.S. Environmental Protection Agency, 1993, Appendix IX), including volatile organic compounds, semivolatile organic compounds, and metals (table 1).

After review of the results of the first sampling round and final review of the draft SAP (U.S. Geological Survey, written commun., December 1993) by the TNRCC, a new list of constituents for analysis was recommended for detection monitoring (Texas Natural Resources Conservation Commission, written commun., January 24, 1994). The new list is in the final TNRCC-approved SAP (U.S. Geological Survey, written commun., May 1994) and includes alkalinity, specific conductance, $\mathrm{pH}$, temperature, turbidity, dissolved solids, suspended solids, common ions, nitrates, chromium, metals, total organic carbon, and total organic halides (table 2). Analysis of total petroleum hydrocarbons was also recommended by the TNRCC for the first year of ground-water monitoring (Mark Arthur, Texas Natural Resources Conservation Commission; Yvette McKenna, U.S. Army Air Defense Artillery Center and Fort Bliss; and Cynthia Abeyta, U.S. Geological Survey, oral commun., February 22, 1994). 


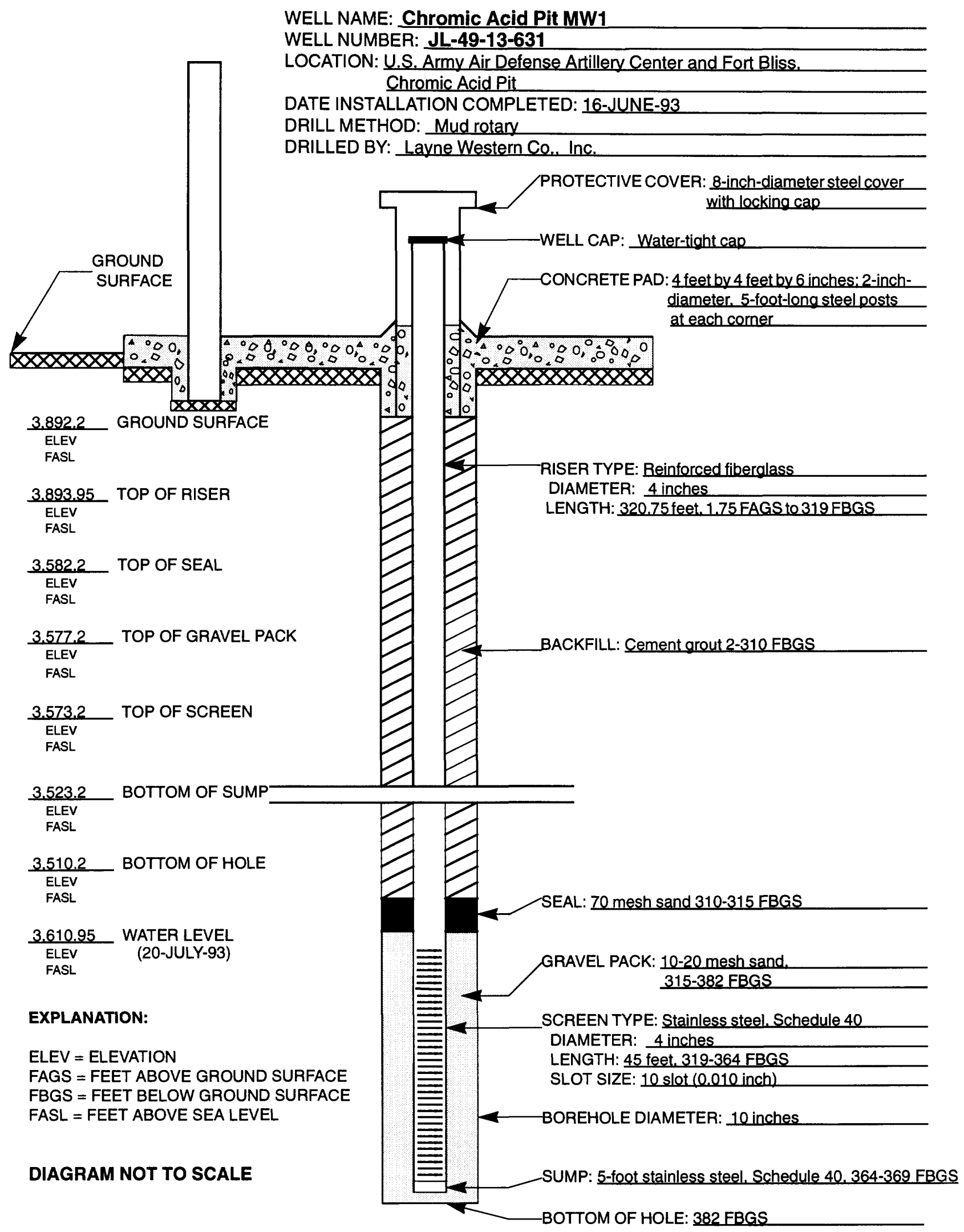

Figure 3.--Well completion of Chromic Acid Pit ground-water monitoring well MW1. 


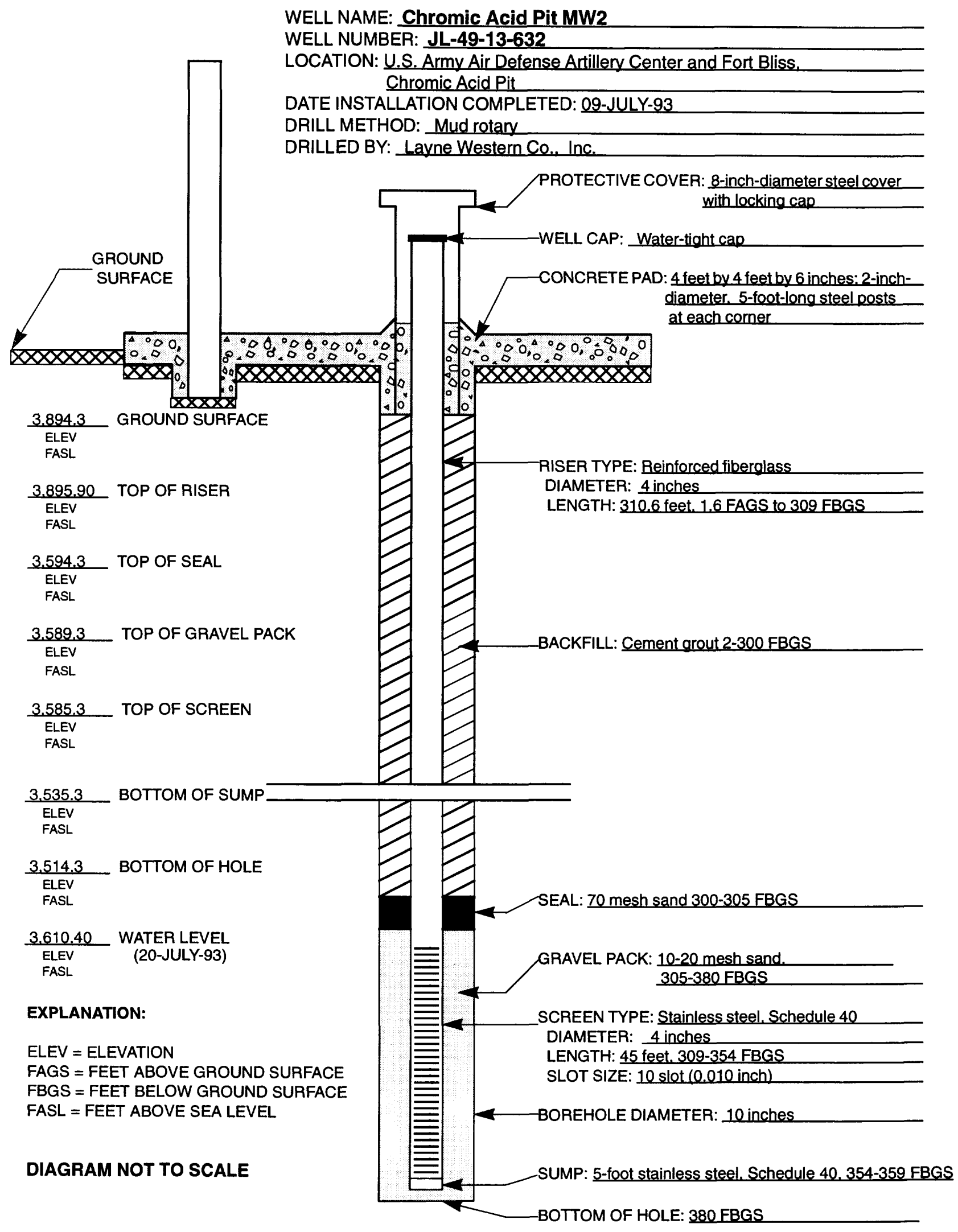

Figure 4.--Well completion of Chromic Acid Pit ground-water monitoring well MW2. 


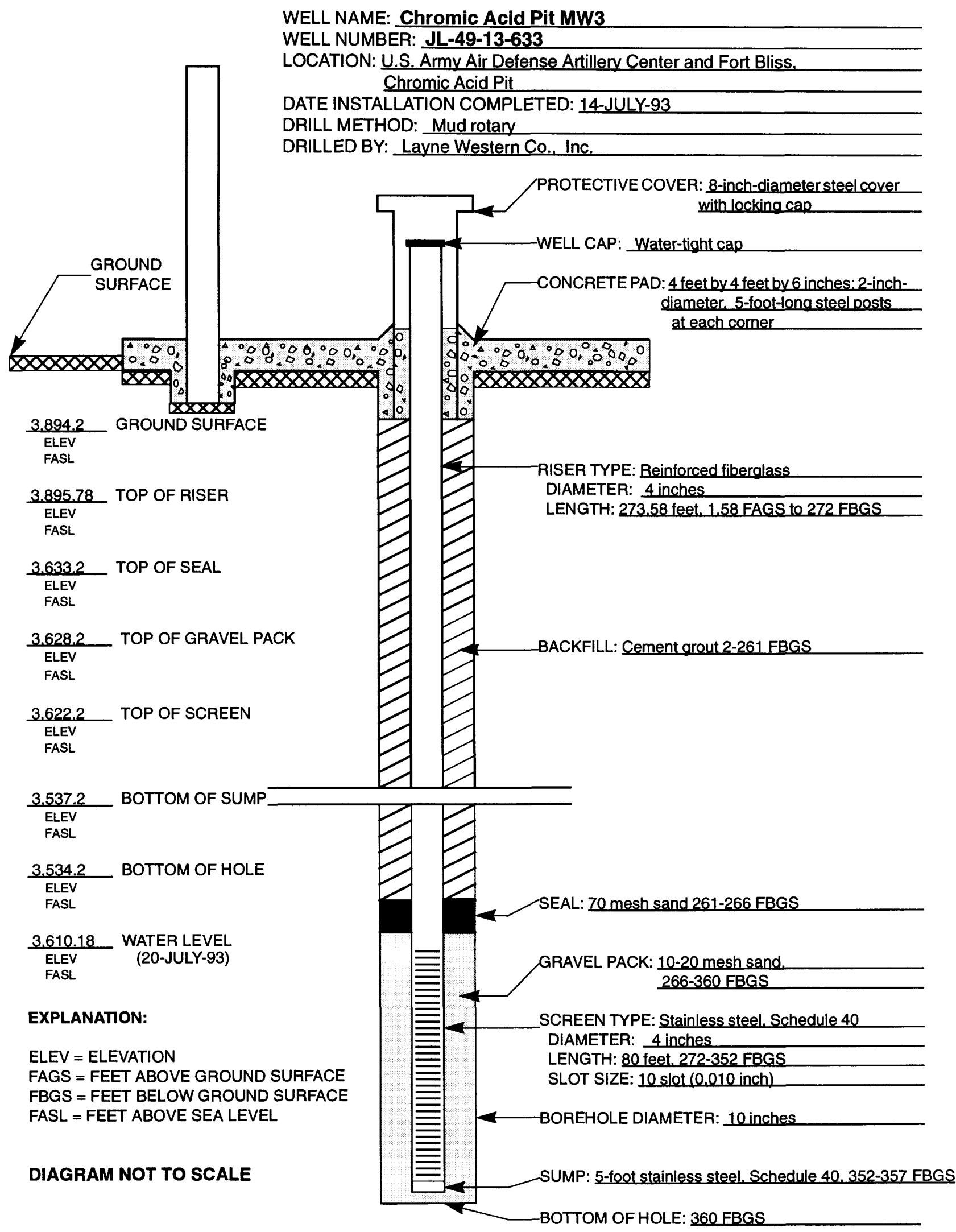

Figure 5.--Well completion of Chromic Acid Pit ground-water monitoring well MW3. 
Table 1.--Analytical constituents and methods used for ground-water monitoring at the Chromic Acid Pit site, December 1993

\begin{tabular}{|c|c|}
\hline Constituent and unit & Method number ${ }^{1}$ \\
\hline \multicolumn{2}{|l|}{ Field tests: } \\
\hline Temperature, degrees Celsius & E170.1 \\
\hline Turbidity, nephelometric turbidity units & E180.1 \\
\hline $\mathrm{pH}$, standard units & E150.1 \\
\hline $\begin{array}{l}\text { Specific conductance, microsiemens per centimeter } \\
\text { at } 25 \text { degrees Celsius }\end{array}$ & E120.1 \\
\hline $\begin{array}{l}\text { Alkalinity - carbonate, bicarbonate, calcium } \\
\text { carbonate, milligrams per liter }\end{array}$ & A403 \\
\hline Dissolved solids, milligrams per liter & E160.1 \\
\hline Suspended solids, milligrams per liter & E160.2 \\
\hline $\begin{array}{l}\text { Common anions: chloride, fluoride, sulfate, } \\
\text { milligrams per liter }\end{array}$ & E300 \\
\hline Nitrite plus nitrate as nitrogen, milligrams per liter & E353.2 \\
\hline Chromium (total and dissolved), milligrams per liter & SW3020/SW7191 and SW3005/SW7191 \\
\hline $\begin{array}{l}\text { Chromium - hexavalent, total and dissolved, milli- } \\
\text { grams per liter }\end{array}$ & SW7196 \\
\hline Total petroleum hydrocarbons, micrograms per liter & E418.1 \\
\hline \multicolumn{2}{|l|}{ Appendix IX constituents: } \\
\hline \multicolumn{2}{|l|}{ Metals: } \\
\hline $\begin{array}{l}\text { Antimony, barium, beryllium, cadmium, } \\
\text { chromium, cobalt, copper, nickel, silver, tin, } \\
\text { vanadium, zinc (total and dissolved), milligrams } \\
\text { per liter }\end{array}$ & SW6010 \\
\hline Arsenic (total and dissolved), milligrams per liter & SW7060 \\
\hline Lead (total and dissolved), milligrams per liter & SW7421 \\
\hline Mercury (total and dissolved), milligrams per liter & SW7470 \\
\hline Selenium (total and dissolved), milligrams per liter & SW7740 \\
\hline Thallium (total and dissolved), milligrams per liter & SW7841 \\
\hline Cyanide, milligrams per liter & SW9010 \\
\hline Sulfide, milligrams per liter & SW9030 \\
\hline Volatile organic compounds, micrograms per liter & SW8240 \\
\hline Semivolatile organic compounds, micrograms per liter & SW3510/SW8270 \\
\hline
\end{tabular}

${ }^{1}$ Method numbers preceded by $\mathrm{A}$ are from:

Standard methods for the examination of water and wastewater, 16th edition (American Public Health Association and others, 1985).

Method numbers preceded by $\mathrm{E}$ are from:

Methods for chemical analysis of water and wastes, EPA Manual 600/4-79-020 (U.S. Environmental Protection Agency, 1983 - with additions),

Inductively coupled plasma-atomic emission spectrometer method for trace element analysis of water and wastes, 40CFR 261, Appendix C (U.S. Environmental Protection Agency, 1986a), and Methods for organic chemical analysis of municipal and industrial wastewater, 40CFR 136, Appendix A (U.S. Environmental Protection Agency, 1986b).

Method numbers preceded by SW are from:

Test methods for evaluating solid waste, physical/chemical methods, SW-846, $3 \mathrm{~d}$ edition (U.S. Environmental Protection Agency, 1986c). 
Table 2.--Analytical constituents and methods used for quarterly ground-water monitoring at the Chromic Acid Pit site subsequent to December 1993

\begin{tabular}{|c|c|}
\hline Constituent and unit & Method number ${ }^{1}$ \\
\hline \multicolumn{2}{|l|}{ Field tests: } \\
\hline Temperature, degrees Celsius & E170.1 \\
\hline Turbidity, nephelometric turbidity units & E180.1 \\
\hline $\mathrm{pH}$, standard units & E150.1 \\
\hline $\begin{array}{l}\text { Specific conductance, microsiemens per centimeter } \\
\text { at } 25 \text { degrees Celsius }\end{array}$ & E120.1 \\
\hline $\begin{array}{l}\text { Alkalinity - carbonate, bicarbonate, calcium } \\
\text { carbonate, milligrams per liter }\end{array}$ & A403 \\
\hline Dissolved solids, milligrams per liter & E160.1 \\
\hline Suspended solids, milligrams per liter & E160.2 \\
\hline $\begin{array}{l}\text { Common anions: chloride, fluoride, nitrate, } \\
\text { orthophosphate, sulfate, milligrams per liter }\end{array}$ & E300 or $\mathrm{A} 429$ \\
\hline $\begin{array}{l}\text { Cations: calcium, magnesium, potassium, sodium } \\
\text { (total and dissolved), milligrams per liter }\end{array}$ & SW6010 \\
\hline Nitrite plus nitrate as nitrogen, milligrams per liter & E353.2 \\
\hline \multicolumn{2}{|l|}{ Metals: } \\
\hline $\begin{array}{l}\text { Aluminum, antimony, arsenic, barium, beryllium, } \\
\text { cadmium, cobalt, copper, iron, lead, manganese, } \\
\text { molybdenum, nickel, selenium, silver, thallium, } \\
\text { vanadium, zinc (total and dissolved), milligrams } \\
\text { per liter }\end{array}$ & SW6010 \\
\hline $\begin{array}{l}\text { Chromium (total and dissolved), milligrams per } \\
\text { liter }\end{array}$ & SW7191 \\
\hline Total organic carbon, milligrams per liter & SW9060 \\
\hline Total organic halides, micrograms per liter & SW9020 \\
\hline
\end{tabular}

${ }^{1}$ Method numbers preceded by $A$ are from:

Standard methods for the examination of water and wastewater, 16th edition (American Public Health Association and others, 1985).

Method numbers preceded by $\mathrm{E}$ are from:

Methods for chemical analysis of water and wastes, EPA Manual 600/4-79-020 (U.S. Environmental Protection Agency, 1983 - with additions),

Inductively coupled plasma-atomic emission spectrometer method for trace element analysis of water and wastes, 40CFR 261, Appendix C (U.S. Environmental Protection Agency, 1986a), and Methods for organic chemical analysis of municipal and industrial wastewater, 40CFR 136,

Appendix A (U.S. Environmental Protection Agency, 1986b).

Method numbers preceded by SW are from:

Test methods for evaluating solid waste, physical/chemical methods, SW-846, 3d edition (U.S.

Environmental Protection Agency, 1986c). 


\section{Well-Numbering System}

The well-numbering system in Texas was developed by the Texas Water Development Board for use throughout the State (fig. 6). The well number is divided into five segments; in this report the first four segments are divided by hyphens. The first segment is a two-letter prefix that identifies the county. The second segment indicates a 1-degree quadrangle that is given a number consisting of two digits ranging from 01 to 89; this two-digit number is indicated by the third and fourth digits of the well number. Each 1-degree quadrangle is divided into 7.5-minute quadrangles that are given a two-digit number from 01 to 64; this two-digit number is the third segment of the well number and is indicated by the fifth and sixth digits. Each 7.5-minute quadrangle is divided into 2.5-minute quadrangles that are given a single-digit number from 1 to 9; this one-digit number is the fourth segment of the well number and is indicated by the seventh digit. Finally, each well within a 2.5-minute quadrangle is given a two-digit number in the order in which it was inventoried, starting with 01; this two-digit number is the fifth segment of the well number. All wells referred to in this report are located on the U.S. Geological Survey El Paso 7.5-minute quadrangle.

\section{ENVIRONMENTAL SETTING}

The Fort Bliss Post Headquarters and Chromic Acid Pit site are within the extraterritorial jurisdiction of the City of El Paso (fig. 7). The population of the El Paso metropolitan area is greater than 600,000 (Hispano Chamber of Commerce, El Paso, Texas, oral commun., 1994). Ciudad Juarez, Mexico, lies directly south of El Paso across the Rio Grande and has a population greater than 1,000,000 (Hispano Chamber of Commerce, El Paso, Texas, oral commun., 1994).

\section{Physiography}

Fort Bliss military reservation lies in the Hueco Bolson intermontane valley (fig. 7). The Hueco Bolson intermontane valley was produced by numerous diverse faults and folds and is divided into two distinct parts. The northern extension of the Hueco Bolson is referred to as the Tularosa Basin; the southern extension is referred to as the Hueco Bolson proper. The Tularosa Basin and Hueco Bolson are divided indefinitely a few miles north of the New Mexico-Texas border. The Tularosa Basin has no external drainage; the Hueco Bolson is partly drained by the Rio Grande. Elevations of the Fort Bliss military reservation range from 3,800 feet to more than 8,000 feet above sea level. The chromic acid pit is 2.5 miles east of the rugged Franklin Mountains. The Franklin Mountains have peaks from 4,600 to greater than 7,000 feet above sea level.

\section{Climate}

The climate of the Chromic Acid Pit site and vicinity, classified as arid continental, is characterized by an abundance of sunny days, high summer temperatures, relatively cool winters typical of arid areas, scanty rainfall, and very low humidity throughout the year. Temperature and precipitation data are recorded at El Paso International Airport by the National Weather Service and reported in monthly and annual reports by the National Oceanic and Atmospheric Administration. El Paso International Airport is approximately 3 miles southeast of the Chromic Acid Pit site (fig. 2). 

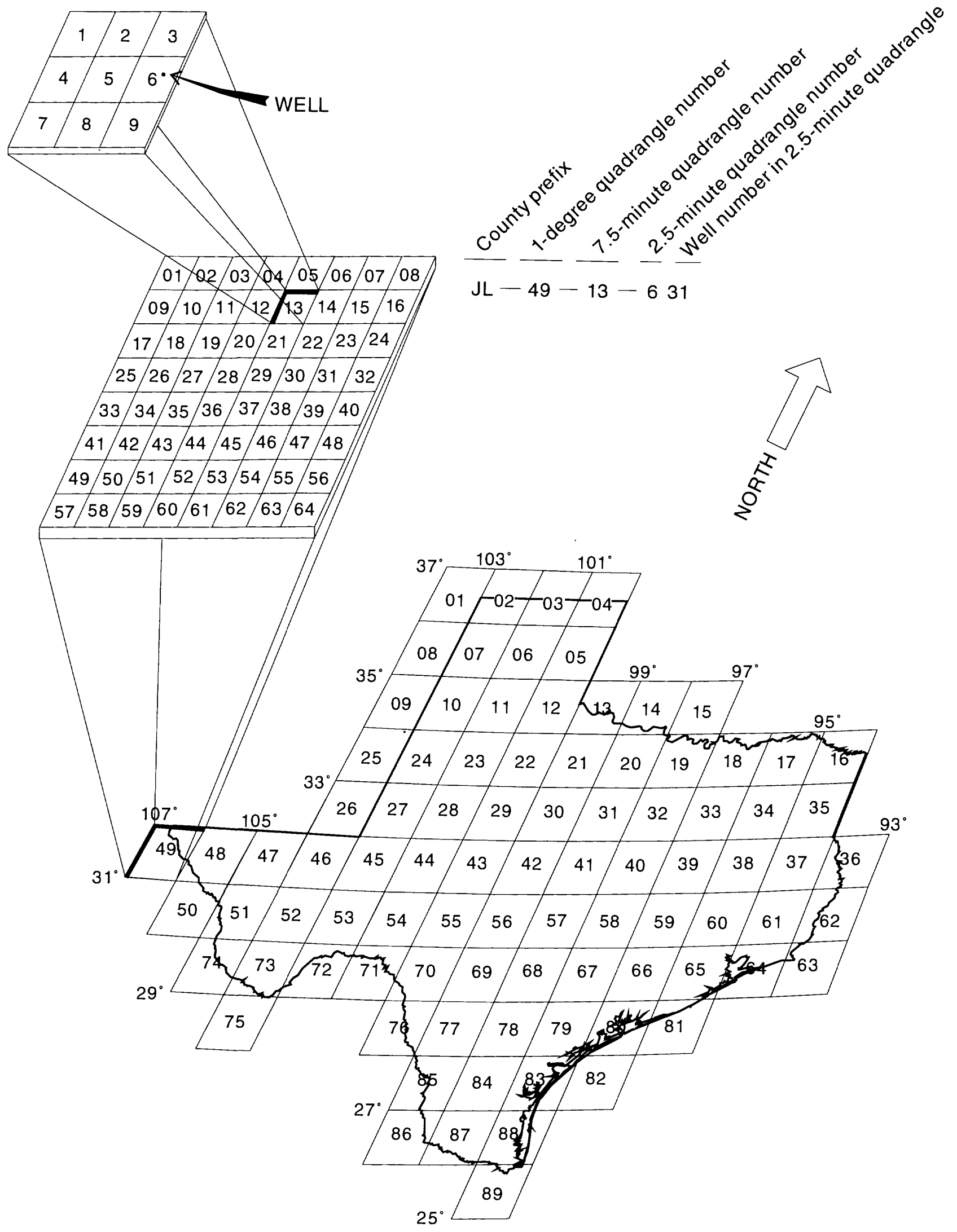

Figure 6.--Texas well-numbering system. 


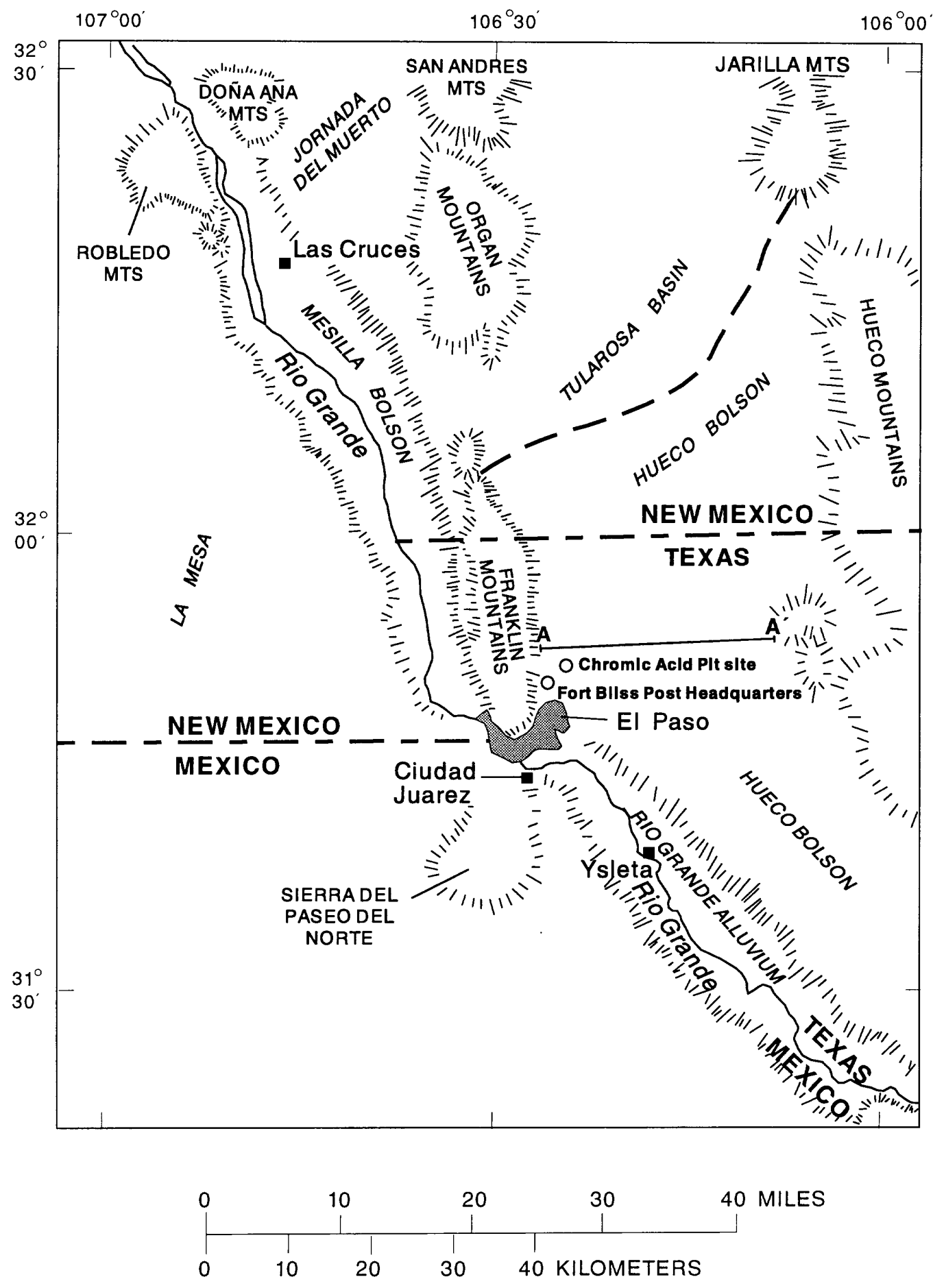

Figure 7.--Physiographic structures of the Tularosa Basin and Hueco Bolson (modified from Sayre and Livingston, 1945). See figures 8 and 17 for explanation of section A-A'. 
Mean annual precipitation in the El Paso area is 7.8 inches (U.S. Department of Commerce, National Oceanic and Atmospheric Administration, 1992). Average monthly precipitation ranges from less than 1 inch during October through June to more than 1.2 inches in July, August, and September. Winter months are typically dry, and monthly snowfalls seldom exceed 3 inches (approximately 0.25 inch of water). Snow rarely lasts longer than 24 hours in the nonmountainous areas. Typically rainy months receive almost half of the annual precipitation in the form of brief but locally heavy thunderstorms. Prolonged periods of continuous precipitation are rare.

Average annual temperature at $\mathrm{El}$ Paso International Airport is $63.3^{\circ} \mathrm{F}$, ranging from a mean monthly low of $44.2^{\circ} \mathrm{F}$ in January to a mean monthly high of $82.5^{\circ} \mathrm{F}$ in July (U.S. Department of Commerce, National Oceanic and Atmospheric Administration, 1992). Summer daytime temperatures are frequently above $90^{\circ} \mathrm{F}$ and occasionally rise above $100^{\circ} \mathrm{F}$. Summer night minimum temperatures are usually 60 to $65^{\circ} \mathrm{F}$. Winter days are cool and mild with temperatures rising to 55 to $60^{\circ} \mathrm{F}$. Winter night temperatures drop to below freezing during several nights in December and January.

The prevailing wind direction in the winter months is from the north and in the summer months is from the south. Dust and wind storms are frequent in March and April, and wind speeds occasionally exceed 35 miles per hour.

Evaporation records from a class A evaporation pan at Ysleta, Texas (fig. 7), for 1985-92 are given in table 3. Ysleta, Texas, is located in El Paso County southeast of El Paso and 15 miles southeast of the Chromic Acid Pit site. Average annual pan evaporation for 1985-92 was about 93 inches. Sixty-one percent of evaporation occurred during April through August. Potential evaporation is calculated using the pan evaporation figure and the conservative factor of 0.70 , resulting in an estimate of 65 inches per year.

\section{$\underline{\text { Soils }}$}

Soils of El Paso County, described by Jaco (1971), constitute generally the first 5 feet of unconsolidated material below land surface. The following is a description of soils at and adjacent to the chromic acid pit as described by Jaco. The soil descriptions are not applicable to the deeper part of the unsaturated zone (Hueco Bolson) through which potential contaminants would migrate toward the water table. Because soils do provide much of the material readily available for engineering purposes, however, estimated engineering properties (Jaco, 1971) are shown in table 4 for each soil series.

Soils on the Chromic Acid Pit site are identified as Turney-Berino Association (Jaco, 1971). Soils of the Turney-Berino Association, described as nearly level to gently sloping, have a clay loam subsoil and are moderately deep over soft caliche. Loam denotes a mixture of clay ( 7 to 27 percent), silt (28 to 50 percent), and sand (less than 52 percent). The following is a brief description of the Turney-Berino Association including the percentages of each series (Jaco, 1971):

TBB--Turney-Berino Association, undulating--includes Turney and Berino soils.

In El Paso County, the Turney-Berino Association constitutes 5 percent of the soils. Turney soils constitute 68 percent of the association, Berino soils constitute 18 percent, and minor soils constitute 14 percent.

Turney soils--typically have a moderately alkaline, calcareous surface layer about 10 inches thick. They are light-reddish-brown, fine sandy loam to a depth of about 3 inches and are light-brown loam below. The subsoil is light-brown, calcareous clay loam. Depth to soft caliche is about 34 inches.

Berino soils--are similar to Turney soils but their surface layer is noncalcareous and mildly alkaline, and their clay loam subsoil contains clay films on the soil particles. 


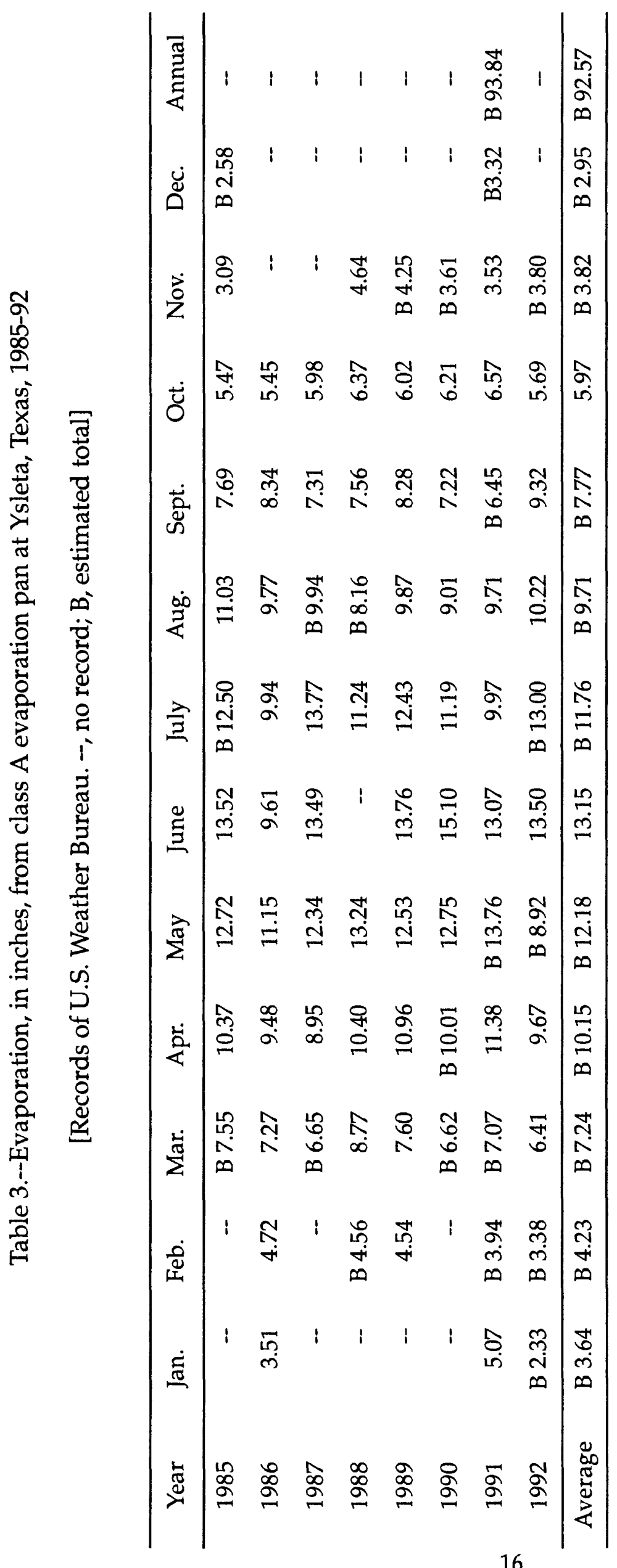




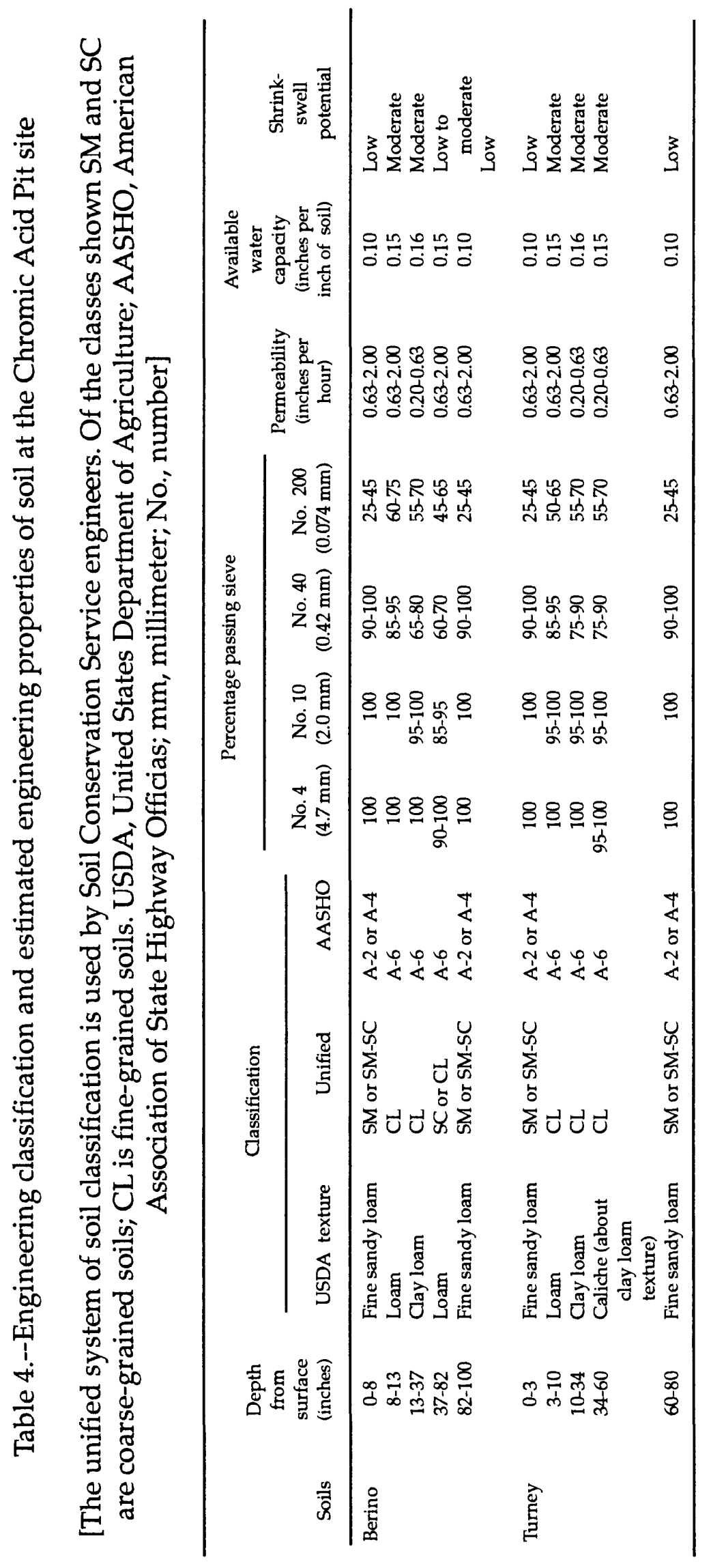




\section{HYDROGEOLOGY}

Data describing the hydrogeologic characteristics of the Chromic Acid Pit site were compiled from existing sources, during initial implementation of this study, and during quarterly ground-water monitoring. Existing hydrogeologic data specific to the Chromic Acid Pit site include data collected during installation of the chromic acid pit ground-water monitoring network. Data collected during the initial implementation of this study include geophysical logs and downhole camera visual analysis of the ground-water monitoring wells. Water-quality data collection for the first year of quarterly ground-water monitoring at the Chromic Acid Pit site began December 1993 and ended September 1994. A summary of the information available on the hydrogeology of the Chromic Acid Pit site and vicinity is presented in the following sections.

\section{Geology}

The Chromic Acid Pit site is underlain by Hueco Bolson deposits of locally derived materials. The Hueco Bolson is a clastic-filled graben extending from a few miles north of the New Mexico-Texas border to several miles south into Mexico (fig. 7). Hueco Bolson deposits are of Tertiary age and primarily include fluvial and lacustrine deposits, but alluvial-fan material and aeolian sediments also are present (Cliett, 1969). Hueco Bolson deposits are reported to have a maximum thickness of about 9,000 feet within a deep structural trough (fig. 8) paralleling the east base of the Franklin Mountains (Mattick, 1967, p. 85-91).

Hueco Bolson deposits typically are composed of fine- to medium-grained sand with interbedded lenses of clay, silt, gravel, and caliche. These deposits range from unconsolidated to slightly consolidated. Sand fragments are composed primarily of chert, granite, and porphyry. Individual beds are not well defined and range in thickness from a fraction of an inch to about 100 feet.

Consolidated igneous and sedimentary rocks ranging in age from Precambrian to Tertiary are exposed in the Franklin and Hueco Mountains (fig. 7). Igneous rocks are predominately granitic and are composed of coarse grains of quartz and feldspar. These granitic rocks are easily weathered and are a primary source material of the bolson deposits.

Chromic Acid Pit ground-water monitoring wells were installed by a private contractor contracted by the USAADACENFB and were completed June-July 1993. Driller's logs of lithologies penetrated during drilling of monitoring wells MW1, MW2, and MW3 are shown in tables 5, 6, and 7, respectively. Sediment types described in the driller's logs are systematically grouped into broad categories. Compound descriptions such as sand and clay are assumed to be 50 percent sand beds and 50 percent clay beds for the described interval. Other compound descriptions such as sandy clay are assumed to be 25 percent sand and 75 percent clay mixture for the described interval; similarly, clayey sand is assumed to be 25 percent clay and 75 percent sand.

Geophysical logs were run in each of the three cased Chromic Acid Pit site ground-water monitoring wells. Geophysical logs analyzed included gamma ray, neutron, gamma gamma, and caliper. These logs were used to evaluate well integrity, lithology, and formation saturation. On the basis of interpretation of geophysical logs and driller's lithologic descriptions, sedimentary material penetrated by the chromic acid pit wells was grouped into two broad categories: sand or gravel with small amounts of clay and silt, or clay or silt with small amounts of sand and gravel. The interpreted lithologic sections are shown in figures 9, 10, and 11.

The lithologic sections indicate that the Hueco Bolson below the Chromic Acid Pit site consists of alternating sand and gravel and clay and silt lenses with gradational zones of clayey sand, sandy clay, and sandy silty clay zones. Thirteen clayey and silty zones were penetrated in well MW1, 12 in MW2, and 13 in MW3. Thickness of clayey zones ranges from 2 to 16 feet. 


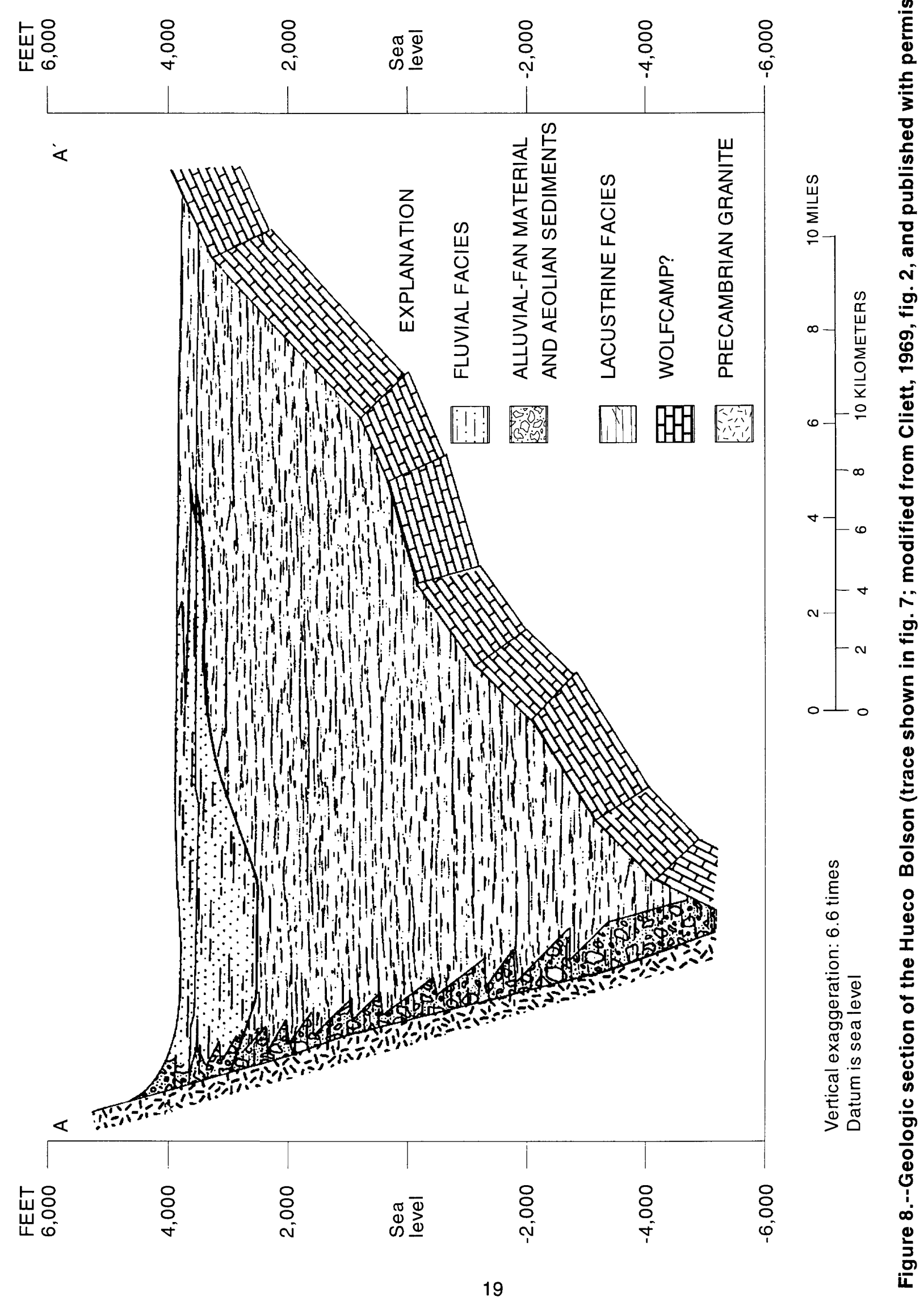


Table 5.-Driller's log of material penetrated by Chromic Acid Pit borehole MW1

\begin{tabular}{rcl}
\hline $\begin{array}{c}\text { Depth below } \\
\text { land surface } \\
\text { (feet) }\end{array}$ & $\begin{array}{c}\text { Thickness } \\
\text { (feet) }\end{array}$ & \multicolumn{1}{c}{ Description } \\
\hline $0-3$ & 3 & Top soil/fill \\
$3-10$ & 7 & Soft caliche \\
$10-50$ & 40 & Sand and gravel \\
$50-70$ & 20 & Clay \\
$70-90$ & 20 & Clay, minor sand \\
& & \\
$90-100$ & 10 & Sand \\
$100-110$ & 10 & Clay, sand \\
$110-130$ & 20 & Clay, silty sand \\
$130-145$ & 15 & Sand \\
$145-160$ & 15 & Clay and sand \\
$160-190$ & 30 & Sand \\
$190-230$ & 40 & Clay \\
$230-250$ & 20 & Gravel and sand \\
$250-270$ & 20 & Sandy clay \\
$270-280$ & 10 & Clay and minor sand \\
$280-310$ & 30 & \\
$310-340$ & 30 & Sand and minor clay \\
$340-350$ & 10 & Sandy clay \\
$350-377$ & 27 & Sand and gravel \\
$377-382$ & 5 & Sandy silty clay \\
\hline
\end{tabular}


Table 6.--Driller's log of material penetrated by Chromic Acid Pit borehole MW2

\begin{tabular}{rcl}
\hline $\begin{array}{c}\text { Depth below } \\
\text { land surface } \\
\text { (feet) }\end{array}$ & $\begin{array}{c}\text { Thickness } \\
\text { (feet) }\end{array}$ & \multicolumn{1}{c}{ Description } \\
\hline $0-3$ & 3 & Top soil/fill \\
$3-10$ & 7 & Soft caliche \\
$10-65$ & 55 & Sand and minor gravel \\
$65-70$ & 5 & Sand and gravel \\
$70-90$ & 20 & Clay and sand \\
$90-130$ & 40 & Sand and clay \\
$130-145$ & 15 & Sand \\
$145-160$ & 15 & Clay and sand \\
$160-190$ & 30 & Sandy clay \\
$190-220$ & 30 & Clay \\
$220-250$ & 30 & Sand and gravel \\
$250-280$ & 30 & Clay and sand \\
$280-340$ & 60 & Sandy clay \\
$340-360$ & 20 & Clay sand \\
$360-380$ & 20 & Clay \\
& & \\
\hline
\end{tabular}

Table 7.--Driller's log of material penetrated by Chromic Acid Pit borehole MW3

\begin{tabular}{ccl}
\hline $\begin{array}{c}\text { Depth below } \\
\text { land surface } \\
\text { (feet) }\end{array}$ & $\begin{array}{c}\text { Thickness } \\
\text { (feet) }\end{array}$ & \multicolumn{1}{c}{ Description } \\
\hline $0-3$ & 3 & Top soil/fill \\
$3-10$ & 7 & Soft caliche \\
$10-65$ & 55 & Sand, minor gravel \\
$65-70$ & 5 & Sand and gravel \\
$70-90$ & 20 & Clay and sand \\
$90-130$ & 40 & Sand and clay \\
$130-145$ & 15 & Sand \\
$145-160$ & 15 & Clay and sand \\
$160-190$ & 30 & Sandy clay \\
$190-220$ & 30 & Clay \\
$220-250$ & 30 & Sand and gravel \\
$250-280$ & 30 & Clay and sand \\
$280-340$ & 60 & Sandy clay \\
$340-360$ & 20 & Clayey sand \\
\hline
\end{tabular}




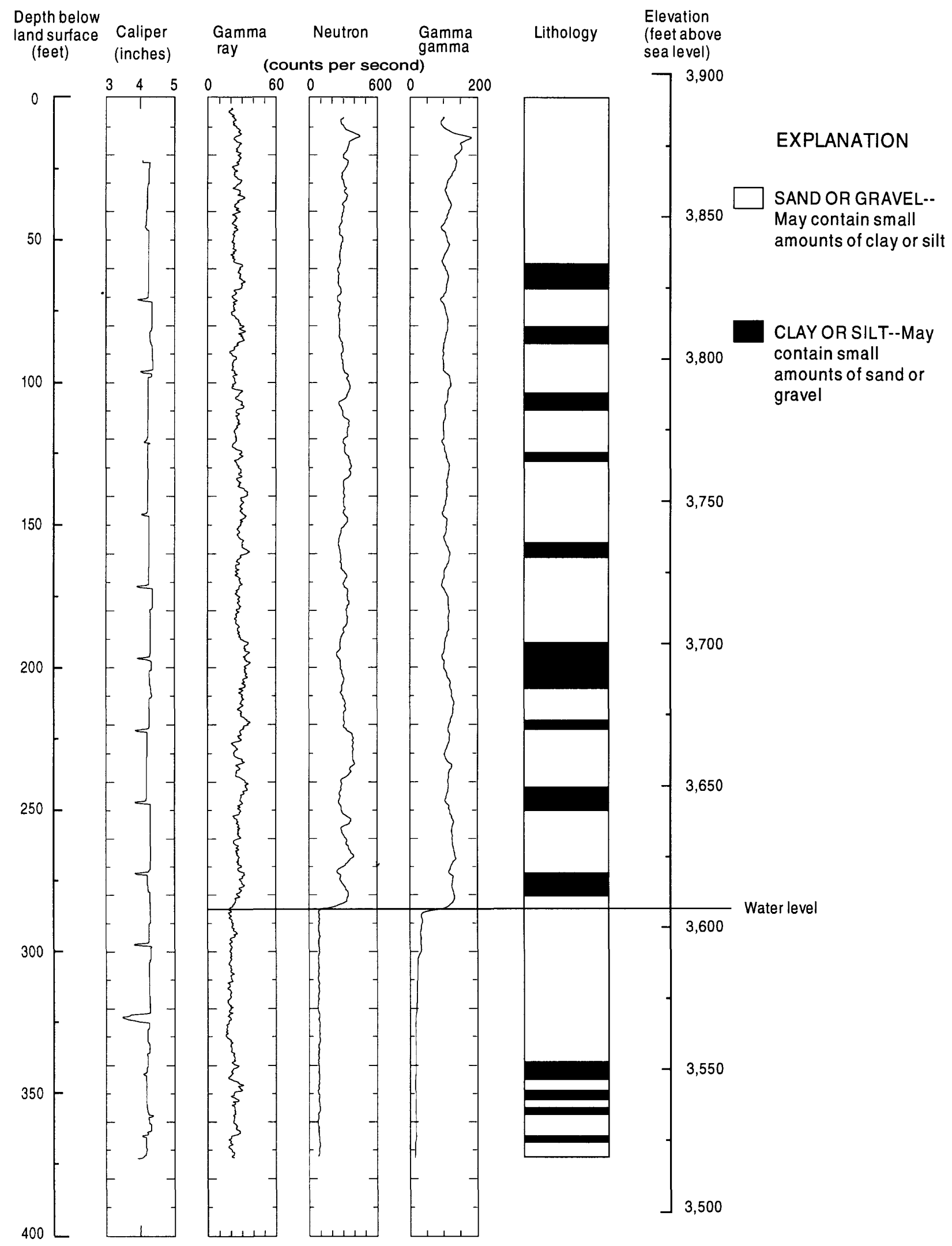

Figure 9.--Geophysical logs and interpreted lithologies at Chromic Acid Pit monitoring well MW1. 


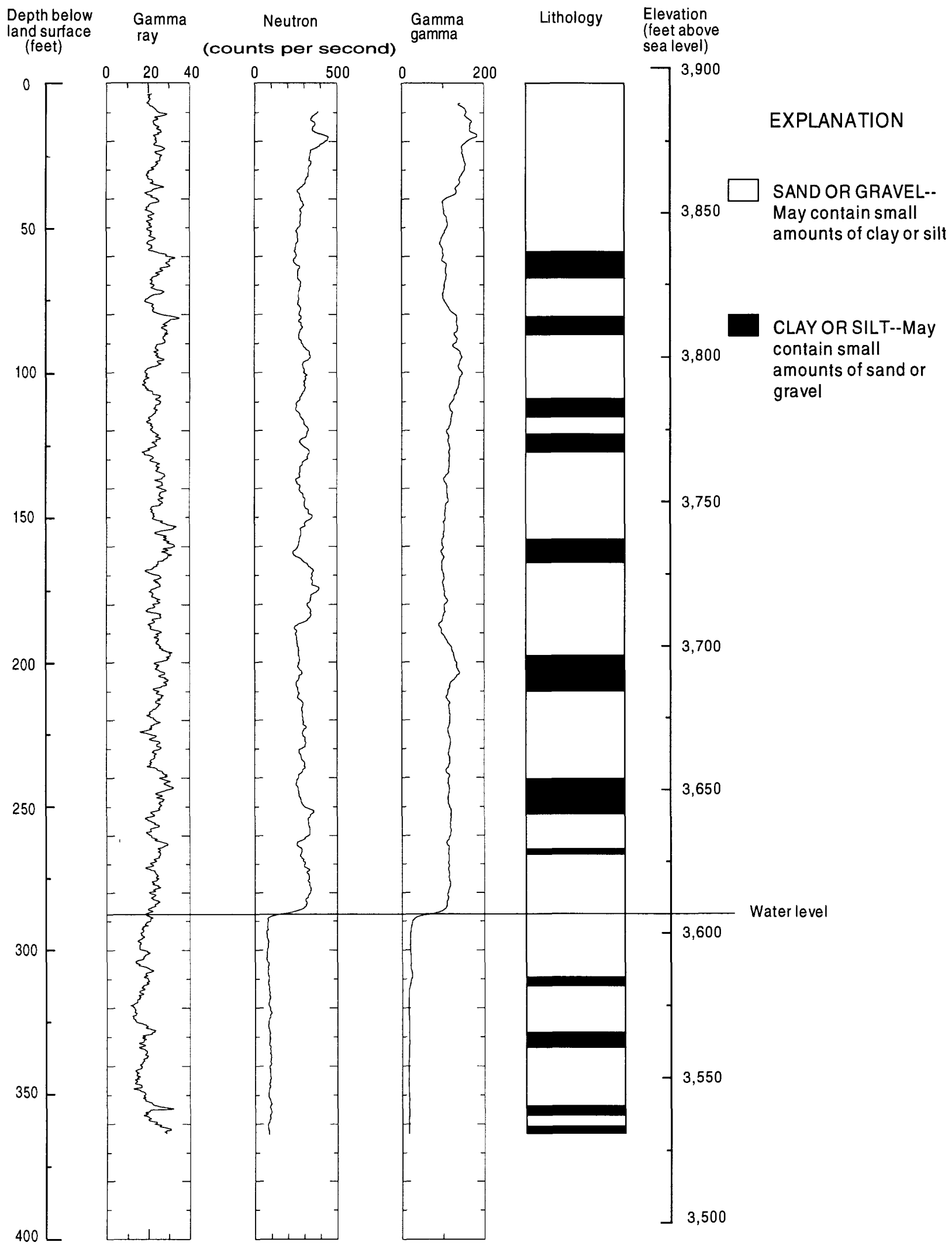

Figure 10.--Geophysical logs and interpreted lithologies at Chromic Acid Pit monitoring well MW2. 


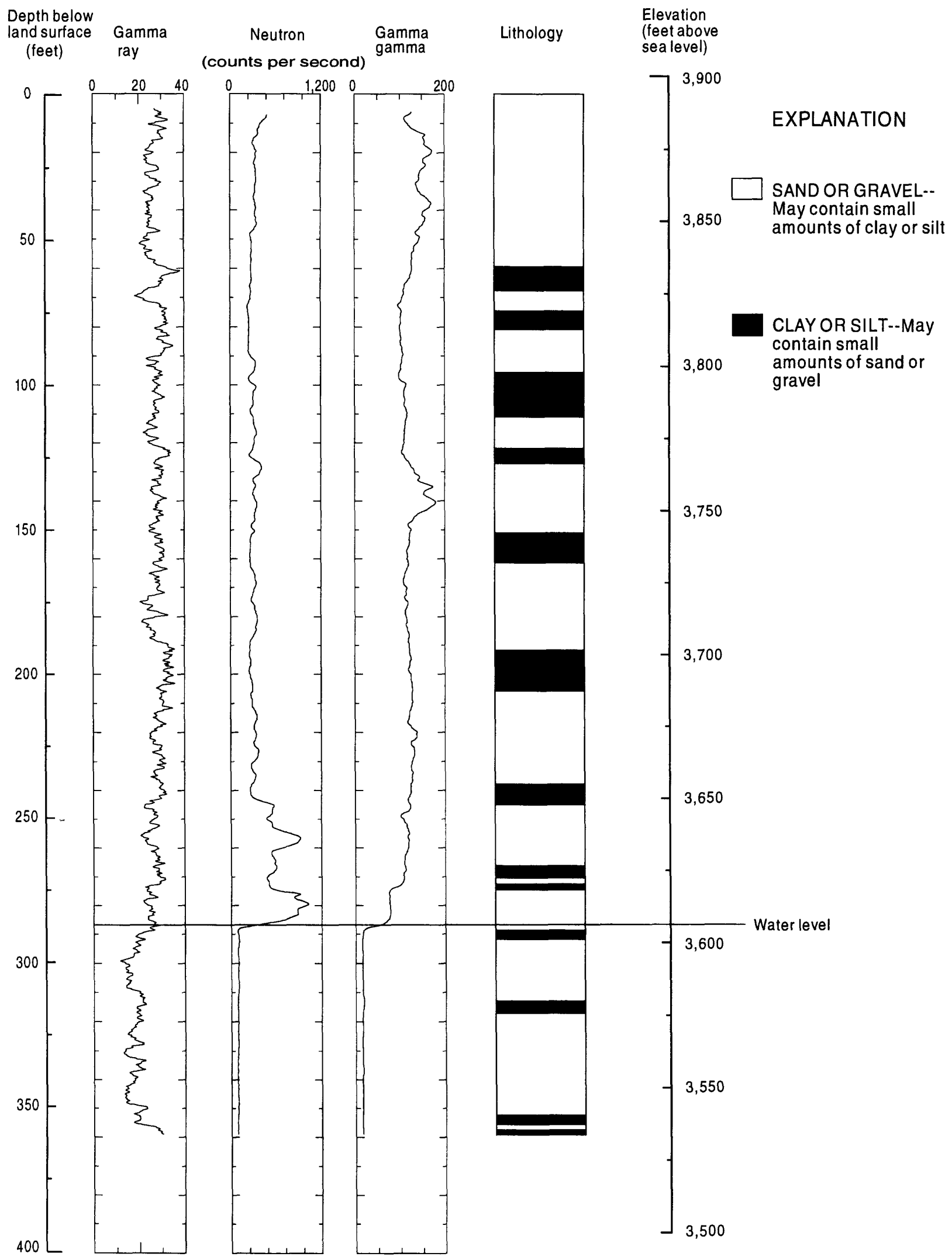

Figure 11.--Geophysical logs and interpreted lithologies at Chromic Acid Pit monitoring well MW3. 


\section{Hydrology}

An evaluation of the hydrology in the area of the Chromic Acid Pit site is dependent on an understanding of the ground-water flow system, ground-water quality, and distribution of recharge from precipitation. The following sections present information on the occurrence and quality of water resources at the Chromic Acid Pit site and vicinity. Tabulated data were compiled from U.S. Geological Survey and El Paso Water Utilities data bases.

\section{Surface Water}

The Rio Grande is the only perennial stream in the El Paso area. Flow in the Rio Grande at El Paso is regulated by upstream reservoirs and diversions and averaged 543 cubic feet per second from 1938 to 1988 (International Boundary and Water Commission, 1988, p. 9). Runoff from the western and southern slopes of the Franklin Mountains drains into the Rio Grande. Runoff from the eastern slopes of the Franklin Mountains (fig. 7) drains into the Hueco Bolson where it infiltrates and/or evaporates.

No perennial or ephemeral streams are on or in the vicinity of the Chromic Acid Pit site. Moderately defined arroyos extend from the Franklin Mountains and drain into the Hueco Bolson 2 or more miles west of the Chromic Acid Pit site. The arroyos flow only in response to intense precipitation during thunderstorms. Surface outflow from the Chromic Acid Pit site is assumed to be negligible due to the absence of surface-water flow in the vicinity of the facility.

\section{Ground Water}

The three primary sources of ground water in the El Paso area are Hueco Bolson deposits, Mesilla Bolson deposits, and Rio Grande alluvium. The primary source of ground water in the Chromic Acid Pit area is the unconsolidated and semiconsolidated sedimentary deposits of the Hueco Bolson. Wells completed in the Hueco Bolson supply water for the City of El Paso, Ciudad Juarez, Fort Bliss military reservation, private industries, and agricultural areas. Wells discharging large amounts of water usually are drilled at least 200 feet into water-yielding material. Municipal wells of the City of El Paso and Fort Bliss completed in the Hueco Bolson range in depth from about 600 feet to greater than 1,200 feet.

A relatively thick unsaturated zone of approximately 280 feet overlies the aquifer of the Hueco Bolson deposits in the vicinity of the Chromic Acid Pit site. A deep water table prevails for all of the study area. Extensive ground-water development by the City of El Paso and Fort Bliss encompasses the Chromic Acid Pit site (fig. 12; table 8).

Hydraulic characteristics of the Hueco Bolson vary significantly because of the nonuniform nature of the individual beds (Alvarez and Buckner, 1980). On a regional scale the Hueco Bolson can be considered a single aquifer, but on a local scale the rate and volume of water flowing through individual beds probably vary considerably. Transmissivities of Hueco Bolson deposits under water-table conditions in the El Paso area are estimated to be 1,340 to 37,520 feet squared per day (10,000 to 280,000 gallons per day per foot; Alvarez and Buckner, 1980, p. 6).

The Hueco Bolson aquifer underlying the chromic acid pit is recharged primarily by inflow from the mountainous areas to the north and west. Recharge resulting from direct infiltration of precipitation may be minor due to the high evaporation and low precipitation rates discussed earlier in this report. The regional direction of ground-water flow in the Hueco Bolson deposits is generally south and southwest, toward the Rio Grande. Ground-water flow direction at a given location may change from time to time due to pumpage of City of El Paso and U.S. Army production wells. The direction of flow in various strata of the aquifer at a given location is somewhat difficult to determine by the three-dimensional nature of the aquifer. Hydraulic gradients have been altered locally by extensive pumping of ground water in the El Paso area. 


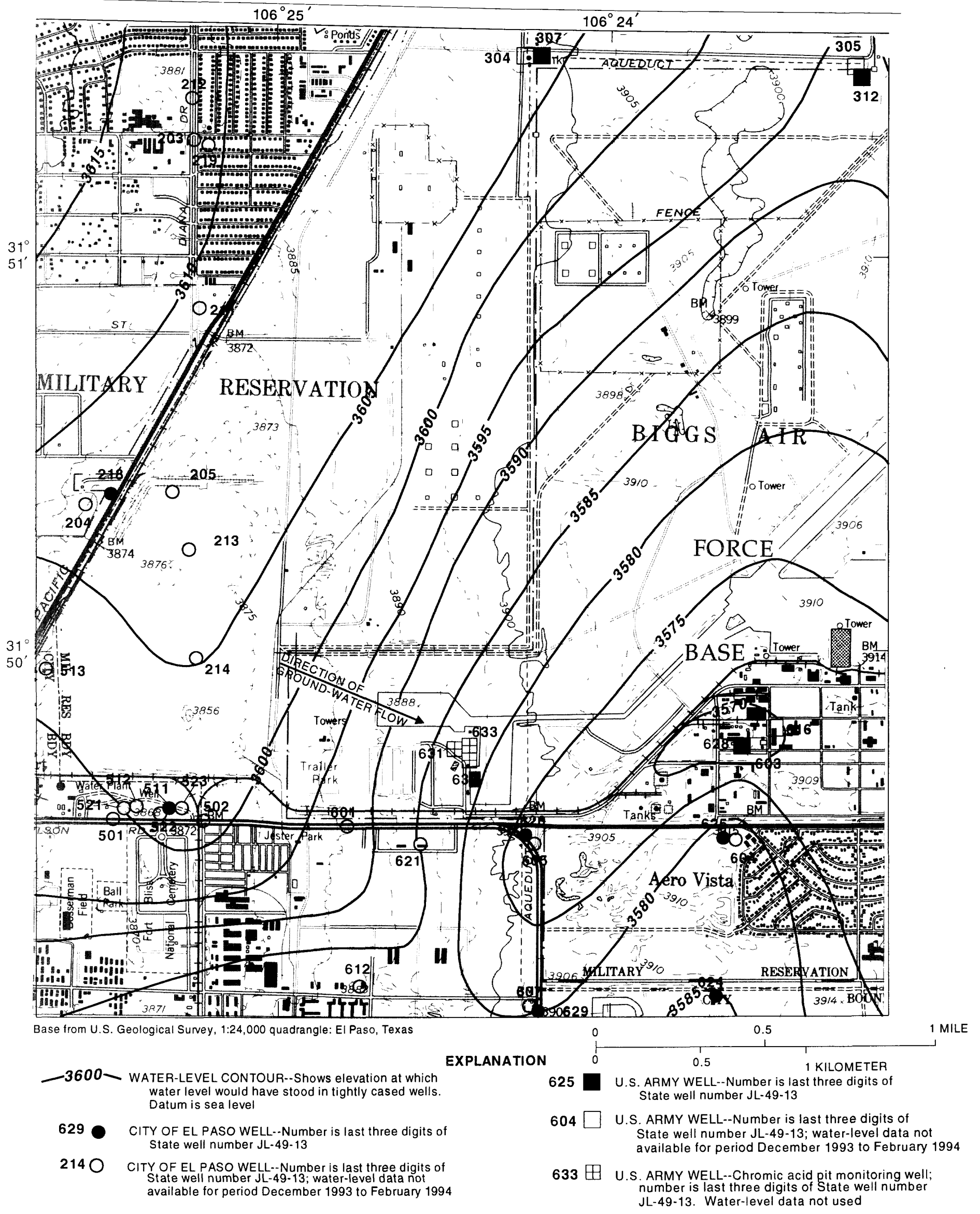

Figure 12.--Elevation of the potentiometric surface and direction of ground-water flow in the vicinity of the Chromic Acid Pit site, El Paso, Texas, January 1994 (modified from water-level map, EI Paso Water Utilities, written commun., 1994). 


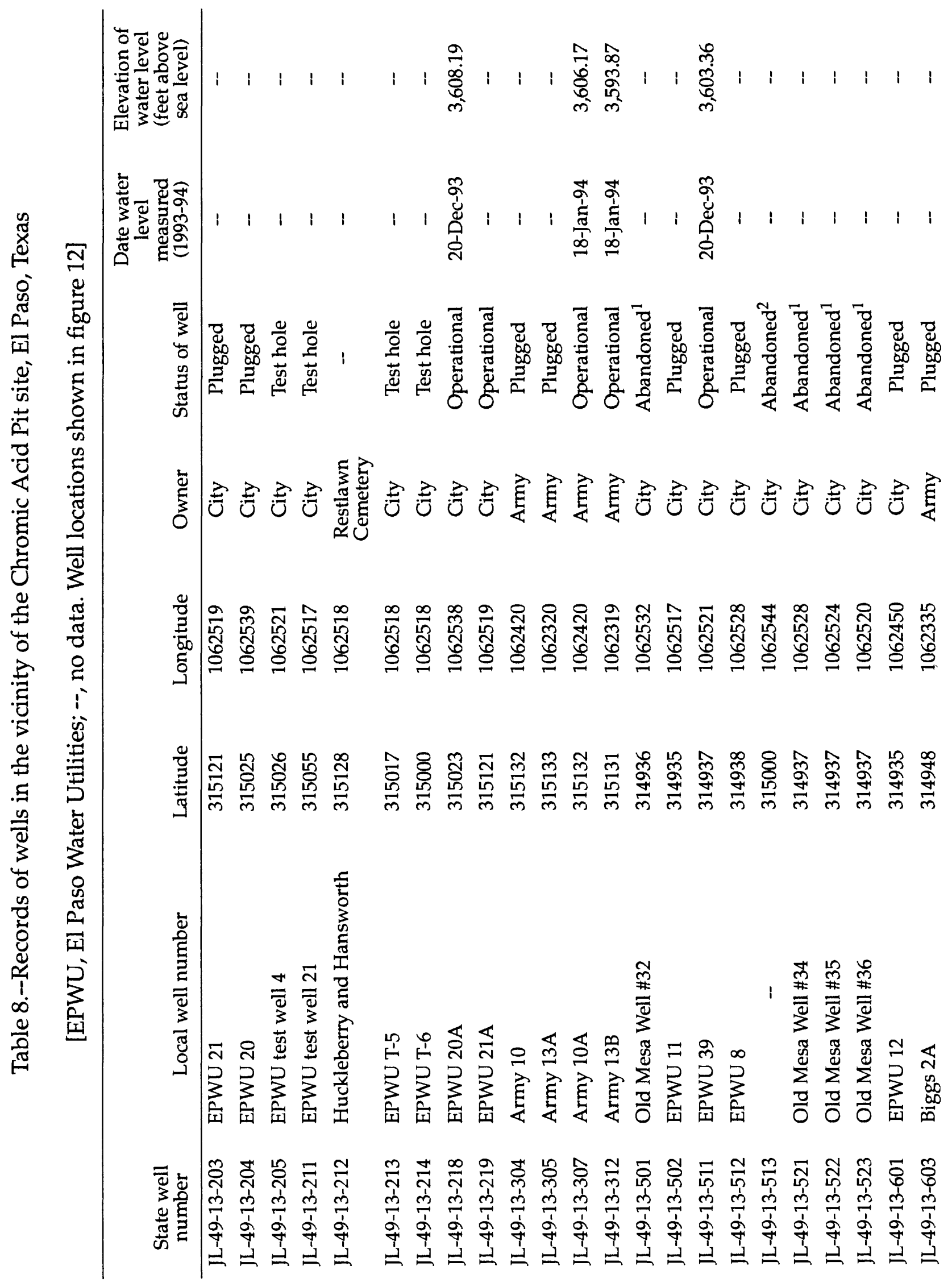




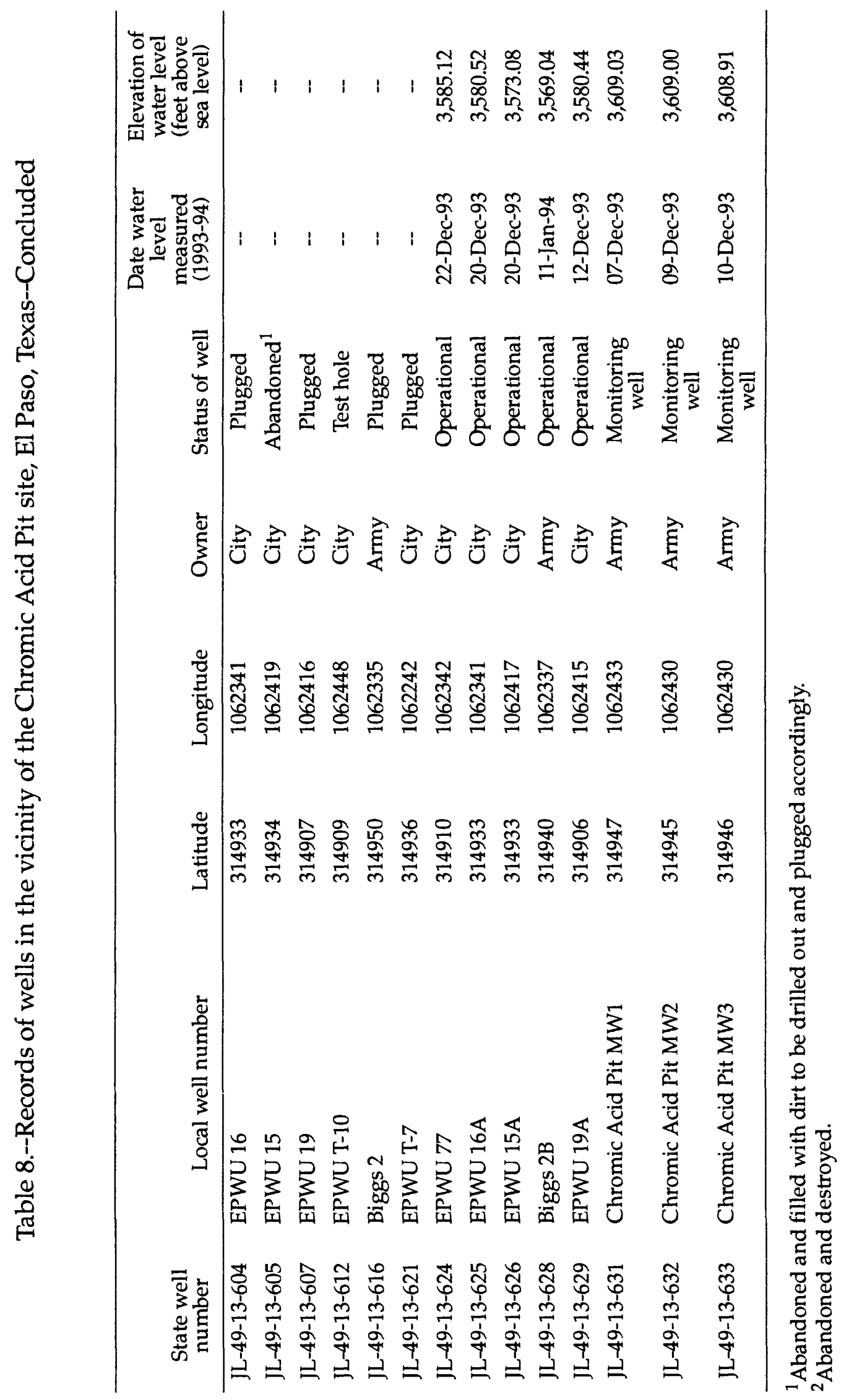


Water levels have been declining in the El Paso area. Ground-water monitoring data in the vicinity of the chromic acid pit show a water-level decline of 24.36 feet from December 1982 to December 1993 (well JL-49-13-626, fig. 12). Water pumped from wells in the vicinity of the chromic acid pit is mostly for municipal use.

Depth to water at the Chromic Acid Pit site is 283 to 285 feet below land surface (chromic acid pit monitoring wells MW1, MW2, and MW3, September 1994) (table 9). The production well currently in operation nearest the study area is E1 Paso Water Utilities (EPWU) well JL-49-13-626 located approximately 1,700 feet southeast of the Chromic Acid Pit site (fig. 12). This well is completed well below the water table and when in use pumps at a rate of 1,350-1,575 gallons per minute (El Paso Water Utilities, written commun., 1993). Depth to water at EPWU production well JL-49-13-626 is 326.9 feet below land surface (December 1993). Water-level altitudes in the chromic acid pit ground-water monitoring wells are higher by about 26 feet than water-level altitudes measured in production wells (figs. 12-16). This head difference is due to the difference in well completion; the chromic acid pit ground-water monitoring wells are completed at or near the water table and the production wells are completed more than $\mathbf{2 0 0}$ feet below the water table.

The direction of ground-water flow at the Chromic Acid Pit site is to the southeast (figs. 1216). Although water-level data at chromic acid pit monitoring wells indicate a relatively flat local hydraulic gradient (figs. 13-16), the direction of ground-water flow was assumed to follow the regional gradient. The chromic acid pit wells were completed as RCRA monitoring wells where the screen should straddle the water table. The screen in Chromic Acid Pit monitoring well MW3 straddles the water table; the water levels in MW1 and MW2 are above the screen by approximately 36 and 24 feet, respectively (using September 1994 water-level data; table 9 and figs. 3-5). The difference in pressure head in each well, due to well completion at different depths and the close proximity of the wells to each other, could account for the small variations in water levels, which are usually only tenths to hundreths of a foot among the three wells (table 9) and portray a relatively flat hydraulic gradient.

Table 9.--Water-level data for Chromic Acid Pit monitoring wells MW1, MW2, and MW3

\begin{tabular}{|c|c|c|c|c|c|c|}
\hline $\begin{array}{c}\text { Well } \\
\text { number }\end{array}$ & $\begin{array}{l}\text { Altitude of } \\
\text { top of } \\
\text { fiberglass } \\
\text { casing } \\
\text { (feet above } \\
\text { sea level) }\end{array}$ & $\begin{array}{l}\text { Altitude of } \\
\text { ground } \\
\text { surface } \\
\text { (feet above } \\
\text { sea level) }\end{array}$ & $\begin{array}{c}\text { Date } \\
\text { measured }\end{array}$ & $\begin{array}{l}\text { Depth to } \\
\text { water (feet } \\
\text { below top of } \\
\text { fiberglass } \\
\text { casing) }\end{array}$ & $\begin{array}{c}\text { Depth to } \\
\text { water (feet } \\
\text { below } \\
\text { land surface) }\end{array}$ & $\begin{array}{c}\text { Water-level } \\
\text { altitude } \\
\text { (feet above } \\
\text { sea level) }\end{array}$ \\
\hline \multirow[t]{4}{*}{ MW1 } & $3,893.95$ & $3,892.2$ & 07-Dec-93 & 284.92 & 283.1 & $3,609.03$ \\
\hline & & & 08-Mar-94 & 284.30 & 282.5 & $3,609.65$ \\
\hline & & & 07-June-94 & 284.10 & 282.3 & $3,609.85$ \\
\hline & & & 13-Sept-94 & 284.97 & 283.2 & $3,608.98$ \\
\hline \multirow[t]{4}{*}{ MW2 } & $3,895.90$ & $3,894.3$ & 09-Dec-93 & 286.90 & 285.3 & $3,609.00$ \\
\hline & & & 09-Mar-94 & 286.39 & 284.8 & $3,609.51$ \\
\hline & & & 08-June-94 & 286.17 & 284.6 & $3,609.73$ \\
\hline & & & 14-Sept-94 & 287.03 & 285.4 & $3,608.87$ \\
\hline \multirow[t]{4}{*}{ MW3 } & $3,895.78$ & $3,894.2$ & 10-Dec-93 & 286.87 & 285.3 & $3,608.91$ \\
\hline & & & 10-Mar-94 & 286.50 & 284.9 & $3,609.28$ \\
\hline & & & 09-June-94 & 286.22 & 284.6 & $3,609.56$ \\
\hline & & & 15-Sept-94 & 286.88 & 285.3 & $3,608.90$ \\
\hline
\end{tabular}




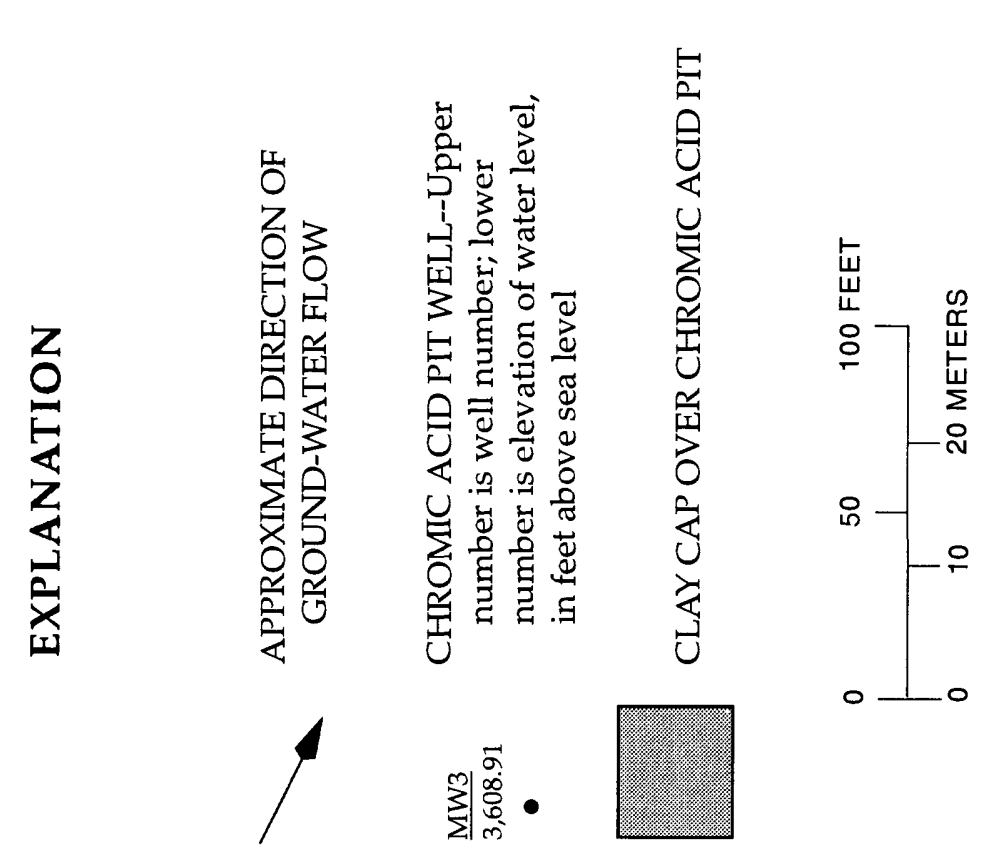

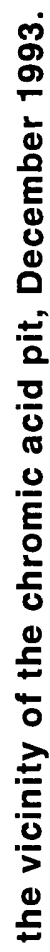

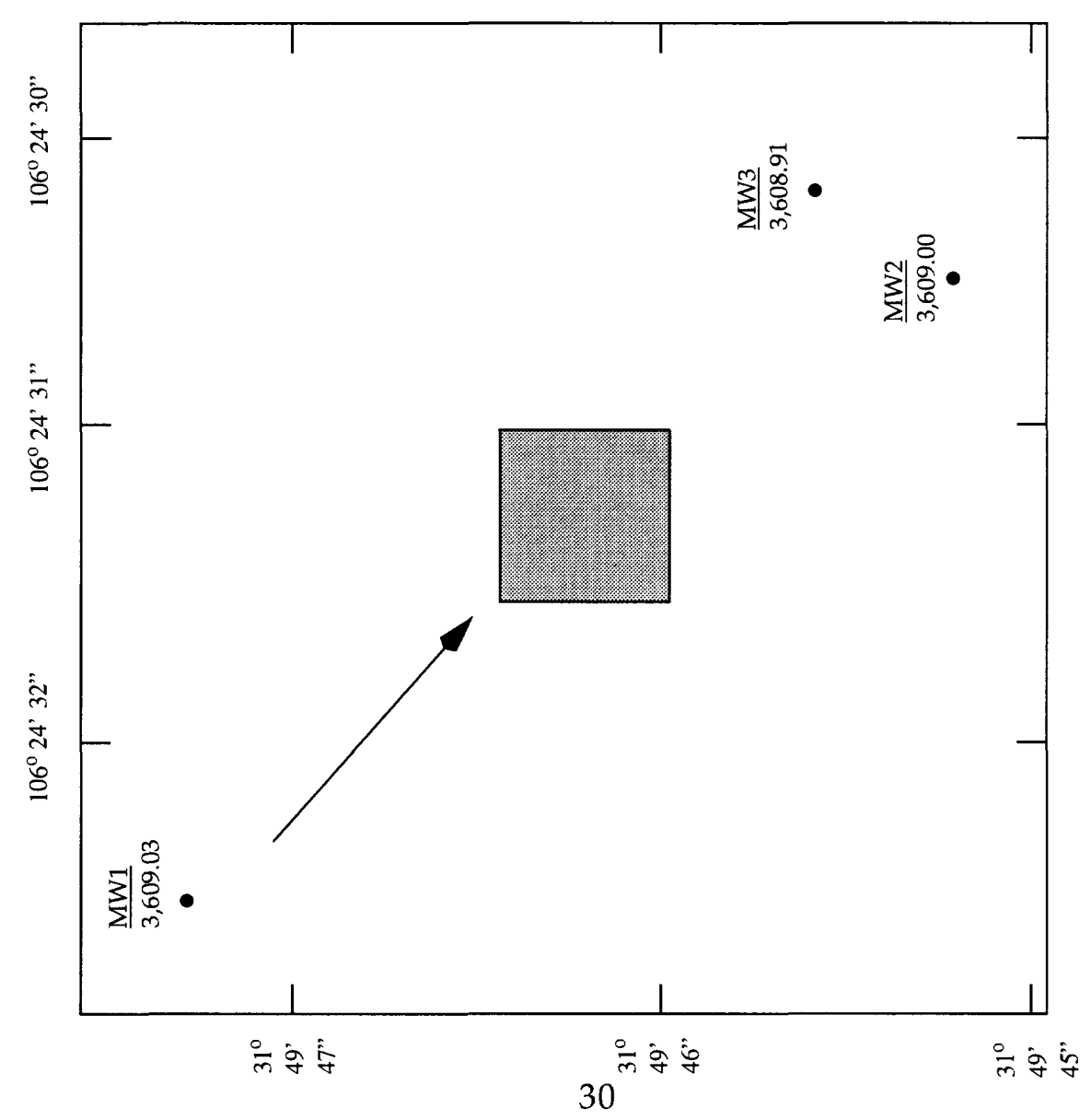




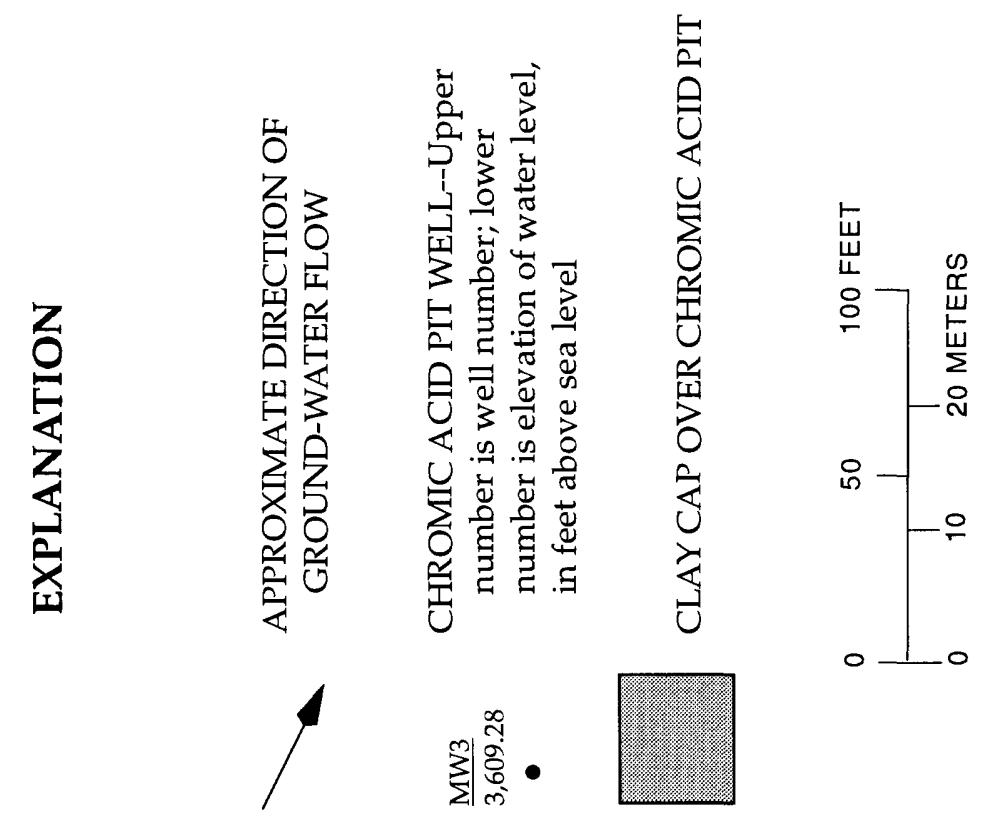

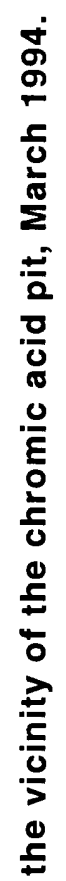

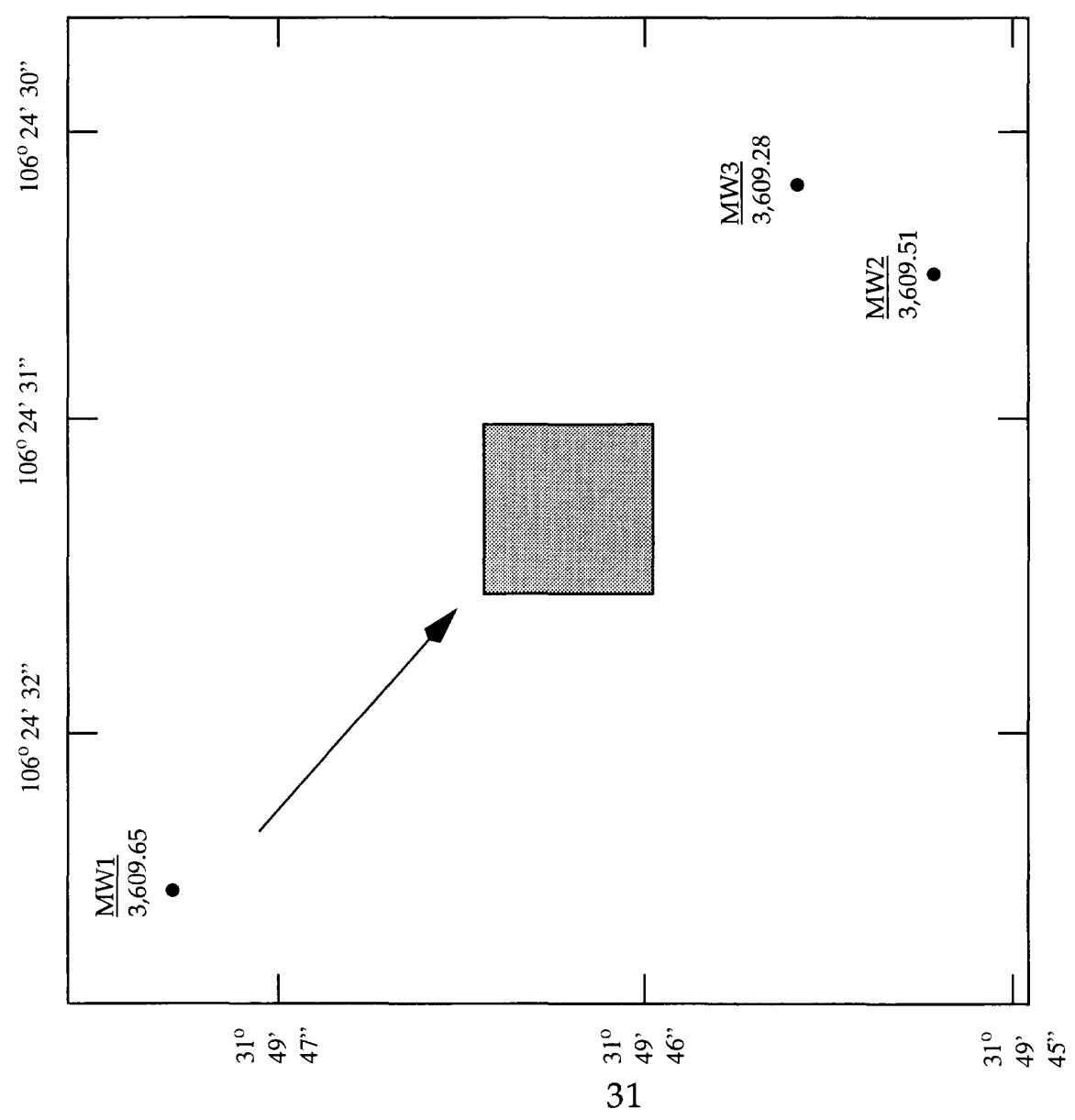




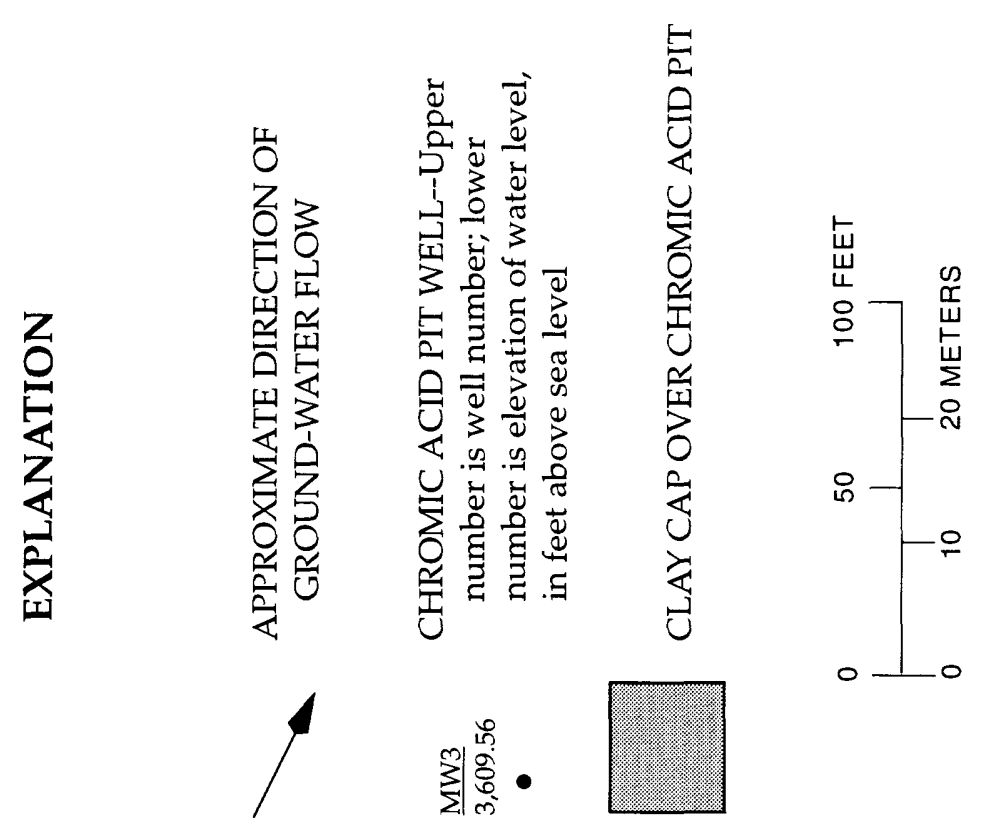

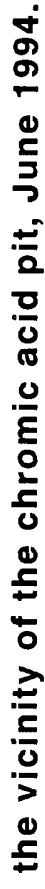

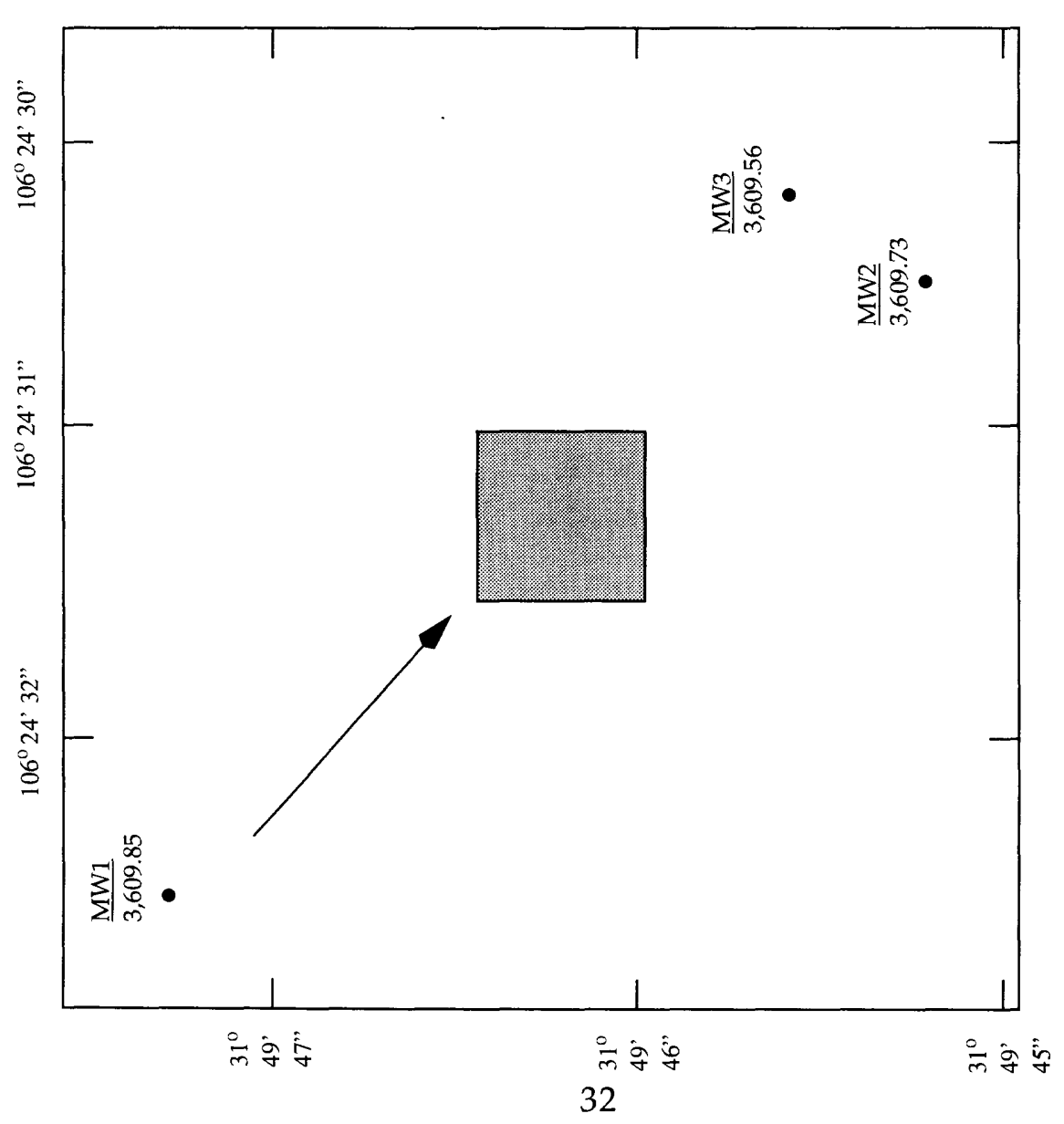




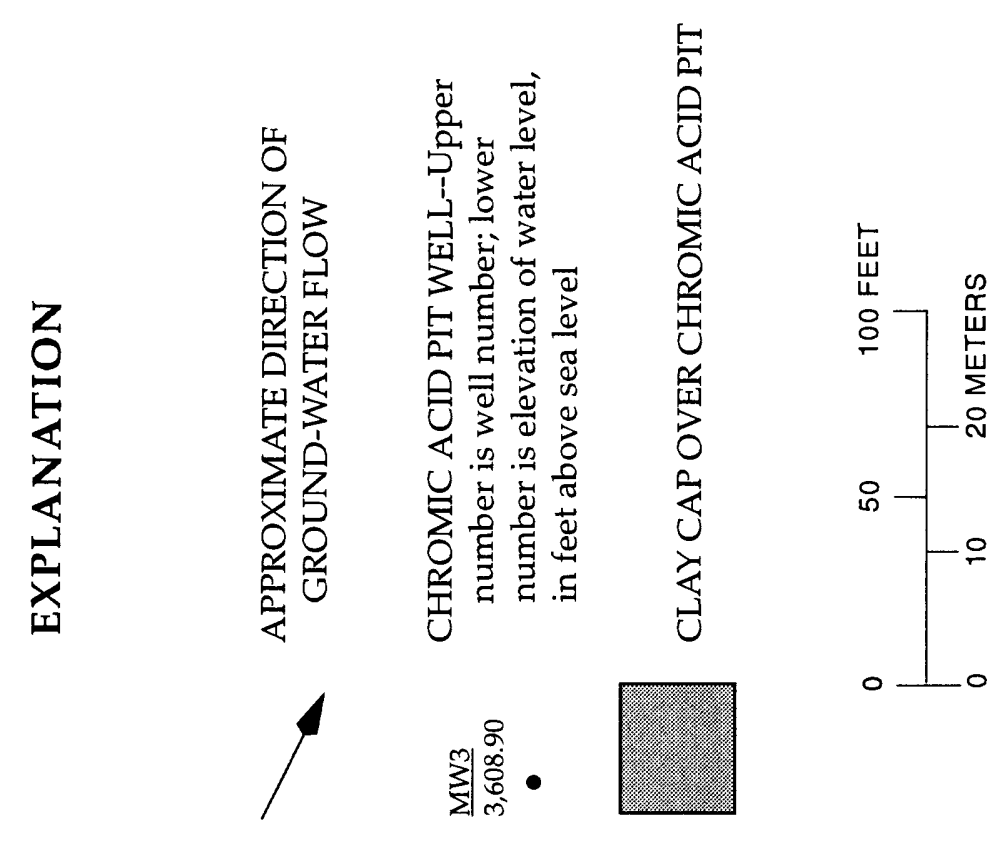

要

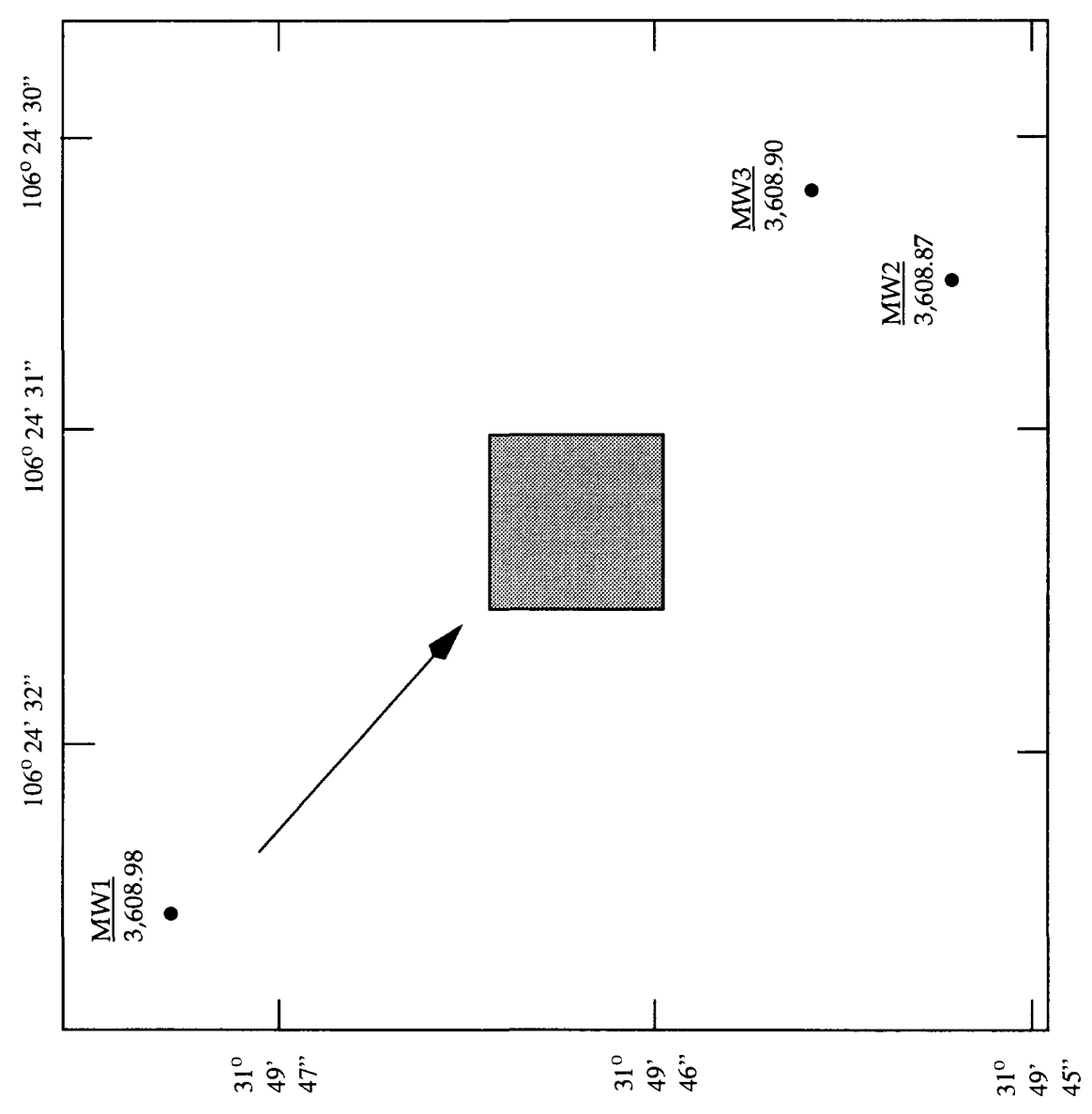




\section{GROUND-WATER QUALITY}

Available water-quality data for the Chromic Acid Pit site and vicinity include existing historical data and new data collected during the first year of quarterly ground-water monitoring at the Chromic Acid Pit site. These data provide information needed to define the quality of ground water in the upper aquifer adjacent to the Chromic Acid Pit site.

\section{Data-Collection Procedures}

Existing information on the water quality of the Hueco Bolson aquifer in the vicinity of the Chromic Acid Pit site was reviewed in reports by Cliett (1969), Alvarez and Buckner (1980), and White (1987). Water-quality data from EPWU and U.S. Geological Survey data bases were retrieved and reviewed.

New information was collected during quarterly sampling of wells MW1, MW2, and MW3 (figs. 3-5). Ground-water samples were collected in December 1993 and March, June, and September 1994 by U.S. Geological Survey personnel. Well MW1 characterizes the chemistry of ground water hydraulically upgradient from the chromic acid pit (fig. 2). This water is considered to be unaffected by potential leakage from the chromic acid pit, and well MW1 is referred to in this report as the background or upgradient well. Wells MW2 and MW3 are located hydraulically downgradient from the chromic acid pit and represent the chemistry of ground water passing below the chromic acid pit.

Ground-water sampling and analysis procedures for the Chromic Acid Pit site are discussed in detail in the TNRCC approved SAP's (U.S. Geological Survey, written commun., $1993,1994)$. The purpose of the SAP's is to ensure that data collected during the quarterly monitoring programs are of adequate quality to determine whether hazardous constituents from past disposal practices have contaminated the ground water.

Quarterly field activities included purging and sampling the designated monitoring wells. Ground-water monitoring well MW1 was purged and sampled first, followed by MW2, and finally MW3. Prior to purging each monitoring well, the water level was measured to the nearest 0.01 foot with respect to the established survey point on top of each well casing. A water sample from the surface of the water table was collected in each well using dedicated translucent Teflon bailers to examine for the presence of floating hydrocarbons. No visible immiscible layers were observed during any of the quarterly sampling events. Each well was purged prior to sampling using a dedicated PVC bailer suspended from a stainless steel cable line attached to a winch. Temperature, $\mathrm{pH}$, specific conductance, and turbidity of the purged ground water were measured routinely during purging. Wells were purged until a minimum of 3.5 well volumes of water were removed and temperature, $\mathrm{pH}$, specific conductance, and turbidity had stabilized.

Upon completion of purging, each well was immediately sampled using a dedicated Teflon bailer suspended from the cable/winch system. The appropriate sample bottles were filled from the bailer using a Teflon bottom-emptying device; the samples were immediately preserved. Duplicate-, matrix-spike, and matrix-spike-duplicate sample bottles were filled with water from the same bailer from which their respective environmental sample was collected, or from the subsequent bailer. Sample bottles for particular analytes were filled in the following order: (1) volatile organics (collected first quarter only); (2) semivolatile organics (collected first quarter only); (3) total organic halides (collected last three quarters); (4) total organic carbon (collected last three quarters); (5) metals; (6) nitrates; and (7) common ions and field properties. All equipment coming into contact with the water sample was decontaminated prior to sampling using a solution of potable water and laboratory-grade detergent and a rinse water of American Society of Testing and Materials (ASTM) Type II reagent water; the equipment was air dried on a clean, well ventilated, uncontaminated surface. 
Chain-of-custody procedures were followed to ensure that authorized personnel properly collected, protected, stored, handled, analyzed, and disposed of samples. The U.S. Geological Survey team leader who collected the sample in the field had initial custody of the samples. The analytical laboratory, Rocky Mountain Analytical Laboratory (now Quanterra Environmental Services), was the ultimate recipient of the samples. All laboratory chemical analyses were performed by Rocky Mountain Analytical Laboratory, Arvada, Colorado.

Purged water from the monitoring wells was stored in 55-gallon steel drums next to each well and classified by U.S. Geological personnel according to Title 30 TAC 335 Subchapter R. The containerized water was labeled appropriately and stored at the Chromic Acid Pit site until analytical data for that quarter's samples were received and reviewed by U.S. Geological Survey staff. After review of the quarterly analytical data, the purged water was determined to be uncontaminated. These determinations were based on comparison of analytes identified and EPA-defined maximum contamination levels (MCL's) for drinking water (U.S. Environmental Protection Agency, 1994). Once given the clearance, the purged water was properly disposed of by USAADACENFB personnel at an authorized facility. The steel drums were then reused for the next quarterly sampling event.

\section{Quality Assurance/Quality Control and Review of Analytical Data}

The objective of quality assurance/quality control (QA/QC) is to monitor the overall program for all environmentally related data collection and analyses to ensure that all data produced are suitable for evaluation and interpretation of ground-water quality at the Chromic Acid Pit site. Detailed QA objectives and goals for accuracy, precision, completeness, representativeness, and comparability and QC objectives and goals for production and documentation of quality data are defined in SAP's for the Chromic Acid Pit site (U.S. Geological Survey, written commun., December 1993, May 1994).

The field QA/QC program was developed to ensure and validate that inconsistencies in protocols did not introduce error into the data-collection process. Field QC checks were introduced into the sample collection procedures to minimize and identify (1) any inconsistencies, and (2) the potential for interference or introduction of nonenvironmental contaminants during sample collection, storage, transport, or equipment decontamination. Applicable QA/QC samples were collected and analyzed during all field sampling activities at the Chromic Acid Pit site. The following protocols were followed for collection of QA/QC field samples:

Equipment blanks were collected, one at each well, and analyzed for the same parameters as the environmental samples. These samples were collected by pouring ASTM Type II reagent water over or through the sampling equipment (winch cable, bailer, and so on) and into the appropriate sample bottle. Equipment blanks for soluble metals were run through a filtering apparatus in the field.

Field duplicates were collected, one at each well, and analyzed for the same parameters as the environmental samples. The number of field duplicates equaled the total number of environmental samples. Each field-duplicate bottle was filled immediately after filling its respective environmental sample bottle. Collection procedures for field duplicates were identical to those for the environmental samples.

Matrix-spike and matrix-spike-duplicate (MS/MSD) samples were collected, one per quarter, rotating sampling locations between monitoring wells MW1, MW2, and MW3. Each MS/MSD sample bottle (where collected) was filled immediately after filling its respective field-duplicate sample bottle. Collection 
procedures for MS/MSD samples are identical to those for the environmental samples. The filled and preserved MS/MSD sample bottles were sent to the laboratory where they were spiked with known concentrations of analytes. The MS/MSD pair was analyzed for the same parameters as its respective environmental sample.

Trip blanks were prepared using ASTM Type II reagent water shipped to the site with the sample bottles and handled as a sample. One trip blank per sampling day was prepared when water samples were collected for volatile and semivolatile organic compound analyses. When collected, trip blanks were analyzed for volatile and semivolatile organic compounds.

Ambient-conditions blanks were prepared on site using ASTM Type II reagent water. One ambient-conditions blank per sampling day was collected when water samples were collected for volatile and semivolatile organic compound analyses. A bottle of the ASTM Type II water was left open at the sampling location and then poured into its respective bottle after its respective environmental sample, sample duplicate, matrix-spike, and matrix-spike-duplicate samples were collected. When collected, ambient-conditions blanks were analyzed for volatile and semivolatile organic compounds.

The laboratory QA/QC program was evaluated relative to QA/QC sample data. The accuracy of laboratory analytical data was evaluated by the following:

Standard methods used that, whenever possible, are recognized and considered standard by the scientific community. EPA methods generally were used.

Calibration standards obtained from the National Institute of Standards and Technology EPA repository, or other reliable commercial sources.

Audit samples evaluating laboratory performance on EPA Water Supply and Water Pollution samples to maintain EPA certification.

Surrogate spikes for volatile and semivolatile organic compounds for which recovery of organic surrogate analytes should be within three standard deviations of the laboratory-established average recovery of the surrogate analyte.

Known laboratory control samples for which recovery of analytes should be within three standard deviations of the laboratory-established average recovery of the analyte. For multiple-analyte samples, 80 percent of the analytes should be within control limits. In-house control limits were used.

Recovery of analytes for which recovery should be within three standard deviations of the laboratory-established average recovery of the analyte. For multiple-analyte methods, 95 percent of the analytes should be within control limits.

Precision of analytical data was evaluated by submitting duplicate samples. These samples included duplicate-environmental samples (given a fictitious well number), matrix spikes, and matrix-spike duplicates. Analytical results for these samples should be within established control limits as defined in the SAP's for the Chromic Acid Pit site (U.S. Geological Survey, written commun., December 1993, May 1994).

Completeness was evaluated by dividing the number of valid data obtained by the total number of samples analyzed, and multiplying by 100 to give the percentage of the analytical data associated with acceptable QC criteria. If 95 percent or more of analytical data were in control, then the sample batch was determined to be in control. 
The representativeness of field data was evaluated by: (1) use of standard methods of measurement and sample collection; (2) collection of sufficient size or amount of sample; (3) documentation of reasons for use of nonstandard techniques; and (4) adherence to chain-ofcustody procedures. The representativeness of laboratory analytical data was evaluated by: (1) use of preservation techniques to minimize sample degradation that may occur between sample collection and sample analysis; (2) prescribed holding times; (3) field and laboratory blank analyses to determine whether samples have been contaminated; and (4) matrix spikes used to determine the presence of matrix effects.

Comparability of field and laboratory measurements were evaluated by standard methods of measurement and analysis and consistent reporting units, all recognized and considered as standard by the scientific community. Comparability in the laboratory was also evaluated by traceable materials for calibration and QC.

Upon completion of analyses and review of analytical and QA/QC results, the laboratory submitted quarterly laboratory analytical-results reports to the U.S. Geological Survey. The quarterly data were reviewed and a QA/QC data validation report was written by U.S. Geological Survey personnel. Data that did not meet the QA/QC objectives were identified in the $Q A / Q C$ data-validation report. Quarterly laboratory analytical-results reports and $Q A / Q C$ data-validation reports were submitted by the U.S. Geological Survey to the USAADACENFB. The USAADACENFB reviewed the data reports and submitted them to the TNRCC. Laboratory analytical-results reports and QA/QC data-validation reports are available to the public at the USAADACENFB, Directorate of Environment, El Paso, Texas, and the TNRCC Records Center, Austin, Texas.

Quarterly QA/QC laboratory analytical data collected during this first year of sampling at the Chromic Acid Pit site are not presented in this report; they may be reviewed at the locations mentioned above. Environmental-sample data from chromic acid pit ground-water monitoring wells are presented in the following section of this report. Environmental-sample data for those wells that did not meet the QA/QC objectives are still reported in the data tables but are qualified. Qualified data are flagged data that may have been non-compliant but were usable.

\section{$\underline{\text { Results of Analyses }}$}

Ground water in the El Paso area is chemically suitable for most uses. Concentrations of dissolved solids in water from Hueco Bolson fluvial deposits (fig. 17) range from 300 to more than $1,500 \mathrm{ppm}$. Concentrations of dissolved solids in water from underlying lake sediments are as much as 50,000 ppm (Cliett, 1969, p. 210).

Reported dissolved-solids concentrations in the vicinity of the Chromic Acid Pit site ranged from 320 to 522 milligrams per liter $(\mathrm{mg} / \mathrm{L})$ (table 10). Concentrations of dissolved chromium ranged from 5.9 to 10 micrograms per liter $(\mu \mathrm{g} / \mathrm{L})$ where reported above the reporting limits. Data indicate nitrate concentrates ranging from 1.2 to $12 \mathrm{mg} / \mathrm{L}$. According to White (1987) nitrogen concentrations in the Old Mesa well field are above background levels. The source of the high nitrogen concentrations may be seepage of impounded urban runoff water by way of destroyed and/or abandoned wells located on the well field (White, 1987). The Old Mesa well field is located 4,000-5,500 feet southwest of the Chromic Acid Pit site and includes wells JL-4913-501, JL-49-13-521, JL-49-13-522, and JL-49-13-523 (fig. 12; table 8). The Old Mesa well field was developed in 1904 and by 1917 included a total of 43 wells. The well field was abandoned due to low operating efficiency; production was shut down in 1926. Most of the wells were destroyed by construction in the area, and only nine have been located (White, 1987). A drainage sump, constructed in the early 1950's, is located on the Old Mesa well field. The sump has been used since its construction to collect runoff from northeast El Paso and Fort Bliss. Runoff originates mostly as impounded urban runoff (White, 1987). 


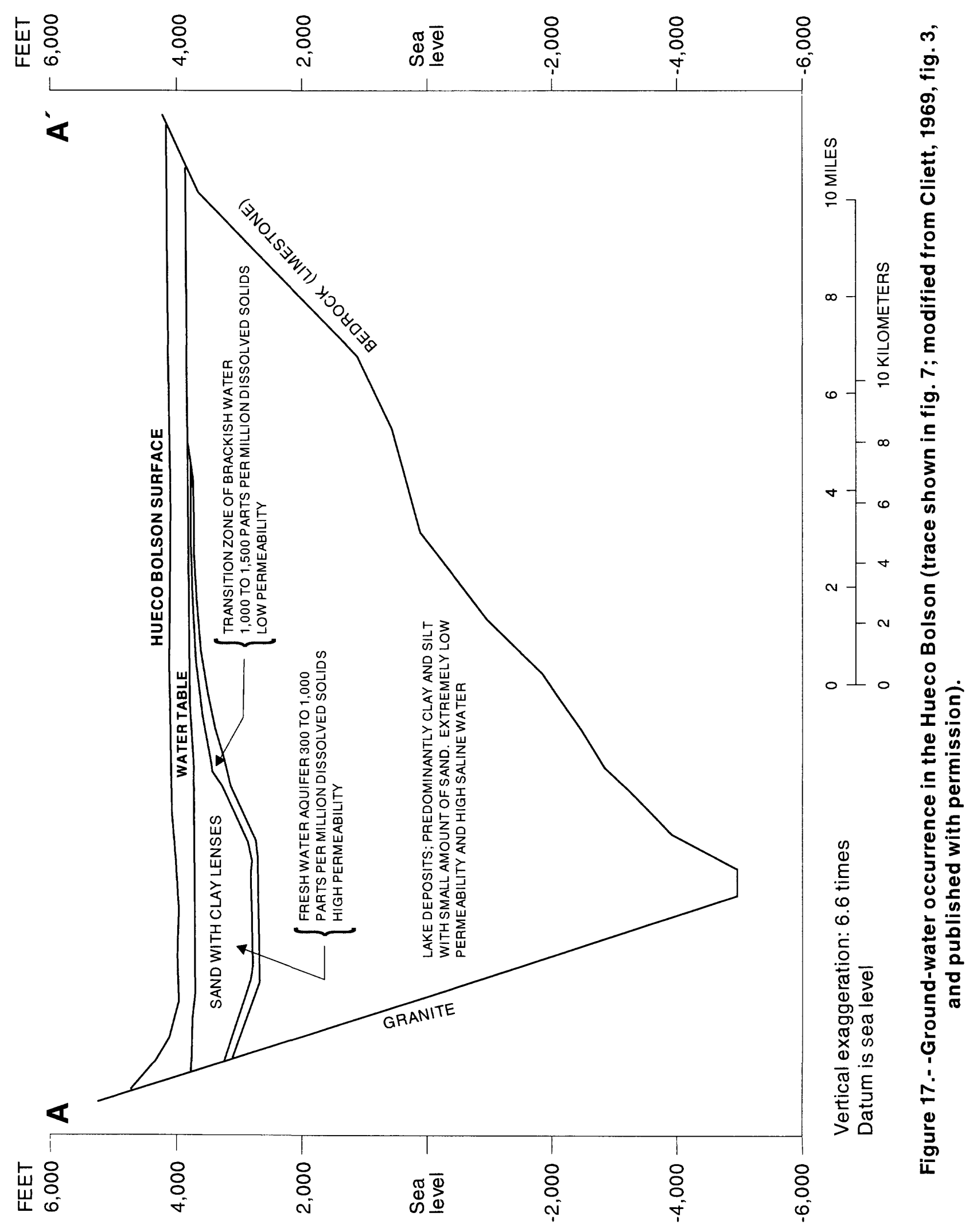



Table 10.--Chemical data for water from wells in the vicinity of the
Chromic Acid Pit site

[ $\mu \mathrm{S} / \mathrm{cm}$, microsiemens per centimeter at 25 degrees Celsius; $\mathrm{mg} / \mathrm{L}$, milligrams per liter; USGS, U.S. Geological Survey; EPWU, El Paso Water Utilities; MSL and TDH, private contractors; --, no data; <, less than; $\mu \mathrm{g} / \mathrm{L}$, micrograms per liter]

\begin{tabular}{|c|c|c|c|c|c|c|c|c|c|c|c|}
\hline $\begin{array}{l}\text { Well } \\
\text { number } \\
\text { (fig. 12) }\end{array}$ & Analyst & $\begin{array}{l}\text { Depth } \\
\text { sampled } \\
\text { (feet } \\
\text { below } \\
\text { land } \\
\text { surface) }\end{array}$ & Date & $\begin{array}{l}\text { Specific } \\
\text { con- } \\
\text { duct- } \\
\text { ance } \\
(\mu \mathrm{S} / \\
\mathrm{cm})\end{array}$ & $\mathrm{pH}$ & $\begin{array}{c}\text { Re- } \\
\text { ported } \\
\text { dis- } \\
\text { solved } \\
\text { solids } \\
(\mathrm{mg} / \mathrm{L})\end{array}$ & $\begin{array}{l}\text { Calcu- } \\
\text { lated } \\
\text { dis- } \\
\text { solved } \\
\text { solids } \\
(\mathrm{mg} / \mathrm{L})\end{array}$ & $\begin{array}{c}\text { Cal- } \\
\text { cium, } \\
\text { dis- } \\
\text { solved } \\
(\mathrm{mg} / \mathrm{L})\end{array}$ & $\begin{array}{l}\text { Magne- } \\
\text { sium, } \\
\text { dis- } \\
\text { solved } \\
(\mathrm{mg} / \mathrm{L})\end{array}$ & $\begin{array}{c}\text { So- } \\
\text { dium, } \\
\text { dis- } \\
\text { solved } \\
\text { (mg/L) }\end{array}$ & $\begin{array}{l}\text { Potas- } \\
\text { sium, } \\
\text { dis- } \\
\text { solved } \\
(\mathrm{mg} / \mathrm{L})\end{array}$ \\
\hline \multirow[t]{5}{*}{ JL-49-13-304 } & USGS & $306-756$ & $16-\mathrm{Feb}-53$ & 808 & 7.9 & 492 & 551 & 27 & 5.8 & 130 & - \\
\hline & USGS & $306-756$ & 20-July-55 & 767 & 8.2 & 480 & 528 & 26 & 18 & 125 & - \\
\hline & USGS & $306-756$ & 15-May-56 & 760 & 7.5 & 470 & 532 & 29 & 19 & 121 & - \\
\hline & USGS & $306-756$ & 24-Sept-58 & 713 & 7.8 & 449 & 515 & 24 & 18 & 121 & - \\
\hline & USGS & $306-756$ & 16-May-61 & 713 & 7.4 & 460 & 506 & 24 & 18 & 117 & - \\
\hline \multirow[t]{9}{*}{ ЛL-49-13-305 } & USGS & $270-790$ & 04-Jan-56 & 609 & 7.9 & 382 & 440 & 23 & 7.8 & 100 & - \\
\hline & USGS & $270-790$ & 15-May-56 & 619 & 7.7 & 376 & 429 & 22 & 8.0 & 97 & - \\
\hline & USGS & $270-790$ & 12-Aug-58 & 614 & 7.8 & 379 & 432 & 24 & 7.2 & 97 & - \\
\hline & USGS & $270-790$ & 24-Sept-58 & 605 & 7.8 & 368 & 428 & 22 & 7.6 & 97 & - \\
\hline & USGS & $270-790$ & 16-May-61 & 546 & 7.4 & 340 & 388 & 19 & 6.6 & 88 & - \\
\hline & USGS & $270-790$ & 05-June-81 & 550 & 8.1 & 360 & 417 & 30 & 6.3 & 77 & 10 \\
\hline & USGS & $270-790$ & 08-Aug-85 & 560 & 7.7 & 334 & 380 & 19 & 6.2 & 81 & 10 \\
\hline & USGS & $270-790$ & 18-Aug-87 & 585 & 8.20 & 330 & 393 & 19 & 6.3 & 81 & 9.9 \\
\hline & EPWU & $270-790$ & 18-Aug-87 & 540 & 8.20 & 387 & 387 & 21 & 5.7 & 79 & 10 \\
\hline \multirow[t]{5}{*}{ 几L-49-13-307 } & MSL & $330-800$ & $02-$ Oct-67 & 740 & 7.49 & 450 & 512 & 27 & 5 & 119 & - \\
\hline & USGS & $330-800$ & 22-June-81 & 690 & 8.0 & 464 & 531 & 24 & 8.1 & 120 & 11 \\
\hline & USGS & $330-800$ & 01-Sept-84 & 745 & 7.8 & 463 & 528 & 26 & 8.5 & 120 & 9.6 \\
\hline & USGS & $330-800$ & 22-May-85 & 748 & 8.0 & 445 & 506 & 25 & 8.3 & 110 & 8.1 \\
\hline & USGS & $330-800$ & 18-Aug-87 & 775 & 8.30 & 430 & 510 & 24 & 8.3 & 110 & 9.3 \\
\hline \multirow[t]{7}{*}{ JL-49-13-307 } & EPWU & $330-800$ & 18-Aug-87 & 740 & 7.82 & 522 & 522 & 28 & 7.3 & 114 & 9.6 \\
\hline & USGS & $330-800$ & 19-Sept-88 & 760 & 8.20 & 443 & 521 & 26 & 8.9 & 110 & 10 \\
\hline & USGS & $330-800$ & 19-Sept-89 & 742 & 8.00 & 450 & 527 & 25 & 8.5 & 120 & 9.4 \\
\hline & USGS & $330-800$ & 14-May-91 & 744 & 7.9 & 457 & 535 & 26 & 8.4 & 120 & 9.8 \\
\hline & USGS & $330-800$ & 16-June-93 & 755 & 7.9 & 469 & 536 & 26 & 8.5 & 120 & 10 \\
\hline & EPWU & $330-800$ & 16-June-93 & - & - & - & - & - & - & - & - \\
\hline & USGS & - & $30-\mathrm{Mar}-94$ & - & - & - & - & - & - & -- & - \\
\hline \multirow[t]{7}{*}{ JL-49-13-312 } & EPWU & $904-924$ & 24-Feb-90 & 700 & 8.68 & 370 & 456 & 29 & 5.5 & 95 & 8.6 \\
\hline & EPWU & $1,033-1,053$ & 24-Feb-90 & 955 & 8.54 & 477 & 574 & 50 & 5.3 & 123 & 8.6 \\
\hline & $\mathrm{TDH}$ & $904-924$ & $27-\mathrm{Feb}-90$ & - & - & - & - & - & - & - & -- \\
\hline & $\mathrm{TDH}$ & $1,033-1,053$ & 27-Feb-90 & - & - & - & - & - & - & - & - \\
\hline & EPWU & - & 09-June-92 & - & - & - & - & - & - & - & - \\
\hline & USGS & $480-925$ & $11-A p r-90$ & 524 & 8.10 & 322 & 381 & 18 & 5.5 & 82 & 9.8 \\
\hline & USGS & $480-925$ & 09-June-92 & 564 & 7.8 & 338 & 397 & 20 & 6.2 & 83 & 11 \\
\hline \multirow[t]{3}{*}{$\mathrm{JL}-49-13-603$} & USGS & $315-760$ & 04-Nov-64 & 584 & 7.0 & 358 & 420 & 18 & 6.3 & 99 & - \\
\hline & USGS & $315-760$ & 16-Dec-65 & 609 & 7.0 & 369 & 426 & 19 & 6.4 & 101 & - \\
\hline & USGS & $315-760$ & 05-June-81 & 530 & 8.1 & 354 & 416 & 16 & 5.9 & 93 & 10 \\
\hline \multirow[t]{3}{*}{ JL-49-13-616 } & USGS & $299-762$ & 04-Mar-52 & 665 & 8.1 & 396 & 455 & 21 & 7.1 & 107 & - \\
\hline & USGS & $299-762$ & 30-Dec-52 & 667 & 8.0 & 411 & 466 & 20 & 7.5 & 113 & - \\
\hline & USGS & 299-762 & 17-Dec-54 & 542 & 7.9 & 350 & 386 & 17 & 6.8 & 89 & - \\
\hline \multirow[t]{5}{*}{ JL-49-13-616 } & USGS & $299-762$ & 03-Nov-55 & 630 & 7.7 & 383 & 436 & 19 & 6.5 & 106 & - \\
\hline & USGS & $299-762$ & 31-Dec-56 & 652 & 7.8 & 400 & 450 & 20 & 6.3 & 110 & - \\
\hline & USGS & 299-762 & 27-Nov-57 & 663 & 7.8 & 412 & 459 & 21 & 6.7 & 112 & - \\
\hline & USGS & 299-762 & 18-Nov-59 & 633 & 7.8 & 388 & 446 & 20 & 7.2 & 106 & - \\
\hline & USGS & $299-762$ & $20-0 c t-60$ & 506 & 7.4 & 320 & 370 & 18 & 6.5 & 83 & -- \\
\hline JL-49-13-625 & USCS & - & 29-Mar-94 & - & - & - & - & - & - & - & - \\
\hline JL-49-13-626 & USGS & - & 30-Mar-94 & - & -- & - & - & - & -- & - & -- \\
\hline \multirow[t]{6}{*}{ JL-49-13-628 } & EPWU & $340-1,030$ & $15-$ Oct- 83 & - & 8.28 & 356 & 411 & 21 & 3.9 & 80 & 8.0 \\
\hline & USGS & $340-1,030$ & $01-$ Sept- 84 & 600 & 7.8 & 371 & 430 & 19 & 6.1 & 96 & 9.2 \\
\hline & USGS & $340-1,030$ & 06-May-86 & 630 & 7.9 & 390 & 464 & 18 & 6.4 & 97 & 10 \\
\hline & USGS & $340-1,030$ & 11-Sept-89 & 612 & 8.20 & 369 & 438 & 19 & 6.4 & 97 & 9.4 \\
\hline & USGS & $340-1,030$ & 29-May-91 & 618 & 8.0 & 374 & 442 & 19 & 6.5 & 99 & 9.3 \\
\hline & USGS & $340-1,030$ & 16-June-93 & 588 & 8.0 & 365 & 430 & 18 & 6.5 & 91 & 10 \\
\hline
\end{tabular}


Table 10.--Chemical data for water from wells in the vicinity of the Chromic Acid Pit site--Concluded

\begin{tabular}{|c|c|c|c|c|c|c|c|c|c|c|c|}
\hline $\begin{array}{c}\text { Well } \\
\text { number } \\
\text { (fig. 12) }\end{array}$ & Analyst & $\begin{array}{l}\text { Depth } \\
\text { sampled } \\
\text { (feet } \\
\text { below } \\
\text { land } \\
\text { surface) }\end{array}$ & Date & $\begin{array}{c}\text { Bicar- } \\
\text { bonate, } \\
\text { dis- } \\
\text { solved } \\
(\mathrm{mg} / \mathrm{L})\end{array}$ & $\begin{array}{c}\text { Car- } \\
\text { bonate, } \\
\text { dis- } \\
\text { solved } \\
(\mathrm{mg} / \mathrm{L})\end{array}$ & $\begin{array}{c}\text { Sulfate, } \\
\text { dis- } \\
\text { solved } \\
(\mathrm{mg} / \mathrm{L})\end{array}$ & $\begin{array}{l}\text { Chlo- } \\
\text { ride, } \\
\text { dis- } \\
\text { solved } \\
(\mathrm{mg} / \mathrm{L})\end{array}$ & $\begin{array}{l}\text { Fluo- } \\
\text { ride, } \\
\text { dis- } \\
\text { solved } \\
(\mathrm{mg} / \mathrm{L})\end{array}$ & $\begin{array}{l}\text { Nitrate, } \\
\text { dis- } \\
\text { solved } \\
(\mathrm{mg} / \mathrm{L})\end{array}$ & $\begin{array}{l}\text { Chro- } \\
\text { mium, } \\
\text { dis- } \\
\text { solved } \\
(\mu \mathrm{g} / \mathrm{L})\end{array}$ & $\begin{array}{l}\text { Iron, } \\
\text { dis- } \\
\text { solved } \\
(\mu g / L)\end{array}$ \\
\hline \multirow[t]{5}{*}{ JL-49-13-304 } & USGS & $306-756$ & $16-\mathrm{Feb}-53$ & 193 & 0 & 97 & 89 & 1.2 & 4.3 & $=$ & - \\
\hline & USGS & $306-756$ & 20-July-55 & 192 & 0 & 93 & 77 & 1.1 & 5.5 & - & - \\
\hline & USGS & $306-756$ & 15-May-56 & 198 & 0 & 92 & 76 & 1.5 & 5.4 & - & - \\
\hline & USGS & $306-756$ & 24-Sept-58 & 204 & 0 & 85 & 65 & 1.1 & 7.1 & - & - \\
\hline & USGS & $306-756$ & 16-May-61 & 201 & 0 & 83 & 62 & 1.3 & 9.0 & - & - \\
\hline \multirow[t]{9}{*}{ ЛL-49-13-305 } & USGS & $270-790$ & 04-Jan-56 & 173 & 0 & 70 & 60 & 1.0 & 4.8 & - & - \\
\hline & USGS & $270-790$ & 15-May-56 & 169 & 0 & 68 & 60 & 0.9 & 4.1 & - & - \\
\hline & USGS & $270-790$ & 12-Aug-58 & 172 & 0 & 66 & 60 & 0.7 & 4.8 & - & - \\
\hline & USGS & $270-790$ & 24-Sept-58 & 171 & 0 & 68 & 57 & 0.8 & 4.8 & - & - \\
\hline & USGS & $270-790$ & 16-May-61 & 166 & 0 & 55 & 45 & 1.0 & 6.9 & - & - \\
\hline & USGS & $270-790$ & 05-June-81 & 171 & 0 & 63 & 50 & 0.8 & 8.4 & - & - \\
\hline & USGS & $270-790$ & 08-Aug-85 & 152 & 0 & 54 & 49 & 1.0 & 8.0 & - & - \\
\hline & USGS & $270-790$ & 18-Aug-87 & 165 & 0 & 56 & 47 & 0.90 & 8.0 & - & - \\
\hline & EPWU & $270-790$ & 18-Aug-87 & 162 & 0 & 53 & 47 & 0.86 & 8.0 & - & - \\
\hline \multirow[t]{5}{*}{ 几L-49-13-307 } & MSL & $330-800$ & $02-O c t-67$ & 194 & 0 & 86 & 78 & - & - & - & - \\
\hline & USGS & $330-800$ & 22-June-81 & 207 & 0 & 84 & 64 & 1.2 & 12 & - & - \\
\hline & USGS & $330-800$ & $01-$ Sept-84 & 196 & 0 & 88 & 69 & 1.3 & 9.7 & - & - \\
\hline & USGS & $330-800$ & 22-May-85 & 183 & 0 & 87 & 74 & 1.3 & 9.3 & $<10$ & - \\
\hline & USGS & $330-800$ & 18-Aug-87 & 195 & - & 83 & 70 & 1.4 & 9.3 & - & - \\
\hline \multirow[t]{7}{*}{ JL-49-13-307 } & EPWU & $330-800$ & 18-Aug-87 & 199 & 0 & 83 & 70 & 1.2 & 9.8 & - & - \\
\hline & USGS & $330-800$ & $19-S e p t-88$ & 201 & 0 & 86 & 68 & 0.90 & 10 & - & - \\
\hline & USGS & $330-800$ & 19-Sept-89 & 199 & 0 & 85 & 70 & 1.3 & 8.4 & - & - \\
\hline & USGS & $330-800$ & 14-May-91 & 198 & 0 & 86 & 76 & 1.3 & 9.7 & - & -- \\
\hline & USGS & $330-800$ & 16-June-93 & 194 & 0 & 90 & 77 & 1.3 & 8.9 & - & - \\
\hline & EPWU & $330-800$ & 16-June-93 & - & - & - & - & - & - & 6.6 & $<20$ \\
\hline & USGS & - & 30-Mar-94 & - & - & - & - & - & - & 9.5 & - \\
\hline \multirow[t]{7}{*}{ JL-49-13-312 } & EPWU & $904-924$ & 24-Feb-90 & 171 & 7.3 & 67 & 66 & 0.89 & 6.1 & - & - \\
\hline & EPWU & $1,033-1,053$ & 24-Feb-90 & 190 & 7.3 & 58 & 130 & 0.76 & 1.2 & - & - \\
\hline & $\mathrm{TDH}$ & $904-924$ & $27-F e b-90$ & - & - & - & - & - & - & $<20$ & 210 \\
\hline & TDH & $1,033-1,053$ & $27-\mathrm{Feb}-90$ & - & - & - & - & - & - & $<20$ & 30 \\
\hline & EPWU & - & 09-June-92 & - & - & - & - & - & - & $<10$ & $<10$ \\
\hline & USGS & $480-925$ & 11-Apr-90 & 165 & 0 & 49 & 143 & 0.80 & 8.0 & - & - \\
\hline & USGS & $480-925$ & 09-June-92 & 162 & 0 & 57 & 49 & 0.9 & 8.0 & - & - \\
\hline \multirow[t]{3}{*}{ JL-49-13-603 } & USGS & $315-760$ & 04-Nov-64 & 184 & 0 & 62 & 46 & 1.0 & 3.2 & - & 40 \\
\hline & USGS & $315-760$ & 16-Dec-65 & 176 & 0 & 66 & 52 & 1.1 & 4.5 & - & - \\
\hline & USGS & $315-760$ & 05-June-81 & 183 & 0 & 56 & 42 & 1.0 & 8.9 & - & - \\
\hline \multirow[t]{3}{*}{ JL-49-13-616 } & USGS & $299-762$ & 04-Mar-52 & 174 & 0 & 75 & 68 & - & 2.5 & - & - \\
\hline & USGS & 299-762 & 30-Dec-52 & 174 & 0 & 78 & 69 & 1.0 & 3.0 & - & - \\
\hline & USGS & $299-762$ & 17-Dec-54 & 166 & 0 & 60 & 42 & 0.8 & 4.5 & - & - \\
\hline \multirow[t]{5}{*}{ JL-49-13-616 } & USGS & $299-762$ & 03-Nov-55 & 166 & 0 & 70 & 64 & 0.9 & 4.0 & - & -- \\
\hline & USGS & $299-762$ & 31-Dec-56 & 167 & 0 & 74 & 69 & 0.9 & 2.5 & - & - \\
\hline & USGS & $299-762$ & 27-Nov-57 & 168 & 0 & 73 & 74 & 0.8 & 3.0 & - & - \\
\hline & USGS & $299-762$ & 18-Nov-59 & 171 & 0 & 72 & 64 & 1.0 & 4.3 & - & - \\
\hline & USGS & $299-762$ & $20-0 c t-60$ & 163 & 0 & 55 & 38 & 0.9 & 5.2 & - & - \\
\hline JL-49-13-625 & USGS & - & 29-Mar-94 & - & - & - & - & - & - & 10 & - \\
\hline $\mathrm{JL}-49-13-626$ & USGS & - & 30-Mar-94 & - & - & - & - & - & - & 5.9 & - \\
\hline \multirow[t]{6}{*}{ JL-49-13-628 } & EPWU & $340-1,030$ & $15-O c t-83$ & 148 & 0 & 60 & 75 & 1.1 & 7.5 & - & - \\
\hline & USGS & $340-1,030$ & $01-$ Sept-84 & 178 & 0 & 65 & 48 & 1.1 & 8.0 & - & - \\
\hline & USGS & $340-1,030$ & 06-May-86 & 203 & 0 & 69 & 53 & 1.0 & 6.6 & - & - \\
\hline & USGS & $340-1,030$ & 11-Sept-89 & 184 & 0 & 64 & 51 & 1.0 & 6.6 & - & - \\
\hline & USGS & $340-1,030$ & 29-May-91 & 181 & 0 & 63 & 56 & 1.0 & 7.5 & - & - \\
\hline & USGS & $340-1,030$ & 16-June-93 & 187 & 0 & 65 & 43 & 1.0 & 8.9 & - & - \\
\hline
\end{tabular}


Water-quality data for the first year of quarterly ground-water monitoring at the Chromic Acid Pit site are presented in tables 11-14; associated data-qualifier codes are presented in table 15. The temperature of water samples from chromic acid pit wells ranged from 23.0 to 25.0 ${ }^{\circ} \mathrm{C}$. Turbidity ranged from 5.73 to 30.1 nephelometric turbidity units (NTU's) in water from well MW1; from 10.9 to 25.2 NTU's in water from well MW2; and from 29.4 to 122 NTU's in water from well MW3. The higher turbidity values measured in water from well MW3 during the December 1993 and March 1994 sampling events are due to the presence of drilling mud, possibly still in the formation, from installation of the well. Drilling mud and abundant sediment were observed in well MW3 during the initial sampling in December 1993 and during an initial well inspection with a downhole camera in November 1993. Drill mud was also present, in lesser amounts, in water from well MW2. Turbidity values in all three wells decreased over time.

The $\mathrm{pH}$ of the water samples from well MW1 ranged from 8.22 to 9.09; in well MW2 ranged from 7.47 to 7.98; and in well MW3 ranged from 7.79 to 8.13 . Water in well MW1 was more basic than water from wells MW2 and MW3; which may be due to well completion and development (possibly cement grout getting into the screened interval in well MW1). Over time, the $\mathrm{pH}$ in water from well MW1 is approaching $\mathrm{pH}$ values in water from wells MW2 and MW3 (tables 11-14). The pH of water samples from wells MW2 and MW3 is similar to $\mathrm{pH}$ in ground water in the vicinity of the Chromic Acid Pit site (table 10). Specific conductance of water from the chromic acid pit wells ranged from 698 to 834 microsiemens per centimeter at $25^{\circ} \mathrm{C}$.

Alkalinity of water samples was measured in the field immediately after sampling. The dissolved carbonate concentration in water samples, calculated from field alkalinity and $\mathrm{pH}$, ranged from zero to $41 \mathrm{mg}$ / $\mathrm{L}$ in well MW1; calculated carbonate concentration was zero in water from wells MW2 and MW3. Calculated bicarbonate concentration in water samples ranged from 50 to $193 \mathrm{mg} / \mathrm{L}$ in well MW1, from 227 to $233 \mathrm{mg} / \mathrm{L}$ in well MW2, and from 234 to $244 \mathrm{mg} / \mathrm{L}$ in well MW3. Alkalinity as calcium carbonate in water samples ranged from 109 to $162 \mathrm{mg} / \mathrm{L}$ in well MW1, from 186 to $191 \mathrm{mg} / \mathrm{L}$ in well MW2, and from 192 to $200 \mathrm{mg} / \mathrm{L}$ in well MW3.

Analyses for common ions included total chloride, fluoride, nitrate, orthophosphate, and sulfate for all four quarters, and total and dissolved calcium, magnesium, potassium, and sodium for the March, June, and September sampling events (tables 11-14). Ground water at the Chromic Acid Pit site generally contains relatively large amounts of sodium and bicarbonate. Nitrate as nitrogen concentrations in water samples ranged from 2.1 to $2.7 \mathrm{mg} / \mathrm{L}$; concentrations of nitrite plus nitrate as nitrogen ranged from 2.3 to $3.0 \mathrm{mg} / \mathrm{L}$. Dissolved-solids concentrations in the three monitoring wells ranged from 442 to $564 \mathrm{mg} / \mathrm{L}$. Suspended-solids concentrations ranged from 5.2 to $47.2 \mathrm{mg} / \mathrm{L}$ in water samples from wells MW1 and MW2, and from 24 to 219 $\mathrm{mg} / \mathrm{L}$ in water samples from well MW3. Results for some common ions, dissolved solids, and suspended solids had associated qualifiers (tables 11-14). 
Table 11.--Analytical results of quarterly ground-water monitoring at the Chromic Acid Pit site, U.S. Army Air Defense Artillery Center and Fort Bliss, El Paso, Texas, first quarter, December 1993

[Qualifier codes are identified in table 15. --, no data; NTU's, nephelometric turbidity units; $\mu \mathrm{S} / \mathrm{cm}$, microsiemens per centimeter at 25 degrees Celsius; $\mathrm{mg} / \mathrm{L}$, milligrams per liter, $\mu \mathrm{g} / \mathrm{L}$, micrograms per liter; ND, not detected]

\begin{tabular}{|c|c|c|c|c|c|}
\hline Parameter and unit & Method & $\begin{array}{l}\text { Laboratory } \\
\text { reporting } \\
\text { limit }\end{array}$ & $\begin{array}{c}\text { Well MW1 } \\
\text { result/qualifier }\end{array}$ & $\begin{array}{c}\text { Well MW2 } \\
\text { result/qualifier }\end{array}$ & $\begin{array}{l}\text { Well MW3 } \\
\text { result/qualifier }\end{array}$ \\
\hline Date & -. & -- & 07-Dec-93 & 09-Dec-93 & 10-Dec-93 \\
\hline Time & - & - & 1500 & 1530 & 1540 \\
\hline U.S. Geological Survey sample number & - & -- & CAP1001 & CAP2001 & САР3001 \\
\hline Laboratory sample number & -- & -- & $032678-0001-S A$ & $032678-0006-S A$ & 032678-0011-SA \\
\hline $\begin{array}{l}\text { Water level, elevation, feet above sea } \\
\text { level, prior to pumping }\end{array}$ & -- & 0.01 & $3,609.03$ & $3,609.00$ & $3,608.91$ \\
\hline $\begin{array}{l}\text { Amount purged prior to sampling, } \\
\text { gallons }\end{array}$ & -- & 1 & 220 & 189 & 190.5 \\
\hline $\begin{array}{l}\text { Depth sampled, feet below land } \\
\text { surface }\end{array}$ & - & 1 & 330 & 330 & 310 \\
\hline \multicolumn{6}{|l|}{ Field properties: } \\
\hline Temperature, degrees Celsius & E170.1 & 0.1 & 24.0 & 23.5 & 23.5 \\
\hline Turbidity, NTU's & E180.1 & 1 & 15.8 & 17.9 & 55.2 \\
\hline $\mathrm{pH}$ & E150.1 & 0.1 & 9.05 & 7.47 & 8.13 \\
\hline Specific conductance, $\mu \mathrm{S} / \mathrm{cm}$ & E120.1 & 10.0 & 698 & 766 & 797 \\
\hline Alkalinity, carbonate, mg/L & A403 & -- & 41 & 0 & 0 \\
\hline Alkalinity, bicarbonate, mg/L & A403 & 10 & 50 & 227 & 234 \\
\hline Alkalinity, calcium carbonate, mg/L & A403 & 10 & 109 & 186 & 192 \\
\hline Dissolved solids, mg/L & E160.1 & 10.0 & 442 & 492 & 522 \\
\hline Suspended solids, mg/L & E160.2 & 2.0 & $26.0 / D$ & $18.4 / \mathrm{D}$ & 86.4 \\
\hline \multicolumn{6}{|l|}{ Common anions: } \\
\hline Chloride, total, $\mathrm{mg} / \mathrm{L}$ & E300 & 0.50 & 80.8 & 65.3 & 68.8 \\
\hline Fluoride, total, mg/L & E300 & 0.50 & 1.5 & 1.4 & 1.4 \\
\hline Nitrate as nitrogen, total, $\mathrm{mg} / \mathrm{L}$ & E300 & 0.50 & 2.1 & 2.6 & 2.3 \\
\hline $\begin{array}{l}\text { Nitrite plus nitrate as nitrogen, total, } \\
\mathrm{mg} / \mathrm{L}\end{array}$ & E353.2 & 0.10 & 2.4 & 2.9 & 2.7 \\
\hline $\begin{array}{l}\text { Orthophosphate as phosphorus, total, } \\
\mathrm{mg} / \mathrm{L}\end{array}$ & E300 & 0.50 & ND & ND & ND \\
\hline Sulfate, total, $\mathrm{mg} / \mathrm{L}$ & E300 & 0.50 & 104 & 101 & 105 \\
\hline \multicolumn{6}{|l|}{ Volatile organic compounds: } \\
\hline Acetone, $\mu \mathrm{g} / \mathrm{L}$ & SW8240 & 10 & ND & ND & ND \\
\hline Acetonitrile, $\mu \mathrm{g} / \mathrm{L}$ & SW8240 & 200 & ND & ND & ND \\
\hline Acrolein, $\mu \mathrm{g} / \mathrm{L}$ & SW8240 & 100 & ND & ND & ND \\
\hline Acrylonitrile, $\mu \mathrm{g} / \mathrm{L}$ & SW8240 & 100 & ND & ND & ND \\
\hline Allyl chloride, $\mu \mathrm{g} / \mathrm{L}$ & SW8240 & 10 & ND & ND & ND \\
\hline Benzene, $\mu \mathrm{g} / \mathrm{L}$ & SW8240 & 5.0 & ND & ND & ND \\
\hline
\end{tabular}


Table 11.--Analytical results of quarterly ground-water monitoring at the Chromic Acid Pit site, U.S. Army Air Defense Artillery Center and Fort Bliss, El Paso, Texas, first quarter, December 1993-Continued

\begin{tabular}{|c|c|c|c|c|c|}
\hline Parameter and unit & Method & $\begin{array}{l}\text { Laboratory } \\
\text { reporting } \\
\text { limit }\end{array}$ & $\begin{array}{l}\text { Well MW1 } \\
\text { result/qualifier }\end{array}$ & $\begin{array}{l}\text { Well MW2 } \\
\text { result/qualifier }\end{array}$ & $\begin{array}{l}\text { Well MW3 } \\
\text { result/qualifier }\end{array}$ \\
\hline \multicolumn{6}{|l|}{ Volatile organic compounds--Continued: } \\
\hline Bromomethane, $\mu \mathrm{g} / \mathrm{L}$ & SW8240 & 10 & ND & ND & ND \\
\hline Carbon disulfide, $\mu \mathrm{g} / \mathrm{L}$ & SW8240 & 5.0 & ND & ND & ND \\
\hline Carbon tetrachloride, $\mu \mathrm{g} / \mathrm{L}$ & SW8240 & 5.0 & ND & ND & ND \\
\hline Chlorobenzene, $\mu \mathrm{g} / \mathrm{L}$ & SW8240 & 5.0 & ND & ND & ND \\
\hline Chloroethane, $\mu \mathrm{g} / \mathrm{L}$ & SW8240 & 10 & ND & ND & ND \\
\hline Chloroform, $\mu \mathrm{g} / \mathrm{L}$ & SW8240 & 5.0 & ND & ND & ND \\
\hline Chloromethane, $\mu \mathrm{g} / \mathrm{L}$ & SW8240 & 10 & ND & ND & ND \\
\hline Chloroprene, $\mu \mathrm{g} / \mathrm{L}$ & SW8240 & 5.0 & ND & ND & ND \\
\hline Dibromochloromethane, $\mu \mathrm{g} / \mathrm{L}$ & SW8240 & 5.0 & ND & ND & ND \\
\hline Dibromomethane, $\mu \mathrm{g} / \mathrm{L}$ & SW8240 & 5.0 & ND & ND & ND \\
\hline Dichlorodifluoromethane, $\mu \mathrm{g} / \mathrm{L}$ & SW8240 & 20 & ND & ND & ND \\
\hline Ethyl methacrylate, $\mu \mathrm{g} / \mathrm{L}$ & SW8240 & 20 & ND & ND & ND \\
\hline Iodomethane, $\mu \mathrm{g} / \mathrm{L}$ & SW8240 & 5.0 & ND & ND & ND \\
\hline Isobutanol, $\mu \mathrm{g} / \mathrm{L}$ & SW8240 & 200 & ND & ND & ND \\
\hline Methacrylonitrile, $\mu \mathrm{g} / \mathrm{L}$ & SW8240 & 5.0 & ND & ND & ND \\
\hline Methyl methacrylate, $\mu \mathrm{g} / \mathrm{L}$ & SW8240 & 20 & ND & ND & ND \\
\hline Methylene chloride, $\mu \mathrm{g} / \mathrm{L}$ & SW8240 & 5.0 & ND & ND & ND \\
\hline Styrene, $\mu \mathrm{g} / \mathrm{L}$ & SW8240 & 5.0 & ND & ND & ND \\
\hline Tetrachloroethene, $\mu \mathrm{g} / \mathrm{L}$ & SW8240 & 5.0 & ND & ND & ND \\
\hline Toluene, $\mu \mathrm{g} / \mathrm{L}$ & SW8240 & 5.0 & ND & ND & ND \\
\hline Trichloroethene, $\mu \mathrm{g} / \mathrm{L}$ & SW8240 & 5.0 & ND & ND & ND \\
\hline Trichlorofluoromethane, $\mu \mathrm{g} / \mathrm{L}$ & SW8240 & 5.0 & ND & ND & ND \\
\hline Vinyl acetate, $\mu \mathrm{g} / \mathrm{L}$ & SW8240 & 10 & ND & ND & ND \\
\hline Vinyl chloride, $\mu \mathrm{g} / \mathrm{L}$ & SW8240 & 10 & ND & ND & ND \\
\hline Xylenes (total), $\mu \mathrm{g} / \mathrm{L}$ & SW8240 & 5.0 & ND & ND & ND \\
\hline cis-1,3-Dichloropropene, $\mu \mathrm{g} / \mathrm{L}$ & SW8240 & 5.0 & ND & ND & ND \\
\hline trans-1,3-Dichloropropene, $\mu \mathrm{g} / \mathrm{L}$ & SW8240 & 5.0 & ND & ND & ND \\
\hline trans-1,4-Dichloro-2-butene, $\mu \mathrm{g} / \mathrm{L}$ & SW8240 & 5.0 & ND & ND & ND \\
\hline 1,1,1,2-Tetrachloroethane, $\mu \mathrm{g} / \mathrm{L}$ & SW8240 & 5.0 & ND & ND & ND \\
\hline 1,1,1-Trichloroethane, $\mu \mathrm{g} / \mathrm{L}$ & SW8240 & 5.0 & ND & ND & ND \\
\hline 1,1,2,2-Tetrachloroethane, $\mu \mathrm{g} / \mathrm{L}$ & SW8240 & 5.0 & ND & ND & ND \\
\hline 1,1,2-Trichloroethane, $\mu \mathrm{g} / \mathrm{L}$ & SW8240 & 5.0 & ND & ND & ND \\
\hline 1,1-Dichloroethane, $\mu \mathrm{g} / \mathrm{L}$ & SW8240 & 5.0 & ND & ND & ND \\
\hline 1,1-Dichloroethene, $\mu \mathrm{g} / \mathrm{L}$ & SW8240 & 5.0 & ND & ND & ND \\
\hline 1,2,3-Trichloropropane, $\mu \mathrm{g} / \mathrm{L}$ & SW8240 & 5.0 & ND & ND & ND \\
\hline $\begin{array}{l}\text { 1,2-Dibromo-3-chloro-propane (DB), } \\
\mu \mathrm{g} / \mathrm{L}\end{array}$ & SW8240 & 10 & ND & ND & ND \\
\hline 1,2-Dibromoethane (EDB), $\mu \mathrm{g} / \mathrm{L}$ & SW8240 & 10 & ND & ND & ND \\
\hline 1,2-Dichloroethane, $\mu \mathrm{g} / \mathrm{L}$ & SW8240 & 5.0 & ND & ND & ND \\
\hline 1,2-Dichloroethene (total), $\mu \mathrm{g} / \mathrm{L}$ & SW8240 & 5.0 & ND & ND & ND \\
\hline 1,2-Dichloropropane, $\mu \mathrm{g} / \mathrm{L}$ & SW8240 & 5.0 & ND & ND & ND \\
\hline
\end{tabular}


Table 11.--Analytical results of quarterly ground-water monitoring at the Chromic Acid Pit site, U.S. Army Air Defense Artillery Center and Fort Bliss, El Paso, Texas, first quarter, December 1993--Continued

\begin{tabular}{|c|c|c|c|c|c|}
\hline Parameter and unit & Method & $\begin{array}{l}\text { Laboratory } \\
\text { reporting } \\
\text { limit }\end{array}$ & $\begin{array}{l}\text { Well MW1 } \\
\text { result/qualifier }\end{array}$ & $\begin{array}{l}\text { Well MW2 } \\
\text { result/qualifier }\end{array}$ & $\begin{array}{l}\text { Well MW3 } \\
\text { result/qualifier }\end{array}$ \\
\hline \multicolumn{6}{|l|}{ Volatile organic compounds-Continued: } \\
\hline 1,4-Dioxane, $\mu \mathrm{g} / \mathrm{L}$ & SW8240 & 500 & ND & ND & ND \\
\hline 2-Butanone (MEK), $\mu \mathrm{g} / \mathrm{L}$ & SW8240 & 10 & ND & ND & ND \\
\hline 2-Hexanone, $\mu \mathrm{g} / \mathrm{L}$ & SW8240 & 10 & ND & ND & ND \\
\hline 4-Methyl-2-pentanone (MIBK), $\mu \mathrm{g} / \mathrm{L}$ & SW8240 & 10 & ND & ND & ND \\
\hline \multicolumn{6}{|l|}{ Semivolatile organic compounds: } \\
\hline Acenaphthene, $\mu \mathrm{g} / \mathrm{L}$ & SW8270 & 10 & ND & ND & ND \\
\hline Acenaphthylene, $\mu \mathrm{g} / \mathrm{L}$ & SW8270 & 10 & ND & ND & ND \\
\hline Acetophenone, $\mu \mathrm{g} / \mathrm{L}$ & SW8270 & 10 & ND & ND & ND \\
\hline Aniline, $\mu \mathrm{g} / \mathrm{L}$ & SW8270 & 10 & ND & ND & ND \\
\hline Anthracene, $\mu \mathrm{g} / \mathrm{L}$ & SW8270 & 10 & ND & ND & ND \\
\hline Aramite, $\mu \mathrm{g} / \mathrm{L}$ & SW8270 & 10 & ND & ND & ND \\
\hline Benzo(a)anthracene, $\mu \mathrm{g} / \mathrm{L}$ & SW8270 & 10 & ND & ND & ND \\
\hline Benzo(a)pyrene, $\mu \mathrm{g} / \mathrm{L}$ & SW8270 & 10 & ND & ND & ND \\
\hline Benzo(b)fluoranthene, $\mu \mathrm{g} / \mathrm{L}$ & SW8270 & 10 & ND & ND & ND \\
\hline Benzo(g,h,i)perylene, $\mu \mathrm{g} / \mathrm{L}$ & SW8270 & 10 & ND & ND & ND \\
\hline Benzo(k)fluoranthene, $\mu \mathrm{g} / \mathrm{L}$ & SW8270 & 10 & ND & ND & ND \\
\hline Benzyl alcohol, $\mu \mathrm{g} / \mathrm{L}$ & SW8270 & 10 & ND & ND & ND \\
\hline Butyl benzyl phthalate, $\mu \mathrm{g} / \mathrm{L}$ & SW8270 & 10 & ND & ND & ND \\
\hline Chrysene, $\mu \mathrm{g} / \mathrm{L}$ & SW8270 & 10 & ND & ND & ND \\
\hline Di-n-butyl phthalate, $\mu \mathrm{g} / \mathrm{L}$ & SW8270 & 10 & ND & ND & ND \\
\hline Di-n-octyl phthalate, $\mu \mathrm{g} / \mathrm{L}$ & sw8270 & 10 & ND & ND & ND \\
\hline Dibenz(a,h)anthracene, $\mu \mathrm{g} / \mathrm{L}$ & SW8270 & 10 & ND & ND & ND \\
\hline Dibenzofuran, $\mu \mathrm{g} / \mathrm{L}$ & SW8270 & 10 & ND & ND & ND \\
\hline Diethyl phthalate, $\mu \mathrm{g} / \mathrm{L}$ & SW8270 & 10 & ND & ND & ND \\
\hline Dimethoate, $\mu \mathrm{g} / \mathrm{L}$ & SW8270 & -. & ND & ND & ND \\
\hline Dimethyl phthalate, $\mu \mathrm{g} / \mathrm{L}$ & SW8270 & 10 & ND & ND & ND \\
\hline Diphenylamine, $\mu \mathrm{g} / \mathrm{L}$ & SW8270 & 10 & ND & ND & ND \\
\hline Disulfoton, $\mu \mathrm{g} / \mathrm{L}$ & SW8270 & 50 & ND & ND & ND \\
\hline Famphur, $\mu \mathrm{g} / \mathrm{L}$ & SW8270 & - & ND & ND & ND \\
\hline Fluoranthene, $\mu \mathrm{g} / \mathrm{L}$ & SW8270 & 10 & ND & ND & ND \\
\hline Fluorene, $\mu \mathrm{g} / \mathrm{L}$ & SW8270 & 10 & ND & ND & ND \\
\hline Hexachlorobenzene, $\mu \mathrm{g} / \mathrm{L}$ & SW8270 & 10 & ND & ND & ND \\
\hline Hexachlorobutadiene, $\mu \mathrm{g} / \mathrm{L}$ & SW8270 & 10 & ND & ND & ND \\
\hline Hexachlorocyclopentadiene, $\mu \mathrm{g} / \mathrm{L}$ & SW8270 & 10 & ND & ND & ND \\
\hline Hexachloroethane, $\mu \mathrm{g} / \mathrm{L}$ & SW8270 & 10 & ND & ND & ND \\
\hline Hexachlorophene, $\mu \mathrm{g} / \mathrm{L}$ & SW8270 & -- & ND & ND & ND \\
\hline Hexachloropropene, $\mu \mathrm{g} / \mathrm{L}$ & SW8270 & 10 & ND & ND & ND \\
\hline Indeno(1,2,3-cd)pyrene, $\mu \mathrm{g} / \mathrm{L}$ & SW8270 & 10 & ND & ND & ND \\
\hline Isophorone, $\mu \mathrm{g} / \mathrm{L}$ & SW8270 & 10 & ND & ND & ND \\
\hline Isosafrole, $\mu \mathrm{g} / \mathrm{L}$ & SW8270 & 20 & ND & ND & ND \\
\hline Methapyrilene, $\mu \mathrm{g} / \mathrm{L}$ & SW8270 & 10 & ND & ND & ND \\
\hline
\end{tabular}


Table 11.--Analytical results of quarterly ground-water monitoring at the Chromic Acid Pit site, U.S. Army Air Defense Artillery Center and Fort Bliss, El Paso, Texas, first quarter, December 1993--Continued

\begin{tabular}{|c|c|c|c|c|c|}
\hline Parameter and unit & Method & $\begin{array}{l}\text { Laboratory } \\
\text { reporting } \\
\text { limit }\end{array}$ & $\begin{array}{l}\text { Well MW1 } \\
\text { result/qualifier }\end{array}$ & $\begin{array}{l}\text { Well MW2 } \\
\text { result/qualifier }\end{array}$ & $\begin{array}{l}\text { Well MW3 } \\
\text { result/qualifier }\end{array}$ \\
\hline \multicolumn{6}{|l|}{$\begin{array}{l}\text { Semivolatile organic compounds-- } \\
\text { Continued: }\end{array}$} \\
\hline Methyl parathion, $\mu \mathrm{g} / \mathrm{L}$ & SW8270 & 50 & ND & ND & ND \\
\hline N-Nitroso-di-n-propylamine, $\mu \mathrm{g} / \mathrm{L}$ & SW8270 & 10 & ND & ND & ND \\
\hline N-Nitroso-di-n-butylamine, $\mu \mathrm{g} / \mathrm{L}$ & SW8270 & 10 & ND & ND & ND \\
\hline N-Nitrosodiethylamine, $\mu \mathrm{g} / \mathrm{L}$ & SW8270 & 10 & ND & ND & ND \\
\hline N-Nitrosodimethylamine, $\mu \mathrm{g} / \mathrm{L}$ & SW8270 & 10 & ND & ND & ND \\
\hline N-Nitrosodiphenylamine, $\mu \mathrm{g} / \mathrm{L}$ & SW8270 & 10 & ND & ND & ND \\
\hline N-Nitrosomethylethylamine, $\mu \mathrm{g} / \mathrm{L}$ & SW8270 & 10 & ND & ND & ND \\
\hline N-Nitrosomorpholine, $\mu \mathrm{g} / \mathrm{L}$ & SW8270 & 10 & ND & ND & ND \\
\hline N-Nitrosopiperidine, $\mu \mathrm{g} / \mathrm{L}$ & SW8270 & 10 & ND & ND & ND \\
\hline N-Nitrosopyrrolidine, $\mu \mathrm{g} / \mathrm{L}$ & SW8270 & 10 & ND & ND & ND \\
\hline Naphthalene, $\mu \mathrm{g} / \mathrm{L}$ & SW8270 & 10 & ND & ND & ND \\
\hline Nitrobenzene, $\mu \mathrm{g} / \mathrm{L}$ & SW8270 & 10 & ND & ND & ND \\
\hline $0,0,0$-Triethylphosphoro-thioate, $\mu \mathrm{g} / \mathrm{L}$ & SW8270 & 10 & ND & ND & ND \\
\hline Parathion, $\mu \mathrm{g} / \mathrm{L}$ & SW8270 & 50 & ND & ND & ND \\
\hline Pentachlorobenzene, $\mu \mathrm{g} / \mathrm{L}$ & SW8270 & 10 & ND & $\mathrm{ND}$ & ND \\
\hline Pentachloroethane, $\mu \mathrm{g} / \mathrm{L}$ & SW8270 & 10 & ND & ND & ND \\
\hline Pentachloronitrobenzene, $\mu \mathrm{g} / \mathrm{L}$ & SW8270 & 50 & ND & ND & ND \\
\hline Pentachlorophenol, $\mu \mathrm{g} / \mathrm{L}$ & SW8270 & 50 & ND & ND & ND \\
\hline Phenacetin, $\mu \mathrm{g} / \mathrm{L}$ & SW8270 & 10 & ND & ND & ND \\
\hline Phenanthrene, $\mu \mathrm{g} / \mathrm{L}$ & SW8270 & 10 & ND & $\mathrm{ND}$ & ND \\
\hline Phenol, $\mu \mathrm{g} / \mathrm{L}$ & SW8270 & 10 & ND & ND & ND \\
\hline Phorate, $\mu \mathrm{g} / \mathrm{L}$ & SW8270 & 100 & ND & ND & ND \\
\hline Pronamide, $\mu \mathrm{g} / \mathrm{L}$ & SW8270 & 10 & ND & ND & ND \\
\hline Pyrene, $\mu \mathrm{g} / \mathrm{L}$ & SW8270 & 10 & ND & ND & ND \\
\hline Pyridine, $\mu \mathrm{g} / \mathrm{L}$ & SW8270 & 20 & ND & ND & ND \\
\hline Safrole, $\mu \mathrm{g} / \mathrm{L}$ & SW8270 & 10 & $\mathrm{ND}$ & ND & ND \\
\hline Sulfotepp, $\mu \mathrm{g} / \mathrm{L}$ & SW8270 & 50 & ND & ND & ND \\
\hline Thionazin, $\mu \mathrm{g} / \mathrm{L}$ & SW8270 & 50 & $\mathrm{ND}$ & ND & ND \\
\hline a,a-Dimethylphenethyl-amine, $\mu \mathrm{g} / \mathrm{L}$ & SW8270 & 10 & $\mathrm{ND}$ & ND & ND \\
\hline bis(2-Chloroethoxy)methane, $\mu \mathrm{g} / \mathrm{L}$ & SW8270 & 10 & ND & ND & ND \\
\hline bis(2-Chloroethyl) ether, $\mu \mathrm{g} / \mathrm{L}$ & SW8270 & 10 & ND & ND & ND \\
\hline bis(2-Chloroisopropyl)ether, $\mu \mathrm{g} / \mathrm{L}$ & SW8270 & 10 & ND & ND & ND \\
\hline bis(2-Ethylhexyl)phthalate, $\mu \mathrm{g} / \mathrm{L}$ & SW8270 & 10 & $\mathrm{ND}$ & ND & ND \\
\hline 1,2,4,5-Tetrachloro-benzene, $\mu \mathrm{g} / \mathrm{L}$ & SW8270 & 10 & ND & ND & ND \\
\hline 1,2,4-Trichlorobenzene, $\mu \mathrm{g} / \mathrm{L}$ & SW8270 & 10 & ND & ND & ND \\
\hline 1,2-Dichlorobenzene, $\mu \mathrm{g} / \mathrm{L}$ & SW8270 & 10 & ND & ND & ND \\
\hline 1,3,5-Trinitrobenzene, $\mu \mathrm{g} / \mathrm{L}$ & SW8270 & 10 & ND & ND & ND \\
\hline 1,3-Dichlorobenzene, $\mu \mathrm{g} / \mathrm{L}$ & SW8270 & 10 & ND & ND & ND \\
\hline 1,3-Dinitrobenzene, $\mu \mathrm{g} / \mathrm{L}$ & SW8270 & 10 & ND & ND & ND \\
\hline 1,4-Dichlorobenzene, $\mu \mathrm{g} / \mathrm{L}$ & SW8270 & 10 & ND & ND & ND \\
\hline
\end{tabular}


Table 11.--Analytical results of quarterly ground-water monitoring at the Chromic Acid Pit site, U.S. Army Air Defense Artillery Center and Fort Bliss, El Paso, Texas, first quarter, December 1993--Continued

\begin{tabular}{|c|c|c|c|c|c|}
\hline Parameter and unit & Method & $\begin{array}{l}\text { Laboratory } \\
\text { reporting } \\
\text { limit }\end{array}$ & $\begin{array}{l}\text { Well MW1 } \\
\text { result/qualifier }\end{array}$ & $\begin{array}{l}\text { Well MW2 } \\
\text { result/qualifier }\end{array}$ & $\begin{array}{l}\text { Well MW3 } \\
\text { result/qualifier }\end{array}$ \\
\hline \multicolumn{6}{|l|}{$\begin{array}{l}\text { Semivolatile organic compounds-- } \\
\text { Continued: }\end{array}$} \\
\hline 1,4-Naphthoquinone, $\mu \mathrm{g} / \mathrm{L}$ & SW8270 & 10 & ND & ND & ND \\
\hline 1-Naphthylamine, $\mu \mathrm{g} / \mathrm{L}$ & SW8270 & 10 & ND & ND & ND \\
\hline 2,3,4,6-Tetrachlorophenol, $\mu \mathrm{g} / \mathrm{L}$ & SW8270 & 50 & ND & ND & ND \\
\hline 2,4,5-Trichlorophenol, $\mu \mathrm{g} / \mathrm{L}$ & SW8270 & 50 & ND & ND & ND \\
\hline 2,4,6-Trichlorophenol, $\mu \mathrm{g} / \mathrm{L}$ & SW8270 & 10 & ND & ND & ND \\
\hline 2,4-Dichlorophenol, $\mu \mathrm{g} / \mathrm{L}$ & SW8270 & 10 & ND & ND & ND \\
\hline 2,4-Dimethylphenol, $\mu \mathrm{g} / \mathrm{L}$ & sW8270 & 10 & ND & ND & ND \\
\hline 2,4-Dinitrophenol, $\mu \mathrm{g} / \mathrm{L}$ & SW8270 & 50 & ND & ND & ND \\
\hline 2,4-Dinitrotoluene, $\mu \mathrm{g} / \mathrm{L}$ & sw8270 & 10 & ND & ND & ND \\
\hline 2,6-Dichlorophenol, $\mu \mathrm{g} / \mathrm{L}$ & sW8270 & 10 & ND & ND & ND \\
\hline 2,6-Dinitrotoluene, $\mu \mathrm{g} / \mathrm{L}$ & SW8270 & 10 & ND & ND & ND \\
\hline 2-Acetylaminofluorene, $\mu \mathrm{g} / \mathrm{L}$ & sW8270 & 100 & ND & ND & ND \\
\hline 2-Chloronaphthalene, $\mu \mathrm{g} / \mathrm{L}$ & SW8270 & 10 & ND & ND & ND \\
\hline 2-Chlorophenol, $\mu \mathrm{g} / \mathrm{L}$ & SW8270 & 10 & ND & ND & ND \\
\hline 2-Methylnaphthalene, $\mu \mathrm{g} / \mathrm{L}$ & SW8270 & 10 & ND & ND & ND \\
\hline 2-Methylphenol, $\mu \mathrm{g} / \mathrm{L}$ & SW8270 & 10 & ND & ND & ND \\
\hline 2-Naphthylamine, $\mu \mathrm{g} / \mathrm{L}$ & SW8270 & 10 & ND & ND & ND \\
\hline 2-Nitroaniline, $\mu \mathrm{g} / \mathrm{L}$ & sW8270 & 50 & ND & ND & ND \\
\hline 2-Nitrophenol, $\mu \mathrm{g} / \mathrm{L}$ & SW8270 & 10 & ND & ND & ND \\
\hline 2-Picoline, $\mu \mathrm{g} / \mathrm{L}$ & SW8270 & 10 & ND & ND & ND \\
\hline 2-Toluidine, $\mu \mathrm{g} / \mathrm{L}$ & SW8270 & 10 & ND & ND & ND \\
\hline 3,3'-Dichlorobenzidine, $\mu \mathrm{g} / \mathrm{L}$ & SW8270 & 20 & ND & ND & ND \\
\hline 3,3'-Dimethylbenzidine, $\mu \mathrm{g} / \mathrm{L}$ & SW8270 & 10 & ND & ND & ND \\
\hline 3-Methylcholanthrene, $\mu \mathrm{g} / \mathrm{L}$ & sW8270 & 10 & ND & ND & ND \\
\hline 3-Nitroaniline, $\mu \mathrm{g} / \mathrm{L}$ & SW8270 & 50 & ND & ND & ND \\
\hline 3/4-Methylphenol, $\mu \mathrm{g} / \mathrm{L}$ & SW8270 & 10 & ND & ND & ND \\
\hline 4,6-Dinitro-2-methylphenol, $\mu \mathrm{g} / \mathrm{L}$ & SW8270 & 50 & ND & ND & ND \\
\hline 4-Aminobiphenyl, $\mu \mathrm{g} / \mathrm{L}$ & SW8270 & 10 & ND & ND & ND \\
\hline 4-Bromophenylphenyl ether, $\mu \mathrm{g} / \mathrm{L}$ & SW8270 & 10 & ND & ND & ND \\
\hline 4-Chioro-3-methylphenol, $\mu \mathrm{g} / \mathrm{L}$ & SW8270 & 10 & ND & ND & ND \\
\hline 4-Chloroaniline, $\mu \mathrm{g} / \mathrm{L}$ & SW8270 & 10 & ND & ND & ND \\
\hline 4-Chiorophenyl phenyl ether, $\mu \mathrm{g} / \mathrm{L}$ & SW8270 & 10 & ND & ND & ND \\
\hline 4-Nitroaniline, $\mu \mathrm{g} / \mathrm{L}$ & sW8270 & 50 & ND & ND & ND \\
\hline 4-Nitrophenol, $\mu \mathrm{g} / \mathrm{L}$ & sw8270 & 50 & ND & ND & ND \\
\hline 4-Nitroquinoline-1-oxide, $\mu \mathrm{g} / \mathrm{L}$ & SW8270 & -- & ND & ND & ND \\
\hline 4-Phenylenediamine, $\mu \mathrm{g} / \mathrm{L}$ & sw8270 & -- & ND & ND & ND \\
\hline 5-Nitro-o-toluidine, $\mu \mathrm{g} / \mathrm{L}$ & sw8270 & 10 & ND & ND & ND \\
\hline 7,12-Dimethylbenz(a)-anthracene, $\mu \mathrm{g} / \mathrm{L}$ & SW8270 & 10 & ND & ND & ND \\
\hline Cyclopentane, ethyl-, $\mu \mathrm{g} / \mathrm{L}$ & SW8270 & - & $4.3 / \mathrm{W}$ & ND & $4.2 / \mathrm{W}, \mathrm{X}$ \\
\hline
\end{tabular}


Table 11.--Analytical results of quarterly ground-water monitoring at the Chromic Acid Pit site, U.S. Army Air Defense Artillery Center and Fort Bliss, El Paso, Texas, first quarter, December 1993--Concluded

\begin{tabular}{|c|c|c|c|c|c|}
\hline Parameter and unit & Method & $\begin{array}{l}\text { Laboratory } \\
\text { reporting } \\
\text { limit }\end{array}$ & $\begin{array}{l}\text { Well MW1 } \\
\text { result/qualifier }\end{array}$ & $\begin{array}{l}\text { Well MW2 } \\
\text { result/qualifier }\end{array}$ & $\begin{array}{l}\text { Well MW3 } \\
\text { result/qualifier }\end{array}$ \\
\hline \multicolumn{6}{|l|}{ Metals: } \\
\hline Antimony, total, $\mathrm{mg} / \mathrm{L}$ & SW6010 & 0.060 & ND & ND & ND \\
\hline Antimony, dissolved, $\mathrm{mg} / \mathrm{L}$ & SW6010 & 0.060 & ND & ND & ND \\
\hline Arsenic, total, $\mathrm{mg} / \mathrm{L}$ & SW7060 & 0.0050 & ND & ND & ND \\
\hline Arsenic, dissolved, mg/L & SW7060 & 0.0050 & ND & ND & ND \\
\hline Barium, total, $\mathrm{mg} / \mathrm{L}$ & SW6010 & 0.010 & 0.040 & 0.045 & 0.056 \\
\hline Barium, dissolved, mg/L & SW6010 & 0.010 & 0.034 & 0.041 & 0.051 \\
\hline Beryllium, total, mg/L & SW6010 & 0.0020 & ND & 0.0023 & 0.0023 \\
\hline Beryllium, dissolved, $\mathrm{mg} / \mathrm{L}$ & SW6010 & 0.0020 & ND & ND & ND \\
\hline Cadmium, total, $\mathrm{mg} / \mathrm{L}$ & SW6010 & 0.0050 & ND & ND & ND \\
\hline Cadmium, dissolved, $\mathrm{mg} / \mathrm{L}$ & SW6010 & 0.0050 & ND & ND & ND \\
\hline Chromium, total, mg/L & SW7191 & 0.0020 & 0.019 & $0.035 / \mathrm{D}$ & $0.022 / \mathrm{D}$ \\
\hline Chromium, dissolved, $\mathrm{mg} / \mathrm{L}$ & SW7191 & 0.0020 & 0.0074 & 0.0071 & 0.0063 \\
\hline Chromium, total, $\mathrm{mg} / \mathrm{L}$ & SW6010 & 0.010 & $0.021 / \mathrm{D}$ & $0.032 / \mathrm{D}$ & $0.017 / \mathrm{D}$ \\
\hline Chromium, dissolved, $\mathrm{mg} / \mathrm{L}$ & SW6010 & 0.010 & ND & ND & ND \\
\hline Chromium (VI), total, $\mathrm{mg} / \mathrm{L}$ & SW7196 & 0.010 & ND & ND & ND \\
\hline Chromium (VI), dissolved, $\mathrm{mg} / \mathrm{L}$ & SW7196 & 0.010 & ND & ND & ND \\
\hline Cobalt, total, $\mathrm{mg} / \mathrm{L}$ & SW6010 & 0.010 & ND & ND & ND \\
\hline Cobalt, dissolved, $\mathrm{mg} / \mathrm{L}$ & SW6010 & 0.010 & ND & ND & ND \\
\hline Copper, total, mg/L & SW6010 & 0.020 & ND & ND & ND \\
\hline Copper, dissolved, mg/L & SW6010 & 0.020 & ND & ND & ND \\
\hline Lead, total, $\mathrm{mg} / \mathrm{L}$ & SW7421 & 0.010 & $\mathrm{ND} / \mathrm{C}, \mathrm{M}, \mathrm{I}$ & $\mathrm{ND} / \mathrm{C}, \mathrm{M}, \mathrm{I}$ & $\mathrm{ND} / \mathrm{C}, \mathrm{M}, \mathrm{I}$ \\
\hline Lead, dissolved, $\mathrm{mg} / \mathrm{L}$ & SW7421 & 0.0050 & $\mathrm{ND} / \mathrm{M}, \mathrm{I}$ & $\mathrm{ND} / \mathrm{M}, \mathrm{I}$ & $\mathrm{ND} / \mathrm{M}, \mathrm{I}$ \\
\hline Mercury, total, mg/L & SW7470 & 0.00020 & ND & ND & ND \\
\hline Mercury, dissolved, mg/L & SW7470 & 0.00020 & ND & ND & ND \\
\hline Nickel, total, mg/L & SW6010 & 0.040 & ND & ND & ND \\
\hline Nickel, dissolved, mg/L & SW6010 & 0.040 & ND & ND & ND \\
\hline Selenium, total, $\mathrm{mg} / \mathrm{L}$ & SW7740 & 0.0050 & ND & ND & ND \\
\hline Selenium, dissolved, $\mathrm{mg} / \mathrm{L}$ & SW7740 & 0.0050 & ND & ND & ND \\
\hline Silver, total, mg/L & SW6010 & 0.010 & ND & ND & ND \\
\hline Silver, dissolved, $\mathrm{mg} / \mathrm{L}$ & SW6010 & 0.010 & ND & ND & ND \\
\hline Thallium, total, $\mathrm{mg} / \mathrm{L}$ & SW7841 & 0.010 & $\mathrm{ND} / \mathrm{C}, \mathrm{M}, \mathrm{I}$ & $\mathrm{ND} / \mathrm{C}, \mathrm{M}, \mathrm{I}$ & $\mathrm{ND} / \mathrm{C}, \mathrm{M}, \mathrm{I}$ \\
\hline Thallium, dissolved, $\mathrm{mg} / \mathrm{L}$ & SW7841 & 0.020 & $\mathrm{ND} / \mathrm{C}, \mathrm{M}, \mathrm{I}$ & $\mathrm{ND} / \mathrm{C}, \mathrm{M}, \mathrm{I}$ & $\mathrm{ND} / \mathrm{C}, \mathrm{M}, \mathrm{I}$ \\
\hline Tin, total, $\mathrm{mg} / \mathrm{L}$ & SW6010 & 0.10 & $\mathrm{ND} / \mathrm{C}$ & $\mathrm{ND} / \mathrm{C}$ & $\mathrm{ND} / \mathrm{C}$ \\
\hline Tin, dissolved, $\mathrm{mg} / \mathrm{L}$ & SW6010 & 0.10 & $\mathrm{ND} / \mathrm{C}$ & $\mathrm{ND} / \mathrm{C}$ & $\mathrm{ND} / \mathrm{C}$ \\
\hline Vanadium, total, $\mathrm{mg} / \mathrm{L}$ & SW6010 & 0.010 & 0.016 & 0.015 & 0.014 \\
\hline Vanadium, dissolved, $\mathrm{mg} / \mathrm{L}$ & SW6010 & 0.010 & 0.015 & 0.016 & 0.013 \\
\hline Zinc, total, $\mathrm{mg} / \mathrm{L}$ & SW6010 & 0.020 & 0.072 & 0.22 & 0.056 \\
\hline Zinc, dissolved, $\mathrm{mg} / \mathrm{L}$ & SW6010 & 0.020 & ND & ND & ND \\
\hline Sulfide, total, $\mathrm{mg} / \mathrm{L}$ & E376.2 & 0.050 & ND & ND & ND \\
\hline Cyanide, $\mathrm{mg} / \mathrm{L}$ & SW9012 & 0.010 & ND & ND & ND \\
\hline Total petroleum hydrocarbons, $\mathrm{mg} / \mathrm{L}$ & E418.1 & 1.0 & ND & ND & ND \\
\hline
\end{tabular}


Table 12.--Analytical results of quarterly ground-water monitoring at the Chromic Acid Pit site, U.S. Army Air Defense Artillery Center and Fort Bliss, El Paso, Texas, second quarter, March 1994

[Qualifier codes are identified in table 15. --, no data; NTU's, nephelometric turbidity units; $\mu \mathrm{S} / \mathrm{cm}$, microsiemens per centimeter at 25 degrees Celsius; $\mathrm{mg} / \mathrm{L}$, milligrams per liter, $\mu \mathrm{g} / \mathrm{L}$, micrograms per liter; ND, not detected

\begin{tabular}{|c|c|c|c|c|c|}
\hline Parameter and unit & Method & $\begin{array}{l}\text { Laboratory } \\
\text { reporting } \\
\text { limit }\end{array}$ & $\begin{array}{l}\text { Well MW1 } \\
\text { result/qualifier }\end{array}$ & $\begin{array}{l}\text { Well MW2 } \\
\text { result/qualifier }\end{array}$ & $\begin{array}{l}\text { Well MW3 } \\
\text { result/qualifier }\end{array}$ \\
\hline Date & -- & - & 08-Mar-94 & 09-Mar-94 & 10-Mar-94 \\
\hline Time & -- & -- & 1400 & 1415 & 1315 \\
\hline U.S. Geological Survey sample number & -- & -- & CAP1007 & CAP2005 & CAP3005 \\
\hline Laboratory sample number & -- & -- & $034181-0001-\mathrm{SA}$ & $034181-0004-\mathrm{SA}$ & $034181-0007-S A$ \\
\hline $\begin{array}{l}\text { Water level, elevation, feet above sea } \\
\text { level, prior to pumping }\end{array}$ & -- & 0.01 & $3,609.65$ & $3,609.51$ & $3,609.28$ \\
\hline $\begin{array}{l}\text { Amount purged prior to sampling, } \\
\text { gallons }\end{array}$ & -- & 1 & 211 & 188 & 184.5 \\
\hline Depth sampled, feet below land surface & -- & 1 & 330 & 330 & 330 \\
\hline \multicolumn{6}{|l|}{ Field properties: } \\
\hline Temperature, degrees Celsius & E170.1 & 0.1 & 23.0 & 23.0 & 23.5 \\
\hline Turbidity, NTU's & E180.1 & 1 & 30.1 & 25.2 & 122 \\
\hline $\mathrm{pH}$ & E150.1 & 0.1 & 9.09 & 7.98 & 7.97 \\
\hline Specific conductance, $\mu \mathrm{S} / \mathrm{cm}$ & E120.1 & 10.0 & 747 & 780 & 800 \\
\hline Alkalinity, carbonate, $\mathrm{mg} / \mathrm{L}$ & A403 & -- & 12 & 0 & 0 \\
\hline Alkalinity, bicarbonate, $\mathrm{mg} / \mathrm{L}$ & A403 & 10 & 154 & 229 & 244 \\
\hline Alkalinity, calcium carbonate, mg/L & A403 & 10 & 146 & 188 & 200 \\
\hline Dissolved solids, mg/L & E160.1 & 10.0 & 459 & 518 & 564 \\
\hline Suspended solids, mg/L & E160.2 & 2.0 & 47.2 & $21.6 / \mathrm{D}$ & 219 \\
\hline \multicolumn{6}{|l|}{ Common ions: } \\
\hline Chloride, total, $\mathrm{mg} / \mathrm{L}$ & E300 & 0.50 & 81.6 & 65.4 & 68.3 \\
\hline Fluoride, total, mg/L & E300 & 0.50 & 1.5 & 1.3 & 1.2 \\
\hline Nitrate as nitrogen, total, $\mathrm{mg} / \mathrm{L}$ & E300 & 0.50 & 2.1 & 2.7 & 2.5 \\
\hline $\begin{array}{l}\text { Nitrite plus nitrate as nitrogen, total, } \\
\mathrm{mg} / \mathrm{L}\end{array}$ & E353.2 & 0.10 & 2.3 & 3.0 & 2.7 \\
\hline $\begin{array}{l}\text { Orthophosphate as phosphorus, total, } \\
\mathrm{mg} / \mathrm{L}\end{array}$ & E300 & 0.50 & ND & ND & ND \\
\hline Sulfate, total, $\mathrm{mg} / \mathrm{L}$ & E300 & 0.50 & 102 & 101 & 104 \\
\hline Calcium, total, mg/L & SW6010 & 5.0 & 23.4 & 30.3 & 31.8 \\
\hline Calcium, dissolved, $\mathrm{mg} / \mathrm{L}$ & SW6010 & 5.0 & 15.5 & 29.4 & 25.1 \\
\hline Magnesium, total, mg/L & SW6010 & 5.0 & 8.9 & 10.7 & 11.8 \\
\hline Magnesium, dissolved, $\mathrm{mg} / \mathrm{L}$ & SW6010 & 5.0 & 8.6 & 10.9 & 10.0 \\
\hline Potassium, total, $\mathrm{mg} / \mathrm{L}$ & SW6010 & 5.0 & 8.9 & 9.1 & 9.6 \\
\hline Potassium, dissolved, $\mathrm{mg} / \mathrm{L}$ & SW6010 & 5.0 & 8.9 & 9.5 & 8.0 \\
\hline Sodium, total, mg/L & SW6010 & 5.0 & 121 & 141 & 129 \\
\hline Sodium, dissolved, $\mathrm{mg} / \mathrm{L}$ & SW6010 & 5.0 & 120 & 141 & 120 \\
\hline \multicolumn{6}{|l|}{ Metals: } \\
\hline Aluminum, total, $\mathrm{mg} / \mathrm{L}$ & SW6010 & 0.20 & $0.79 / \mathrm{M}, \mathrm{H}$ & $0.71 / \mathrm{M}, \mathrm{H}$ & $6.0 / \mathrm{M}, \mathrm{H}, \mathrm{R}$ \\
\hline Aluminum, dissolved, mg/L & SW6010 & 0.20 & ND & ND & ND \\
\hline Antimony, total, $\mathrm{mg} / \mathrm{L}$ & SW6010 & 0.20 & ND & ND & ND \\
\hline
\end{tabular}


Table 12.--Analytical results of quarterly ground-water monitoring at the Chromic Acid Pit site, U.S. Army Air Defense Artillery Center and Fort Bliss, El Paso, Texas, second quarter, March 1994--Concluded

\begin{tabular}{|c|c|c|c|c|c|}
\hline Parameter and unit & Method & $\begin{array}{l}\text { Laboratory } \\
\text { reporting } \\
\text { limit }\end{array}$ & $\begin{array}{l}\text { Well MW1 } \\
\text { result/qualifier }\end{array}$ & $\begin{array}{l}\text { Well MW2 } \\
\text { result/qualifier }\end{array}$ & $\begin{array}{l}\text { Well MW3 } \\
\text { result/qualifier }\end{array}$ \\
\hline \multicolumn{6}{|l|}{ Metals-Continued: } \\
\hline Antimony, dissolved, $\mathrm{mg} / \mathrm{L}$ & SW6010 & 0.20 & ND & ND & ND \\
\hline Arsenic, total, mg/L & SW6010 & 0.30 & ND & ND & ND \\
\hline Arsenic, dissolved, $\mathrm{mg} / \mathrm{L}$ & SW6010 & 0.30 & ND & ND & ND \\
\hline Barium, total, mg/L & SW6010 & 0.10 & ND & ND & ND \\
\hline Barium, dissolved, $\mathrm{mg} / \mathrm{L}$ & SW6010 & 0.10 & ND & ND & ND \\
\hline Beryllium, total, mg/L & SW6010 & 0.0020 & ND & ND & ND \\
\hline Beryllium, dissolved, $\mathrm{mg} / \mathrm{L}$ & SW6010 & 0.0020 & ND & ND & ND \\
\hline Cadmium, total, $\mathrm{mg} / \mathrm{L}$ & SW6010 & 0.0050 & ND & ND & ND \\
\hline Cadmium, dissolved, $\mathrm{mg} / \mathrm{L}$ & SW6010 & 0.0050 & ND & ND & ND \\
\hline Chromium, total, mg/L & SW7191 & 0.0020 & 0.038 & $0.032 / \mathrm{D}$ & 0.092 \\
\hline Chromium, dissolved, $\mathrm{mg} / \mathrm{L}$ & SW7191 & 0.0020 & 0.0082 & 0.0080 & 0.0068 \\
\hline Cobalt, total, mg/L & SW6010 & 0.040 & ND & ND & ND \\
\hline Cobalt, dissolved, $\mathrm{mg} / \mathrm{L}$ & SW6010 & 0.040 & ND & ND & ND \\
\hline Copper, total, $\mathrm{mg} / \mathrm{L}$ & SW6010 & 0.030 & ND & ND & ND \\
\hline Copper, dissolved, $\mathrm{mg} / \mathrm{L}$ & SW6010 & 0.030 & ND & ND & ND \\
\hline Iron, total, $\mathrm{mg} / \mathrm{L}$ & SW6010 & 0.040 & $0.78 / \mathrm{M}, \mathrm{H}$ & $0.76 / \mathrm{M}, \mathrm{H}$ & $5.4 / \mathrm{E}, \mathrm{M}, \mathrm{H}$ \\
\hline Iron, dissolved, $\mathrm{mg} / \mathrm{L}$ & SW6010 & 0.040 & ND & ND & ND \\
\hline Lead, total, mg/L & SW6010 & 0.20 & ND & ND & ND \\
\hline Lead, dissolved, mg/L & SW6010 & 0.20 & ND & ND & ND \\
\hline Manganese, total, $\mathrm{mg} / \mathrm{L}$ & SW6010 & 0.010 & 0.013 & 0.029 & 0.11 \\
\hline Manganese, dissolved, $\mathrm{mg} / \mathrm{L}$ & SW6010 & 0.010 & ND & ND & ND \\
\hline Molybdenum, total, $\mathrm{mg} / \mathrm{L}$ & SW6010 & 0.040 & ND & ND & ND \\
\hline Molybdenum, dissolved, $\mathrm{mg} / \mathrm{L}$ & SW6010 & 0.040 & ND & ND & ND \\
\hline Nickel, total, mg/L & SW6010 & 0.040 & ND & ND & 0.063 \\
\hline Nickel, dissolved, mg/L & SW6010 & 0.040 & ND & ND & ND \\
\hline Selenium, total, $\mathrm{mg} / \mathrm{L}$ & SW6010 & 0.40 & $\mathrm{ND} / \mathrm{M}, \mathrm{I}$ & $\mathrm{ND} / \mathrm{M}, \mathrm{I}$ & $\mathrm{ND} / \mathrm{M}, \mathrm{I}$ \\
\hline Selenium, dissolved, $\mathrm{mg} / \mathrm{L}$ & SW6010 & 0.40 & ND & ND & ND \\
\hline Silver, total, mg/L & SW6010 & 0.030 & ND & ND & ND \\
\hline Silver, dissolved, $\mathrm{mg} / \mathrm{L}$ & SW6010 & 0.030 & $\mathrm{ND} / \mathrm{M}, \mathrm{l}$ & $\mathrm{ND} / \mathrm{M}, \mathrm{l}$ & $\mathrm{ND} / \mathrm{M}, \mathrm{I}$ \\
\hline Thallium, total, mg/L & SW6010 & 5.0 & ND & ND & ND \\
\hline Thallium, dissolved, $\mathrm{mg} / \mathrm{L}$ & SW6010 & 5.0 & ND & ND & ND \\
\hline Vanadium, total, $\mathrm{mg} / \mathrm{L}$ & SW6010 & 0.040 & ND & ND & ND \\
\hline Vanadium, dissolved, $\mathrm{mg} / \mathrm{L}$ & SW6010 & 0.040 & ND & ND & ND \\
\hline Zinc, total, mg/L & SW6010 & 0.010 & $0.015 / \mathrm{D}$ & $0.13 / \mathrm{D}$ & 0.077 \\
\hline Zinc, dissolved, $\mathrm{mg} / \mathrm{L}$ & SW6010 & 0.010 & ND & ND & ND \\
\hline Total petroleum hydrocarbons, $\mathrm{mg} / \mathrm{L}$ & E418.1 & 1.0 & - & - & - \\
\hline Total organic carbon, $\mathrm{mg} / \mathrm{L}$ & E415.1 & 1.0 & $1.3 / \mathrm{M}, \mathrm{H}$ & ND & ND \\
\hline Total organic halogen as chloride, $\mu \mathrm{g} / \mathrm{L}$ & SW9020 & 30.0 & $104 / \mathrm{D}, \mathrm{M}, \mathrm{H}$ & $59.4 / D, M, H$ & ND \\
\hline
\end{tabular}


Table 13.--Analytical results of quarterly ground-water monitoring at the Chromic Acid Pit site, U.S. Army Air Defense Artillery Center and Fort Bliss, El Paso, Texas, third quarter, June 1994

[Qualifier codes are identified in table 15. --, no data; NTU's, nephelometric turbidity units; $\mu \mathrm{S} / \mathrm{cm}$, microsiemens per centimeter at 25 degrees Celsius; $\mathrm{mg} / \mathrm{L}$, milligrams per liter, $\mu \mathrm{g} / \mathrm{L}$, micrograms per liter; ND, not detected]

\begin{tabular}{|c|c|c|c|c|c|}
\hline Parameter and unit & Method & $\begin{array}{l}\text { Laboratory } \\
\text { reporting } \\
\text { limit }\end{array}$ & $\begin{array}{l}\text { Well MW1 } \\
\text { result/qualifier }\end{array}$ & $\begin{array}{l}\text { Well MW2 } \\
\text { result/qualifier }\end{array}$ & $\begin{array}{c}\text { Well MW3 } \\
\text { result/qualifier }\end{array}$ \\
\hline Date & -- & -- & 07-June-94 & 08-June-94 & 09-June-94 \\
\hline Time & .- & -- & 1200 & 1420 & 1345 \\
\hline U.S. Geological Survey sample number & -- & -- & CAP0109 & CAP0209 & CAP0307 \\
\hline Laboratory sample number & -- & -- & 035988-0001-SA & 035988-0004-SA & 035988-0007-SA \\
\hline $\begin{array}{l}\text { Water level, elevation, feet above sea } \\
\text { level, prior to pumping }\end{array}$ & -- & 0.01 & $3,609.85$ & $3,609.73$ & $3,609.56$ \\
\hline $\begin{array}{l}\text { Amount purged prior to sampling, } \\
\text { gallons }\end{array}$ & -- & 1 & 204.5 & 177.5 & 173.5 \\
\hline Depth sampled, feet below land surface & -- & 1 & 320 & 320 & 320 \\
\hline \multicolumn{6}{|l|}{ Field properties: } \\
\hline Temperature, degrees Celsius & E170.1 & 0.1 & 25.0 & 25.0 & 25.0 \\
\hline Turbidity, NTU's & E180.1 & 1 & 5.73 & 10.9 & 29.4 \\
\hline $\mathrm{pH}$ & E150.1 & 0.1 & 8.36 & 7.94 & 7.96 \\
\hline Specific conductance, $\mu \mathrm{S} / \mathrm{cm}$ & E120.1 & 10.0 & 815 & 812 & 829 \\
\hline Alkalinity, carbonate, $\mathrm{mg} / \mathrm{L}$ & A403 & -- & 18 & 0 & 0 \\
\hline Alkalinity, bicarbonate, $\mathrm{mg} / \mathrm{L}$ & A403 & 10 & 161 & 233 & 236 \\
\hline Alkalinity, calcium carbonate, $\mathrm{mg} / \mathrm{L}$ & A403 & 10 & 162 & 191 & 193 \\
\hline Dissolved solids, mg/L & E160.1 & 10.0 & 476 & 515 & 512 \\
\hline Suspended solids, mg/L & E160.2 & 2.0 & $5.2 / \mathrm{M}, \mathrm{I}$ & $5.2 / D, M, I$ & $24 / D, M, I$ \\
\hline \multicolumn{6}{|l|}{ Common ions: } \\
\hline Chloride, total, mg/L & E300 & 0.50 & 81.1 & 65.8 & 67.8 \\
\hline Fluoride, total, mg/L & E300 & 0.50 & 1.4 & 1.2 & 1.2 \\
\hline Nitrate as nitrogen, total, $\mathrm{mg} / \mathrm{L}$ & E300 & 0.50 & 2.2 & 2.6 & 2.5 \\
\hline $\begin{array}{l}\text { Nitrite plus nitrate as nitrogen, total, } \\
\mathrm{mg} / \mathrm{L}\end{array}$ & E353.2 & 0.050 & 2.3 & 2.8 & 2.7 \\
\hline $\begin{array}{l}\text { Orthophosphate as phosphorus, total, } \\
\mathrm{mg} / \mathrm{L}\end{array}$ & E300 & 0.50 & ND & ND & ND \\
\hline Sulfate, total, $\mathrm{mg} / \mathrm{L}$ & E300 & 0.50 & ${ }^{1} 1,000 / D, R$ & 100 & 103 \\
\hline Calcium, total, $\mathrm{mg} / \mathrm{L}$ & SW6010 & 5.0 & 27.5 & 29.5 & 28.7 \\
\hline Calcium, dissolved, mg/L & SW6010 & 5.0 & 28.1 & 28.5 & 30.4 \\
\hline Magnesium, total, $\mathrm{mg} / \mathrm{L}$ & SW6010 & 5.0 & 11.5 & 11.4 & 10.5 \\
\hline Magnesium, dissolved, $\mathrm{mg} / \mathrm{L}$ & SW6010 & 5.0 & 11.8 & 11.2 & 11.3 \\
\hline Potassium, total, $\mathrm{mg} / \mathrm{L}$ & SW6010 & 5.0 & 8.7 & 8.4 & 8.8 \\
\hline Potassium, dissolved, $\mathrm{mg} / \mathrm{L}$ & SW6010 & 5.0 & 8.8 & 8.0 & 9.3 \\
\hline Sodium, total, mg/L & SW6010 & 5.0 & 130 & 138 & 131 \\
\hline Sodium, dissolved, mg/L & SW6010 & 5.0 & 131 & 133 & 137 \\
\hline \multicolumn{6}{|l|}{ Metals: } \\
\hline Aluminum, total, $\mathrm{mg} / \mathrm{L}$ & SW6010 & 0.20 & ND & ND & $0.71 / \mathrm{D}$ \\
\hline Aluminum, dissolved, $\mathrm{mg} / \mathrm{L}$ & SW6010 & 0.20 & ND & ND & ND/D \\
\hline Antimony, total, $\mathrm{mg} / \mathrm{L}$ & SW6010 & 0.20 & ND & ND & ND \\
\hline
\end{tabular}


Table 13.--Analytical results of quarterly ground-water monitoring at the Chromic Acid Pit site, U.S. Army Air Defense Artillery Center and Fort Bliss, El Paso, Texas, third quarter, June 1994--Concluded

\begin{tabular}{|c|c|c|c|c|c|}
\hline Parameter and unit & Method & $\begin{array}{l}\text { Laboratory } \\
\text { reporting } \\
\text { limit }\end{array}$ & $\begin{array}{l}\text { Well MW1 } \\
\text { result/qualifier }\end{array}$ & $\begin{array}{l}\text { Well MW2 } \\
\text { result/qualifier }\end{array}$ & $\begin{array}{l}\text { Well MW3 } \\
\text { result/qualifier }\end{array}$ \\
\hline \multicolumn{6}{|l|}{ Metals-Continued: } \\
\hline Antimony, dissolved, mg/L & SW6010 & 0.20 & ND & ND & ND \\
\hline Arsenic, total, mg/L & SW6010 & 0.30 & ND & ND & ND \\
\hline Arsenic, dissolved, mg/L & SW6010 & 0.30 & ND & ND & ND \\
\hline Barium, total, $\mathrm{mg} / \mathrm{L}$ & SW6010 & 0.10 & ND & ND & ND \\
\hline Barium, dissolved, $\mathrm{mg} / \mathrm{L}$ & SW6010 & 0.10 & ND & ND & ND \\
\hline Beryllium, total, mg/L & SW6010 & 0.0020 & ND & ND & ND \\
\hline Beryllium, dissolved, $\mathrm{mg} / \mathrm{L}$ & SW6010 & 0.0020 & ND & ND & ND \\
\hline Cadmium, total, $\mathrm{mg} / \mathrm{L}$ & SW6010 & 0.0050 & ND & ND & ND \\
\hline Cadmium, dissolved, mg/L & SW6010 & 0.0050 & ND & ND & ND \\
\hline Chromium, total, mg/L & SW7191 & 0.0020 & $0.013 / \mathrm{D}$ & 0.0099 & $0.023 / \mathrm{D}$ \\
\hline Chromium, dissolved, $\mathrm{mg} / \mathrm{L}$ & SW7191 & 0.0020 & 0.0076 & $0.0076 / \mathrm{D}$ & $0.0077 / \mathrm{D}$ \\
\hline Cobalt, total, $\mathrm{mg} / \mathrm{L}$ & SW6010 & 0.040 & ND & ND & ND \\
\hline Cobalt, dissolved, $\mathrm{mg} / \mathrm{L}$ & SW6010 & 0.040 & ND & ND & ND \\
\hline Copper, total, mg/L & SW6010 & 0.030 & ND & ND & ND \\
\hline Copper, dissolved, $\mathrm{mg} / \mathrm{L}$ & SW6010 & 0.030 & ND & ND & ND \\
\hline Iron, total, $\mathrm{mg} / \mathrm{L}$ & SW6010 & 0.040 & $0.066 / \mathrm{D}$ & $0.060 / \mathrm{D}$ & $0.62 / \mathrm{D}$ \\
\hline Iron, dissolved, $\mathrm{mg} / \mathrm{L}$ & SW6010 & 0.040 & $\mathrm{ND} / \mathrm{M}, \mathrm{I}$ & $\mathrm{ND} / \mathrm{M}, \mathrm{I}$ & $0.94 / \mathrm{M}, \mathrm{I}$ \\
\hline Lead, total, mg/L & SW6010 & 0.20 & ND & ND & ND \\
\hline Lead, dissolved, $\mathrm{mg} / \mathrm{L}$ & SW6010 & 0.20 & ND & ND & ND \\
\hline Manganese, total, mg/L & SW6010 & 0.010 & ND/E & ND & 0.022 \\
\hline Manganese, dissolved, $\mathrm{mg} / \mathrm{L}$ & SW6010 & 0.010 & ND & ND & $0.016 / D$ \\
\hline Molybdenum, total, $\mathrm{mg} / \mathrm{L}$ & SW6010 & 0.040 & ND & ND & ND \\
\hline Molybdenum, dissolved, $\mathrm{mg} / \mathrm{L}$ & SW6010 & 0.040 & ND & ND & ND \\
\hline Nickel, total, mg/L & SW6010 & 0.040 & ND & ND & ND \\
\hline Nickel, dissolved, mg/L & SW6010 & 0.040 & ND & ND & ND \\
\hline Selenium, total, $\mathrm{mg} / \mathrm{L}$ & SW6010 & 0.40 & $\mathrm{ND} / \mathrm{M}, \mathrm{I}$ & $\mathrm{ND} / \mathrm{M}, \mathrm{I}$ & $\mathrm{ND} / \mathrm{M}, \mathrm{I}$ \\
\hline Selenium, dissolved, $\mathrm{mg} / \mathrm{L}$ & SW6010 & 0.40 & ND & ND & ND \\
\hline Silver, total, mg/L & SW6010 & 0.030 & ND & ND & ND \\
\hline Silver, dissolved, mg/L & SW6010 & 0.030 & ND & ND & ND \\
\hline Thallium, total, mg/L & SW6010 & 5.0 & $\mathrm{ND} / \mathrm{C}, \mathrm{M}, \mathrm{I}$ & $\mathrm{ND} / \mathrm{C}, \mathrm{M}, \mathrm{I}$ & $\mathrm{ND} / \mathrm{C}, \mathrm{M}, \mathrm{I}$ \\
\hline Thallium, dissolved, mg/L & SW6010 & 5.0 & ND/C & $\mathrm{ND} / \mathrm{C}$ & $\mathrm{ND} / \mathrm{C}$ \\
\hline Vanadium, total, $\mathrm{mg} / \mathrm{L}$ & SW6010 & 0.040 & ND & ND & ND \\
\hline Vanadium, dissolved, $\mathrm{mg} / \mathrm{L}$ & SW6010 & 0.040 & ND & ND & ND \\
\hline Zinc, total, mg/L & SW6010 & 0.010 & $0.019 / \mathrm{E}$ & 0.046 & $0.037 / \mathrm{D}$ \\
\hline Zinc, dissolved, $\mathrm{mg} / \mathrm{L}$ & SW6010 & 0.010 & ND & ND & $0.027 / D$ \\
\hline Total petroleum hydrocarbons, mg/L & E418.1 & 1.0 & ND & ND & ND \\
\hline Total organic carbon, mg/L & SW9060 & 1.0 & $\mathrm{ND} / \mathrm{C}$ & $1.7 / \mathrm{D}$ & $1.4 / \mathrm{D}$ \\
\hline Total organic halogen as chloride, $\mu \mathrm{g} / \mathrm{L}$ & SW9020 & 30.0 & ND & ND & ND \\
\hline
\end{tabular}

${ }^{1}$ Laboratory reporting limit is $2.5 \mathrm{mg} / \mathrm{L}$. 
Table 14.--Analytical results of quarterly ground-water monitoring at the Chromic Acid Pit site, U.S. Army Air Defense Artillery Center and Fort Bliss, El Paso, Texas, fourth quarter, September 1994

[Qualifier codes are identified in table 15. --, no data; NTU's, nephelometric turbidity units; $\mu \mathrm{S} / \mathrm{cm}$, microsiemens per centimeter at 25 degrees Celsius; $\mathrm{mg} / \mathrm{L}$, milligrams per liter, $\mu \mathrm{g} / \mathrm{L}$, micrograms per liter; ND, not detected]

\begin{tabular}{|c|c|c|c|c|c|}
\hline Parameter and unit & Method & $\begin{array}{l}\text { Laboratory } \\
\text { reporting } \\
\text { limit }\end{array}$ & $\begin{array}{l}\text { Well MW1 } \\
\text { result/qualifier }\end{array}$ & $\begin{array}{l}\text { Well MW2 } \\
\text { result/qualifier }\end{array}$ & $\begin{array}{l}\text { Well MW3 } \\
\text { result/qualifier }\end{array}$ \\
\hline Date & - & - & 13-Sept-94 & 14-Sept-94 & 15-Sept-94 \\
\hline Time & -- & -- & 1015 & 1130 & 1415 \\
\hline U.S. Geological Survey sample number & -- & -- & CAP0111 & CAP0211 & CAP0311 \\
\hline Laboratory sample number & -- & -- & 037955-0001-SA & 037978-0001-SA & $038003-0004-S A$ \\
\hline $\begin{array}{l}\text { Water level, elevation, feet above sea } \\
\text { level, prior to pumping }\end{array}$ & -- & 0.01 & $3,608.98$ & $3,608.87$ & $3,608.90$ \\
\hline $\begin{array}{l}\text { Amount purged prior to sampling, } \\
\text { gallons }\end{array}$ & -- & 1 & 211.5 & 180 & 180 \\
\hline Depth sampled, feet below land surface & -- & 1 & 318 & 315 & 318 \\
\hline \multicolumn{6}{|l|}{ Field properties: } \\
\hline Temperature, degrees Celsius & E170.1 & 0.1 & 24.5 & 24.0 & 24.0 \\
\hline Turbidity, NTU's & E180.1 & 1 & 6.07 & 12.4 & 35.2 \\
\hline $\mathrm{pH}$ & E150.1 & 0.1 & 8.22 & 7.86 & 7.79 \\
\hline Specific conductance, $\mu \mathrm{S} / \mathrm{cm}$ & E120.1 & 10.0 & 825 & 817 & 834 \\
\hline Alkalinity, carbonate, mg/L & A403 & -- & 0 & 0 & 0 \\
\hline Alkalinity, bicarbonate, $\mathrm{mg} / \mathrm{L}$ & A403 & 10 & 193 & 228 & 234 \\
\hline Alkalinity, calcium carbonate, $\mathrm{mg} / \mathrm{L}$ & $\mathrm{A} 403$ & 10 & 158 & 187 & 192 \\
\hline Dissolved solids, mg/L & E160.1 & 10.0 & 488/M,I & $484 / \mathrm{M}, \mathrm{I}$ & $500 / \mathrm{M}, \mathrm{I}$ \\
\hline Suspended solids, $\mathrm{mg} / \mathrm{L}$ & E160.2 & 2.0 & $6.0 / \mathrm{D}$ & 12.8 & $42.8 / \mathrm{D}$ \\
\hline \multicolumn{6}{|l|}{ Common ions: } \\
\hline Chloride, total, $\mathrm{mg} / \mathrm{L}$ & E300 & 0.50 & 80.3 & 68.3 & 72.4 \\
\hline Fluoride, total, mg/L & E300 & 0.50 & 1.5 & 1.3 & 1.4 \\
\hline Nitrate as nitrogen, total, $\mathrm{mg} / \mathrm{L}$ & E300 & 0.50 & 2.1 & 2.6 & 2.5 \\
\hline $\begin{array}{l}\text { Nitrite plus nitrate as nitrogen, total, } \\
\mathrm{mg} / \mathrm{L}\end{array}$ & E353.2 & 0.10 & $2.7 / \mathrm{M}, \mathrm{I}$ & $2.9 / \mathrm{M}, \mathrm{I}$ & $3.0 / \mathrm{M}, \mathrm{I}$ \\
\hline $\begin{array}{l}\text { Orthophosphate as phosphorus, total, } \\
\mathrm{mg} / \mathrm{L}\end{array}$ & E300 & 0.50 & ND & ND & ND \\
\hline Sulfate, total, $\mathrm{mg} / \mathrm{L}$ & E300 & 0.50 & 104 & 104 & 106 \\
\hline Calcium, total, $\mathrm{mg} / \mathrm{L}$ & SW6010 & 5.0 & 25.2 & 27.1 & 29.2 \\
\hline Calcium, dissolved, $\mathrm{mg} / \mathrm{L}$ & SW6010 & 5.0 & 26.8 & 28.1 & 27.0 \\
\hline Magnesium, total, $\mathrm{mg} / \mathrm{L}$ & SW6010 & 5.0 & 10.2 & 10.4 & 10.8 \\
\hline Magnesium, dissolved, $\mathrm{mg} / \mathrm{L}$ & SW6010 & 5.0 & 11.1 & 11.0 & 10.4 \\
\hline Potassium, total, $\mathrm{mg} / \mathrm{L}$ & SW6010 & 5.0 & 8.5 & 7.3 & 9.1 \\
\hline Potassium, dissolved, $\mathrm{mg} / \mathrm{L}$ & SW6010 & 5.0 & 9.5 & 8.1 & 9.5 \\
\hline Sodium, total, $\mathrm{mg} / \mathrm{L}$ & SW6010 & 5.0 & 119 & 119 & 129 \\
\hline Sodium, dissolved, $\mathrm{mg} / \mathrm{L}$ & SW6010 & 5.0 & 131 & 128 & 130 \\
\hline \multicolumn{6}{|l|}{ Metals: } \\
\hline Aluminum, total, $\mathrm{mg} / \mathrm{L}$ & SW6010 & 0.20 & ND & 0.27 & $0.68 / \mathrm{D}$ \\
\hline Aluminum, dissolved, $\mathrm{mg} / \mathrm{L}$ & SW6010 & 0.20 & ND & ND & ND \\
\hline Antimony, total, $\mathrm{mg} / \mathrm{L}$ & SW6010 & 0.20 & ND & ND & ND \\
\hline
\end{tabular}


Table 14.--Analytical results of quarterly ground-water monitoring at the Chromic Acid Pit site, U.S. Army Air Defense Artillery Center and Fort Bliss, El Paso, Texas, fourth quarter, September 1994--Concluded

\begin{tabular}{|c|c|c|c|c|c|}
\hline Parameter and unit & Method & $\begin{array}{l}\text { Laboratory } \\
\text { reporting } \\
\text { limit }\end{array}$ & $\begin{array}{l}\text { Well MW1 } \\
\text { result /qualifier }\end{array}$ & $\begin{array}{l}\text { Well MW2 } \\
\text { result/qualifier }\end{array}$ & $\begin{array}{l}\text { Well MW3 } \\
\text { result/qualifier }\end{array}$ \\
\hline \multicolumn{6}{|l|}{ Metals-Continued: } \\
\hline Antimony, dissolved, $\mathrm{mg} / \mathrm{L}$ & SW6010 & 0.20 & ND & ND & ND \\
\hline Arsenic, total, mg/L & SW6010 & 0.30 & ND & ND & ND \\
\hline Arsenic, dissolved, $\mathrm{mg} / \mathrm{L}$ & SW6010 & 0.30 & ND & ND & ND \\
\hline Barium, total, $\mathrm{mg} / \mathrm{L}$ & SW6010 & 0.10 & ND & ND & ND \\
\hline Barium, dissolved, $\mathrm{mg} / \mathrm{L}$ & SW6010 & 0.10 & ND & ND & ND \\
\hline Beryllium, total, $\mathrm{mg} / \mathrm{L}$ & SW6010 & 0.0020 & ND & ND & ND \\
\hline Beryllium, dissolved, $\mathrm{mg} / \mathrm{L}$ & SW6010 & 0.0020 & ND & ND & ND \\
\hline Cadmium, total, $\mathrm{mg} / \mathrm{L}$ & SW6010 & 0.0050 & ND & ND & ND \\
\hline Cadmium, dissolved, $\mathrm{mg} / \mathrm{L}$ & SW6010 & 0.0050 & ND & ND & ND \\
\hline Chromium, total, $\mathrm{mg} / \mathrm{L}$ & SW7191 & 0.0020 & $0.060 / \mathrm{D}$ & 0.034 & 0.039 \\
\hline Chromium, dissolved, $\mathrm{mg} / \mathrm{L}$ & SW7191 & 0.0020 & 0.0094 & 0.0088 & $0.0084 / \mathrm{D}$ \\
\hline Cobalt, total, mg/L & SW6010 & 0.040 & ND & ND & ND \\
\hline Cobalt, dissolved, $\mathrm{mg} / \mathrm{L}$ & SW6010 & 0.040 & ND & ND & ND \\
\hline Copper, total, $\mathrm{mg} / \mathrm{L}$ & SW6010 & 0.030 & ND & ND & ND \\
\hline Copper, dissolved, mg/L & SW6010 & 0.030 & ND & ND & ND \\
\hline Iron, total, mg/L & SW6010 & 0.040 & $0.49 / \mathrm{D}$ & 0.50 & 1.1 \\
\hline Iron, dissolved, mg/L & SW6010 & 0.040 & ND & ND & ND \\
\hline Lead, total, mg/L & SW6010 & 0.20 & ND & ND & ND \\
\hline Lead, dissolved, $\mathrm{mg} / \mathrm{L}$ & SW6010 & 0.20 & ND & ND & ND \\
\hline Manganese, total, $\mathrm{mg} / \mathrm{L}$ & SW6010 & 0.010 & ND & 0.018 & 0.023 \\
\hline Manganese, dissolved, $\mathrm{mg} / \mathrm{L}$ & SW6010 & 0.010 & ND & ND & ND \\
\hline Molybdenum, total, $\mathrm{mg} / \mathrm{L}$ & SW6010 & 0.040 & ND & ND & ND \\
\hline Molybdenum, dissolved, $\mathrm{mg} / \mathrm{L}$ & SW6010 & 0.040 & ND & ND & ND \\
\hline Nickel, total, mg/L & SW6010 & 0.040 & ND & ND & ND \\
\hline Nickel, dissolved, mg/L & SW6010 & 0.040 & ND & ND & ND \\
\hline Selenium, total, $\mathrm{mg} / \mathrm{L}$ & SW6010 & 0.40 & ND & ND & ND \\
\hline Selenium, dissolved, $\mathrm{mg} / \mathrm{L}$ & SW6010 & 0.40 & ND & ND & ND \\
\hline Silver, total, mg/L & SW6010 & 0.030 & ND & ND & ND \\
\hline Silver, dissolved, $\mathrm{mg} / \mathrm{L}$ & SW6010 & 0.030 & ND & ND & ND \\
\hline Thallium, total, $\mathrm{mg} / \mathrm{L}$ & SW6010 & 5.0 & $\mathrm{ND} / \mathrm{C}$ & ND/C & $\mathrm{ND} / \mathrm{C}$ \\
\hline Thallium, dissolved, $\mathrm{mg} / \mathrm{L}$ & SW6010 & 5.0 & $\mathrm{ND} / \mathrm{C}$ & $\mathrm{ND} / \mathrm{C}$ & $\mathrm{ND} / \mathrm{C}$ \\
\hline Vanadium, total, $\mathrm{mg} / \mathrm{L}$ & SW6010 & 0.040 & ND & ND & ND \\
\hline Vanadium, dissolved, $\mathrm{mg} / \mathrm{L}$ & SW6010 & 0.040 & ND & ND & ND \\
\hline Zinc, total, mg/L & SW6010 & 0.010 & $0.036 / \mathrm{L}$ & $0.058 / \mathrm{D}, \mathrm{L}$ & 0.030 \\
\hline Zinc, dissolved, $\mathrm{mg} / \mathrm{L}$ & SW6010 & 0.010 & ND & ND & ND \\
\hline Total petroleum hydrocarbons, $\mathrm{mg} / \mathrm{L}$ & E418.1 & 1.0 & ND & ND & ND \\
\hline Total organic carbon, $\mathrm{mg} / \mathrm{L}$ & SW9060 & 1.0 & ND & ND & ND \\
\hline Total organic halogen as chloride, $\mu \mathrm{g} / \mathrm{L}$ & SW9020 & 30.0 & ND & ND & ND \\
\hline
\end{tabular}


Table 15.--Data-qualifier codes used to qualify water-quality data

\footnotetext{
Dataqualifier code Definition

A Reported results may be less than the actual value or possibility of a false non-detect exists because the sample was extracted or analyzed after the required analytical holding-time limits.

B Associated surrogate-recovery sample results did not meet the frequency or qualitycontrol acceptance criteria.

C Reported results did not meet the project reporting limits.

D Associated field-duplicate sample results did not meet the frequency or quality-control acceptance criteria.

E Associated equipment blank results did not meet the frequency or quality-control acceptance criteria.

F Associated ambient-conditions blank results did not meet the frequency or qualitycontrol criteria.

G Associated trip blank results did not meet the frequency or quality-control criteria.

$\mathrm{H} \quad$ Reported value may be biased high because the quality-control results are substantially greater than the quality-control limits.

I Reported value may be biased low because the quality-control results are substantially less than the quality-control limits.

J Associated laboratory duplicate-control sample results did not meet the frequency or quality-control acceptance criteria.

K Associated laboratory single-control sample results did not meet the frequency or quality-control acceptance criteria.

L Associated method blank results did not meet the frequency or quality-control acceptance criteria.

M Associated matrix spike or matrix-spike duplicate sample results did not meet the frequency or quality-control acceptance criteria.

$\mathrm{N}$ Instrument tuning, calibration, internal standards, or performance results did not meet the frequency or quality-control acceptance criteria.

O Problems with inductively coupled plasma analysis such as interelemental interferences or serial dilution. (This qualifier is to be used only with inorganic data.)

P Reported result was more than the highest calibration of method limits or exceeded the instrument's linear range.

Q Reported result was less than the lowest calibration, target-detection, reporting, or method limits or was below the instrument's linear range.

$\mathrm{R} \quad$ Problems in the sampling or analysis process such as field or laboratory contamination of a sample.
} 
Table 15.--Data-qualifier codes used to qualify water-quality data--Concluded

Data-

qualifier

code

Definition

$\mathrm{S}$

The sample result (positive or not detected) is considered conditionally rejected because of serious deficiencies in the ability to analyze the sample, or the qualitycontrol or confirmation acceptance criteria were substantially outside the required limits. Resampling or reanalysis may be necessary to verify the presence or absence of the constituent.

$\mathrm{T}$ The reported positive sample result is considered not reliable because of substantial contamination in the associated blanks on the basis of the following criteria:

(1) concentration of analyte that is a common laboratory organic contaminant has a concentration less than 10 times the concentration in the associated blank, or (2) other analytes have concentrations less than five times the concentration in the associated blank.

$\mathrm{U} \quad$ The reported positive sample result is considered an estimated quantity or questionable because: (1) there were analysis problems, (2) the quality-control or confirmation acceptance criteria were not met, (3) the amount reported is less than or more than the calibration or methods limits, or (4) the amount reported is less than the reporting or target-detection limits.

$\mathrm{V}$ The reported not-detected (ND) sample result is questionable because of analysis problems or quality-control acceptance criteria were not met.

W The identification of a tentatively identified compound (TIC) is questionable and the reported positive result for the TIC is strictly an estimated value because normal analysis and quality-control acceptance criteria do not apply directly to the reported TIC result. (This data-qualifier code is to be used only with TIC data.)

$X \quad$ The identification of a TIC is questionable and the reported positive result is considered not reliable because this TIC was also detected in an associated quality-control blank. (This data-qualifier code is to be used only with TIC data.)

$\mathrm{Y} \quad$ The identification of a TIC is questionable and the reported positive result is considered as conditionally rejected because this TIC is considered a common laboratory contaminant. (This data-qualifier code is to be used only with TIC data.)

$\mathrm{Z} \quad$ This data-qualifier code is used for specific analytical results that have data-quality problems not covered or represented in this list. If this code is used, some explanation is needed to describe the specific data-quality problem. 
No volatile or semivolatile organic compounds were detected above the laboratory reporting limits during the initial sampling round in December 1993 with the exception of the semivolatile compound cyclopentane, ethyl- (table 11). This compound was tentatively identified in water samples from wells MW1 and MW3 at concentrations of 4.3 and $4.2 \mu \mathrm{g} / \mathrm{L}$, respectively. Cyclopentane, ethyl- was also tentatively identified in the equipment blank for well MW3 at a concentration of $4.3 \mu \mathrm{g} / \mathrm{L}$. The tentative identification of this compound is strictly an estimate based on the laboratory detection of an unknown compound through gas chromatograph/mass spectrometer (GC/MS) analysis. The mass spectrum of chromatographic peaks generated by the GC/MS analysis was compared to a library of reference spectra, which was then reviewed by an analyst who tentatively identified the compound on the basis of available information. The tentatively identified compound (TIC) was quantified based on the total ionization peak area relative to an internal laboratory standard. There is no identified method for the accurate detection of cyclopentane, ethyl-; therefore, laboratory quality-control acceptance criteria do not apply directly to this TIC. Cyclopentane occurs in petroleum and is found in petroleum ether fractions (Budavari and others, 1989). Cyclopentane, ethyl- is an isomeric compound of hexane that is used to clean sampling equipment. Although hexane was not used to clean sampling equipment used at the Chromic Acid Pit site, it had previously been used to clean the stainless steel cable used during the bailing process. Because this TIC was also tentatively identified in an equipment blank at equal or higher concentrations as the two environmental samples (Rocky Mountain Analytical Laboratory, written commun., December 1993), the samples were assumed to have been contaminated during collection.

Metals identified in concentrations above the reporting limits in ground-water samples from the three chromic acid pit monitoring wells include aluminum (total), barium (total and dissolved), beryllium (total), chromium (total and dissolved), iron (total and dissolved), manganese (total and dissolved), nickel (total), vanadium (total and dissolved), and zinc (total and dissolved). Concentrations of each of these metals were detected in water from background well MW1 (with the exception of beryllium and nickel) as well as downgradient wells MW2 and MW3, signifying their presence in the Hueco Bolson deposits. Total beryllium was identified in water samples from wells MW2 and MW3 both at concentrations of $0.0023 \mathrm{mg} / \mathrm{L}$, just above the Appendix IX practical quantitation limit, or laboratory reporting limit, of $0.0020 \mathrm{mg} / \mathrm{L}$ (practical quantitation limit is the lowest concentration of an analyte in ground water that can be reliably determined within specified limits of precision and accuracy by the indicated methods under routine laboratory operating conditions; U.S. Environmental Protection Agency, 1993, Appendix IX); total nickel was identified in water from well MW3 during the March 1994 sampling event at a concentration of $0.063 \mathrm{mg} / \mathrm{L}$. Detected concentrations of total chromium ranged from 0.0099 to $0.092 \mathrm{mg} / \mathrm{L}$; detected concentrations of dissolved chromium ranged from 0.0068 to $0.0094 \mathrm{mg} / \mathrm{L}$. Results for some metals had associated qualifiers (tables 11-14).

Detected metal concentrations in water from the chromic acid pit monitoring wells during the four sampling periods were below EPA-identified maximum contaminant levels (table 16) for public drinking water supplies. Detected concentrations of total aluminum and total iron in water from wells MW1, MW2, and MW3, and dissolved iron and total manganese in water from well MW3 were above EPA advisable maximum levels (secondary maximum contaminant levels; table 16) for public drinking water supplies. Several reported values of aluminum and iron were qualified with associated matrix interferences that may result in values being biased high; some reported values did not meet field-duplicate $Q A / Q C$ requirements (tables 11-14). 
Table 16.--Summary of maximum contaminant levels for selected water-quality properties and constituents for public water-supply systems ${ }^{1}$

$$
\text { [--, no data; } \mathrm{mg} / \mathrm{L} \text {, milligrams per liter }]
$$

\begin{tabular}{lcc}
\hline \multicolumn{1}{c}{ Property or constituent } & Maximum contaminant level ${ }^{2}$ & $\begin{array}{c}\text { Secondary maximum } \\
\text { contaminant leve }{ }^{3}\end{array}$ \\
\hline $\mathrm{pH}$ (standard units) & - & Less than 6.5 and greater than 8.5 \\
Aluminum & - & $0.05-0.2 \mathrm{mg} / \mathrm{L}$ \\
Antimony & $0.006 \mathrm{mg} / \mathrm{L}$ & - \\
Arsenic & $0.05 \mathrm{mg} / \mathrm{L}$ & - \\
Barium & $2 \mathrm{mg} / \mathrm{L}$ & -- \\
Beryllium & $0.004 \mathrm{mg} / \mathrm{L}$ & - \\
Cadmium & $0.005 \mathrm{mg} / \mathrm{L}$ & - \\
Chloride & - & $250 \mathrm{mg} / \mathrm{L}$ \\
Chromium & $0.1 \mathrm{mg} / \mathrm{L}$ & - \\
Copper & - & $1.0 \mathrm{mg} / \mathrm{L}$ \\
Cyanide & $0.2 \mathrm{mg} / \mathrm{L}$ & - \\
Dissolved solids & - & $500 \mathrm{mg} / \mathrm{L}$ \\
Fluoride & $4.0 \mathrm{mg} / \mathrm{L}$ & $2.0 \mathrm{mg} / \mathrm{L}$ \\
Iron & - & $0.3 \mathrm{mg} / \mathrm{L}$ \\
Manganese & - & $0.05 \mathrm{mg} / \mathrm{L}$ \\
Mercury & $-.002 \mathrm{mg} / \mathrm{L}$ & - \\
Nickel & $0.1 \mathrm{mg} / \mathrm{L}$ & - \\
Nitrite plus nitrate & $10 \mathrm{mg} / \mathrm{L}$ & - \\
Nitrate as nitrogen & $10 \mathrm{mg} / \mathrm{L}$ & - \\
Nitrite as nitrogen & $1 \mathrm{mg} / \mathrm{L}$ & - \\
Selenium & $0.05 \mathrm{mg} / \mathrm{L}$ & - \\
Silver & - & $0.1 \mathrm{mg} / \mathrm{L}$ \\
Sulfate & - & $250 \mathrm{mg} / \mathrm{L}$ \\
Thallium & $0.002 \mathrm{mg} / \mathrm{L}$ & - \\
Zinc & - & $5.0 \mathrm{mg} / \mathrm{L}$ \\
\hline & & - \\
& & - \\
& &
\end{tabular}

${ }^{1}$ Public water-supply system-A system for the provision of piped water to the public for human consumption, if such system has at least 15 service connections or regularly serves at least 25 individuals daily at least 60 days of the year.

${ }^{2}$ Maximum contaminant level-Maximum permissible level of a contaminant in water that is delivered to the free-flowing outlet of the ultimate user of a public water system. Maximum contaminant levels are set by the U.S. Environmental Protection Agency (1994) in the National Primary Drinking Water Regulations. These regulations deal with contaminants that may have a substantial direct impact on the health of the consumer and are enforceable by Federal law.

${ }^{3}$ Secondary maximum contaminant level--Advisable maximum level of a contaminant in water that is delivered to a free-flowing outlet of the ultimate user of a public water system. Secondary maximum contaminant levels are proposed by the U.S. Environmental Protection Agency (1994) in the National Secondary Drinking Water Regulations. These regulations deal with contaminants that may not have a substantial direct impact on the health of the consumer, but whose presence in excessive quantities may affect the aesthetic qualities of the water and may discourage the use of a drinking water supply by the public. 
The chromic acid pit ground-water monitoring wells were completed with a 5-foot stainless steel sump and stainless steel wire-wrap screen (figs. 3-5). The composition for stainless steel water-well casing and sump, assuming type 304 stainless steel was used (not specified by contractor who completed wells), is as follows (Driscoll, 1986):
Chromium - 18 percent minimum;
Nickel - 8 percent minimum;
Manganese - 2 percent maximum;
Carbon - 0.08 percent maximum; and,
Iron - balance.

Driscoll (1986) described type 304 stainless steel as having excellent corrosion resistance and as being the most widely used stainless steel material for water-well screens. Monitoring well MW3 contains 80 feet of stainless steel screen and wells MW1 and MW2 contain 45 feet (figs. 3-5).

Although the type of stainless steel material assumed to have been used may be resistant to corrosion, high concentrations of iron, manganese, and, at times, chromium may be due to the chemical leaching of the screen and sump material, as well as the stainless steel cable used in purging the wells. In addition, PVC bailers used to purge the wells and Teflon bailers and bottom-emptying devices used to sample the wells were wrapped in aluminum foil for transport; these may have also contributed to the elevated concentrations of aluminum in ground-water samples. Total metal concentrations detected in equipment blanks (Rocky Mountain Analytical Laboratory, written commun., December 1993; March, July, September, and October 1994) collected during the first year of quarterly water sampling included: (1) chromium detected in 10 of 12 samples ranging from 0.0013 to $0.0033 \mathrm{mg} / \mathrm{L}$; (2) zinc detected in 4 of 12 samples ranging from 0.018 to $0.069 \mathrm{mg} / \mathrm{L}$; (3) iron detected in 2 of 9 samples at concentrations of 0.093 and $0.16 \mathrm{mg} / \mathrm{L}$; (4) aluminum detected in 1 of 9 samples at $0.24 \mathrm{mg} / \mathrm{L}$; and (5) manganese detected in 1 of 9 samples at $0.056 \mathrm{mg} / \mathrm{L}$. Unless qualified in tables 11-14, the detections of these metals in the equipment blanks were within acceptable QA/QC limits.

No petroleum hydrocarbons were detected at or above the reporting limit in any of the chromic acid pit monitoring wells (tables 11, 13-14) during the first year of quarterly monitoring. Concentrations of total organic carbon were detected once in each well (three of nine water samples total) and ranged from 1.3 to $1.7 \mathrm{mg} / \mathrm{L}$; each of these analyses had related matrix interferences or did not meet the QA/QC criteria for duplicate samples (tables 12-14). Concentrations of total organic halides were detected during the March sampling in wells MW1 and MW2 at concentrations of 104 and $59.4 \mu \mathrm{g} / \mathrm{L}$, respectively; these samples had related matrix interferences or did not meet QA/QC duplicate sample criteria (tables 12-14). Overall, chemical concentrations in water from the chromic acid pit monitoring wells were similar to those in water from other wells in the vicinity (tables 10-14).

\section{Statistical Analysis of Water-Quality Data}

Hypothesis tests were performed on water-quality data for chromic acid pit ground-water monitoring wells MW1, MW2, and MW3 to determine whether water quality at either downgradient, or compliance, well (MW2 and MW3) was significantly different than that at the background well (MW1). Water-quality data used in the hypothesis tests were from samples collected on a quarterly basis (four quarters total) between December 7, 1993, and September 15, 1994 (tables 11-14).

Sufficient background and compliance data were available for statistical analysis after a minimum of four water samples were collected from each well over the 12-month period ending December 1994. Samples were collected at four intervals (December 1993; March, June, and September 1994) during the year to assure that independent samples were obtained (most intiatical procedures are based on the assumption of independence). 
Because the constituents for analysis were modified after the first quarterly sampling event, some constituents did not meet the minimum requirement of four sample points. The sample size at each well varied from three to four observations (tables 11-14). Only environmental samples with the minimum requirement of four observations per well were tested. Duplicate and other QC samples are not included in the sample set because they are not considered to be independent measurements.

\section{Procedure}

The procedure for the hypothesis tests followed the flowchart shown in figure 18. Waterquality data for MW1, MW2, and MW3 were examined to determine if the proportion of nondetect values for each water-quality constituent was greater than or equal to 15 percent. If the proportion of nondetect values was greater than or equal to 15 percent then a nonparametric hypothesis test was performed. If the proportion of nondetect values was less than 15 percent then a parametric hypothesis test was performed, if it met the criteria described below. For both nonparametric and parametric hypothesis tests all nondetect values in the data were replaced with a value equal to the laboratory reporting limit divided by two.

The nonparametric hypothesis-test procedure is based on taking the ranks of a variable and analyzing these ranks instead of the original values. The Statistical Analysis System (SAS) Institute NPAR1WAY procedure (SAS Institute, Inc., 1990b, p. 1195-1210) was used to perform the hypothesis test. This procedure determines whether the distribution of a variable has the same location parameter across different groups using a one-way analysis of variance on the ranked data, and computes the Kruskal-Wallis test statistic, which was used to judge the outcome of the hypothesis test. If the Kruskal-Wallis test statistic indicated a significant difference among MW1, MW2, and MW3 then pairwise hypothesis tests were performed between MW1, MW2, and MW3. The SAS Institute NPAR1WAY procedure (SAS Institute, Inc., 1990 b, p. 1195-1210) was used to compute the Wilcoxon-Rank-Sum test statistic. This test statistic was used to judge whether water quality at either downgradient well was significantly different than that at the background well.

The parametric hypothesis-test procedure requires that two assumptions about the data be satisfied: (1) the data or the log-transformed data for MW1, MW2, and MW3 must fit a normal distribution; and (2) the variances for the data or the log-transformed data at MW1, MW2, and MW3 must be approximately equal. The SAS Institute UNIVARIATE procedure (SAS Institute, Inc., 1990b, p. 617-634) calculates the Shapiro-Wilk statistic, which was used to test the MW1, MW2, and MW3 data and the log-transformed MW1, MW2, and MW3 data for normality. The SAS Institute Levene's Test (SAS Institute, written commun., 1995) was used to test the MW1, MW2, and MW3 data for homogeneous variances. The SAS Institute ANOVA procedure (SAS Institute, Inc., 1990b, p. 209-244) was used to perform the hypothesis test; an F statistic was computed and used to judge the outcome of the hypothesis test. If the F statistic indicated a significant difference among MW1, MW2, and MW3 then pairwise hypothesis tests were performed between MW1, MW2, and MW3. The SAS Institute TTEST procedure (SAS Institute, Inc., 1990b, p. 1633-1640) was used to compute the $t$ statistic, which was used to judge whether water quality at any downgradient well was significantly different from water quality at the background well. If either of the two assumptions about the data was not satisfied, the nonparametric test was performed.

\section{Results}

Results of hypothesis tests on water-quality data for 39 chemical constituents at wells MW1, MW2, and MW3 are summarized in table 17. Significant differences were determined at the 95-percent confidence level. This means that, on average, 1 time in 20 a significant difference will be determined when there is no significant difference. No calculation has been made of the number of times a real significant difference will be undetected. 


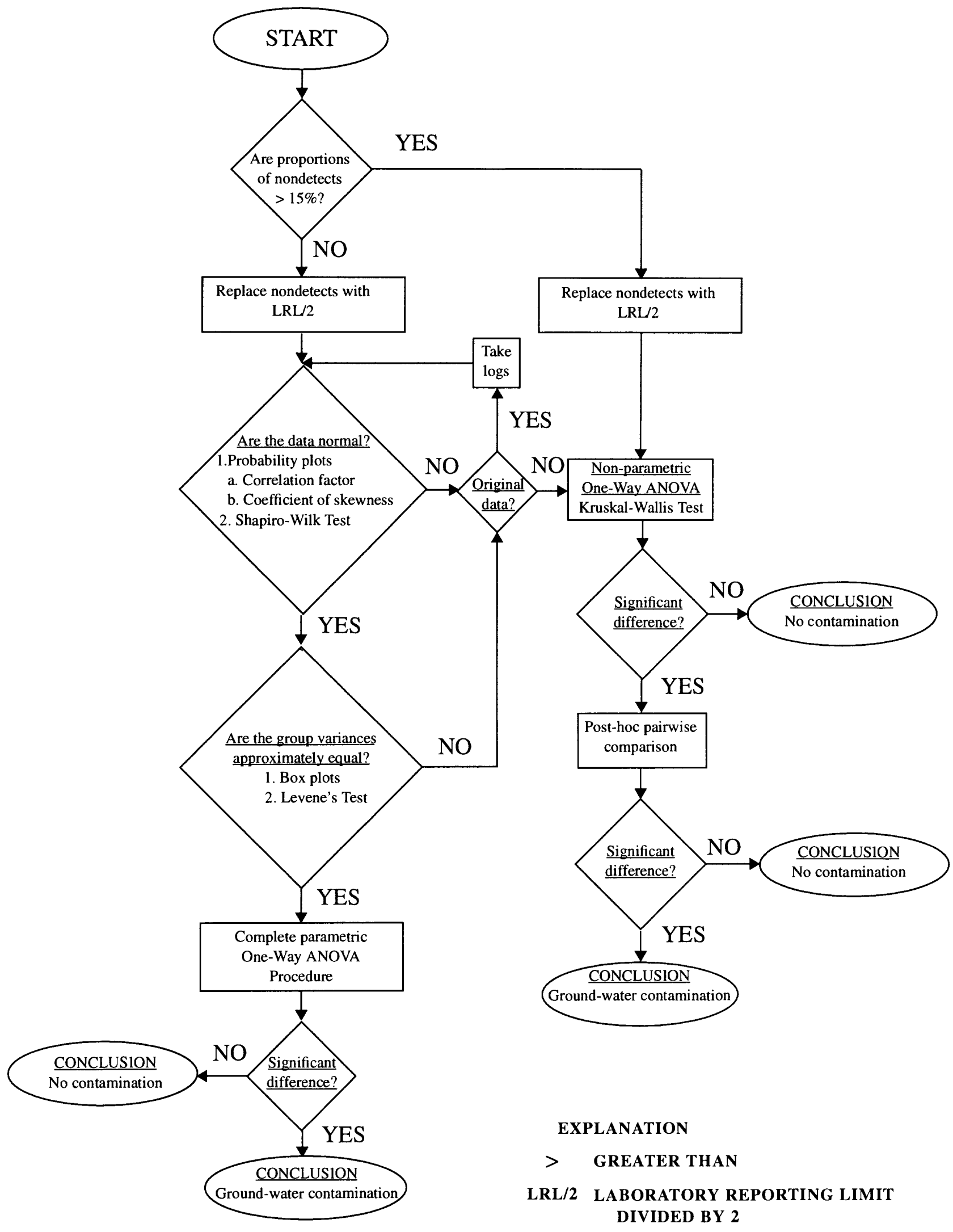

Figure 18.--Methods used for statistical analysis of water-quality data. 

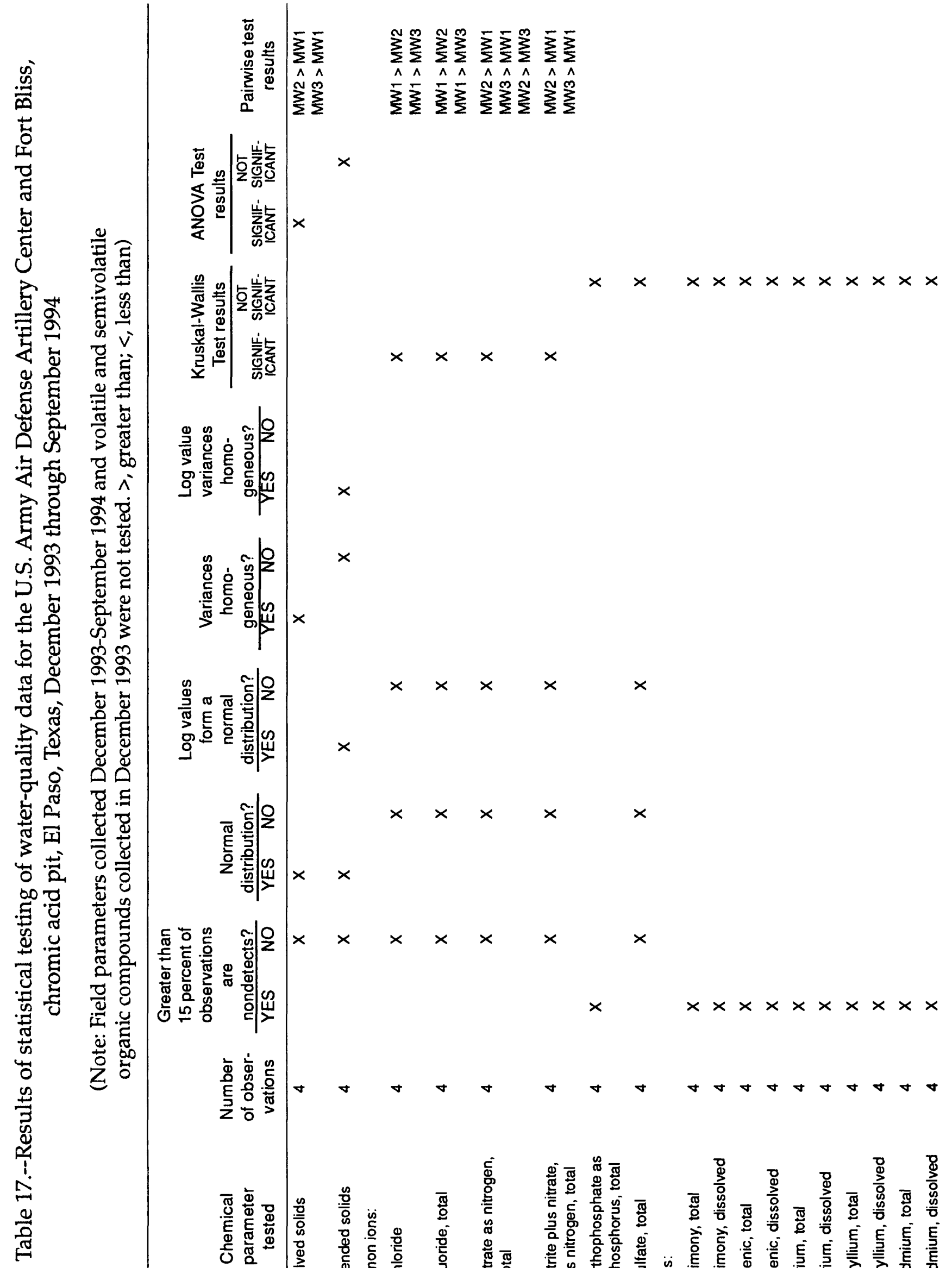

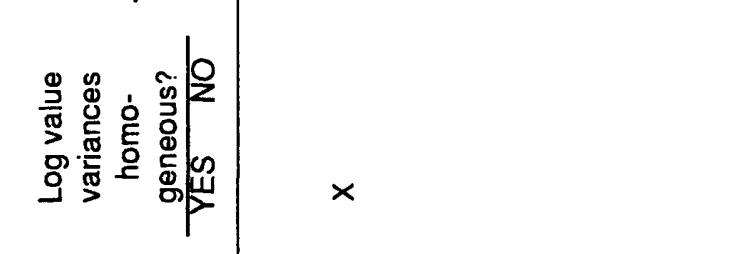

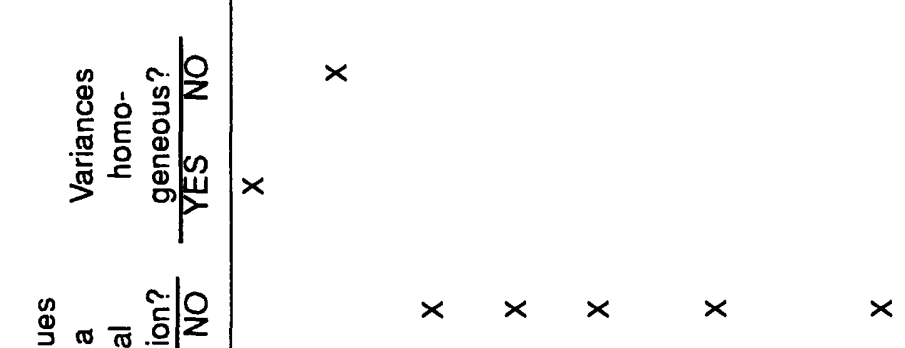

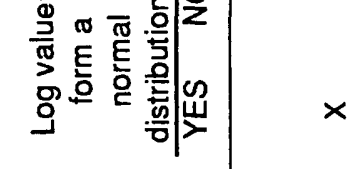
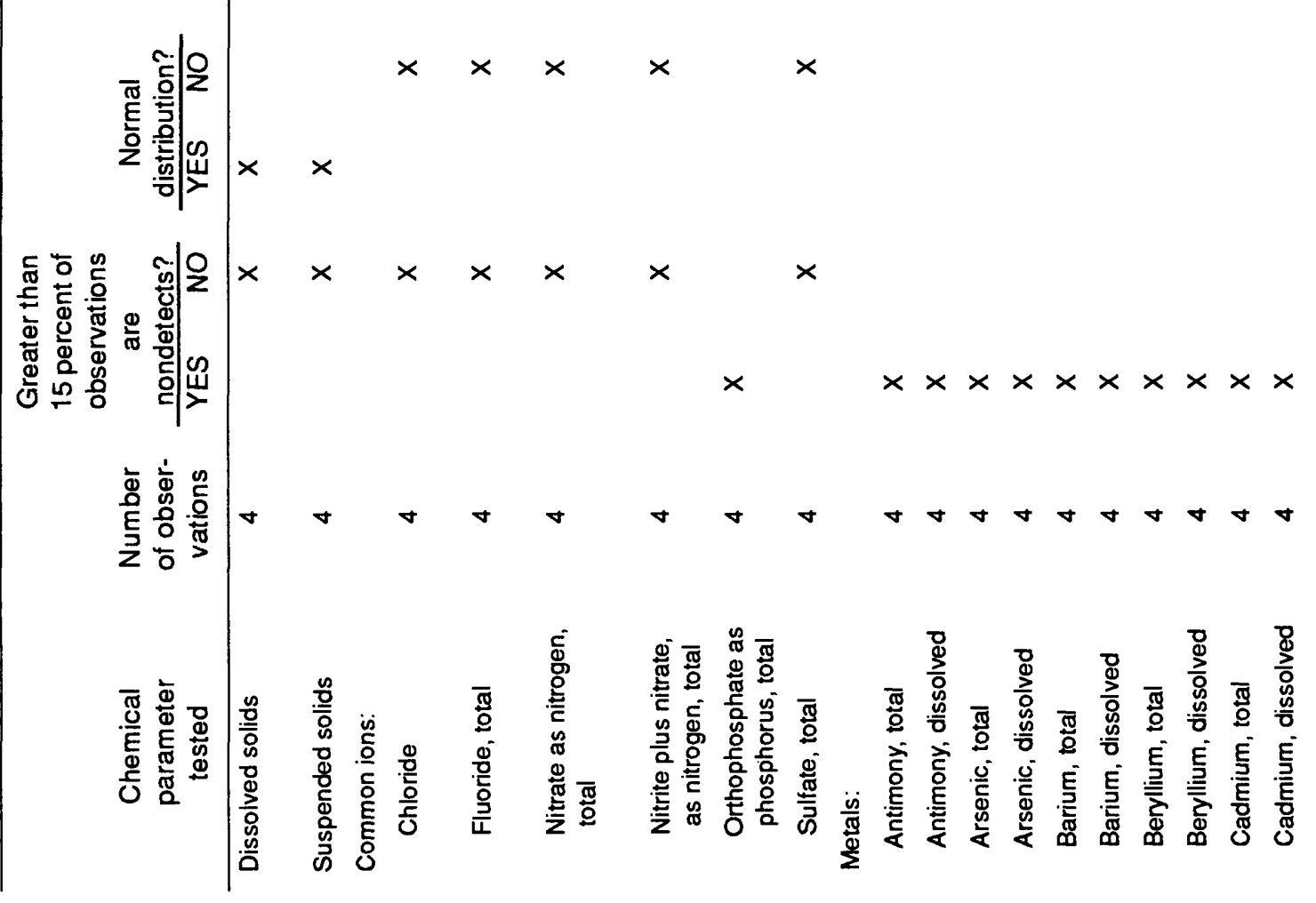
क्ष

它

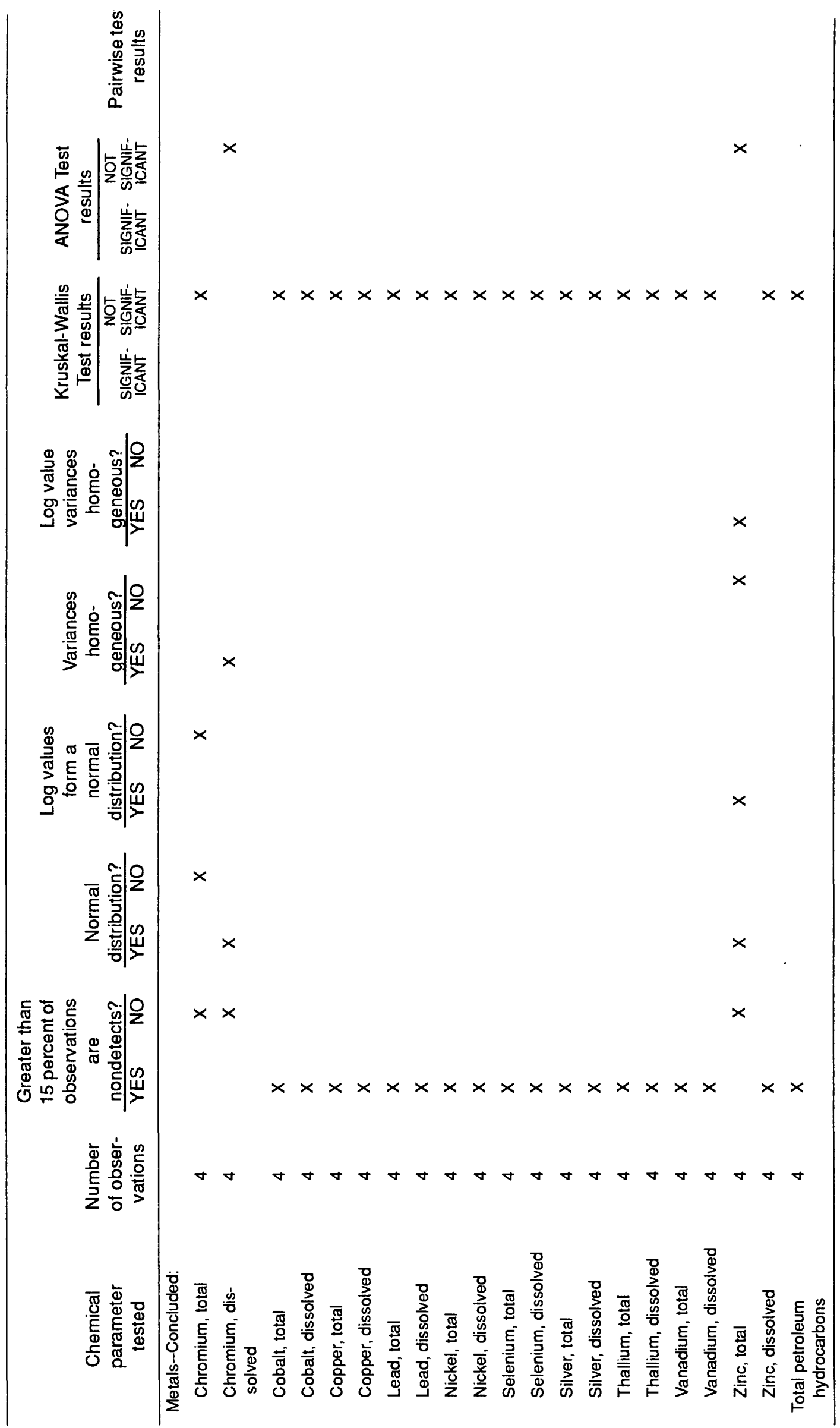


Significant differences were detected between ground water in the downgradient wells and ground water in the background well for the following chemical constituents: chloride, fluoride, nitrate as nitrogen, nitrite plus nitrate as nitrogen, and dissolved solids. Concentrations of chloride and fluoride were significantly less in water from downgradient wells MW2 and MW3 than in water from background well MW1. Concentrations of nitrate as nitrogen, nitrite plus nitrate as nitrogen, and dissolved solids were significantly greater in water from downgradient wells MW2 and MW3 than in water from background well MW1. The concentration of nitrate as nitrogen in water from downgradient well MW2 was significantly greater than water from downgradient well MW3. For all other laboratory-analyzed chemical constituents, no significant differences were detected at the 95-percent confidence level between water in the downgradient wells and water in the background well or between water in the two downgradient wells.

The significant differences between concentrations of chloride, fluoride, and dissolved solids in water from the background well and from the downgradient wells are assumed to be due in part to incomplete well development. Monitoring wells MW2 and MW3 contained significant amounts of drill mud and sediment prior to the initial sampling event. These wells cleared up significantly after purging the required volume. The significant difference of dissolved-solids concentrations may also be due in part to chemical reactions that could occur as a result of any leakage of cement grout into the screened interval in MW1 as discussed in the Ground-Water Quality section of this report. Significant differences in concentrations of nitrate as nitrogen and nitrite plus nitrate as nitrogen are attributed to the variable and abnormally high nitrate concentrations associated with the Old Mesa well field discussed previously.

Although significant differences were identified in concentrations of chloride, fluoride, nitrate as nitrogen, nitrite plus nitrate as nitrogen, and dissolved solids between water samples from background well MW1 and downgradient wells MW2 and MW3, these differences do not appear to be associated with release of contaminants from the chromic acid pit. Therefore, data collected and analyzed during the first year of quarterly ground-water monitoring at the Chromic Acid Pit site indicate no contamination due to potential leakage from the chromic acid pit.

\section{SUMMARY}

Hydrogeologic and water-quality conditions of the Chromic Acid Pit site on the USAADACENFB military reservation were evaluated. The chromic acid pit, located in El Paso, Texas, is a 2.2-cubic-yard concrete pit used from 1980 to 1983 for disposal of chromic acid waste generated from chrome plating operations. The RCRA-regulated chromic acid pit was certified closed in 1989 and is currently under post-closure care in accordance with TNRCC Permit No. HW-50296 (EPA Permit No. TX4213720101). Post-closure care requirements include routine maintenance of the site, conducted by USAADACENFB staff, and quarterly ground-water monitoring activities. Ground-water monitoring activities were initiated by construction of three monitoring wells by a private contractor. Ground-water monitoring well MW1 was installed hydraulically upgradient from the chromic acid pit; monitoring wells MW2 and MW3 were installed hydraulically downgradient from the chromic acid pit. The U.S. Geological Survey began quarterly ground-water monitoring at the site in December 1993 in accordance with a detailed, site-specific Sampling and Analysis Plan.

The chromic acid pit is underlain by Hueco Bolson deposits (reported maximum thickness 9,000 feet) of Tertiary age composed of alternating sand and gravel and clay and silt lenses with gradational zones of clayey sand, sandy clay, and sandy silty clay zones. No perennial or ephemeral streams are on or in the vicinity of the Chromic Acid Pit site. Moderately defined arroyos that flow only in response to intense rainstorms extend from the Franklin Mountains and drain into the Hueco Bolson 2 or more miles west of the Chromic Acid Pit site. Surface outflow at 
the Chromic Acid Pit site is negligible due to the absence of surface-water flow in the vicinity of the facility.

The primary source of ground water in the area of the Chromic Acid Pit site is the unconsolidated and semiconsolidated sedimentary deposits of the Hueco Bolson. An unsaturated zone of approximately 280 feet overlies the saturated Hueco Bolson deposits in the vicinity of the Chromic Acid Pit site. Recharge to the Hueco Bolson aquifer is primarily by inflow from the mountainous areas to the north, west, and east. Recharge resulting from direct infiltration of precipitation at the Chromic Acid Pit site is negligible due to high evaporation and low precipitation rates.

Extensive ground-water development by the City of El Paso and the U.S. Army encompasses the Chromic Acid Pit site; production wells are completed 600 to more than 1,200 feet below land surface. Transmissivities of the Hueco Bolson deposits under water-table conditions in the El Paso area have been estimated to be 1,340 to 37,520 feet squared per day $(10,000$ to 280,000 gallons per day per foot). The ground-water level in the vicinity of the Chromic Acid Pit site has declined 24.36 feet from 1982 to 1993. Direction of ground-water flow at the Chromic Acid Pit site is to the southeast; depth to water in September 1994 was 283 to 285 feet below land surface.

Ground water in the vicinity of the Chromic Acid Pit site typically contains concentrations of dissolved solids ranging from 320 to $522 \mathrm{mg} / \mathrm{L}$. When reported above the reporting limits, concentrations of dissolved chromium ranged from 5.9 to $10 \mu \mathrm{g} / \mathrm{L}$. Nitrate concentrates ranged from 1.2 to $12 \mathrm{mg} / \mathrm{L}$ and are reported to be above background levels. The source of the high nitrate concentrations was reported to be seepage from a drainage sump that collects impounded urban runoff from northeast El Paso and Fort Bliss located on the Old Mesa well field 4,000-5,500 feet southwest of the Chromic Acid Pit site.

Water samples from the chromic acid pit ground-water monitoring wells were collected and analyzed quarterly for physical properties, common ions, volatile and semivolatile organic compounds (first quarter only), metals, total organic carbons, and total organic halides (second, third, and fourth quarters), and total petroleum hydrocarbons. Water temperature ranged from 23.0 to $25.0^{\circ} \mathrm{C}$. Turbidity ranged from 5.73 to $122 \mathrm{NTU}$ 's; the higher turbidity values were measured in water from well MW3 during the first two quarters; higher values resulted from the presence of drilling mud, possibly still in the formation, from installation of the well. The $\mathrm{pH}$ of water samples from background well MW1 ranged from 8.22 to 9.09; $\mathrm{pH}$ in water samples from downgradient wells MW2 and MW3 ranged from 7.47 to 8.13. Water in well MW1 was more basic than water from wells MW1 and MW2 possibly due to cement grout getting into the screened interval. Over time, the $\mathrm{pH}$ in water from well $\mathrm{MW} 1$ is approaching $\mathrm{pH}$ values in water from wells MW2 and MW3; the pH of water samples from wells MW2 and MW3 are similar to $\mathrm{pH}$ in ground water in the vicinity of the Chromic Acid Pit site. Specific conductance of water from the chromic acid pit wells ranged from 698 to 834 microsiemens per centimeter at $25^{\circ} \mathrm{C}$.

Dissolved carbonate concentration in water samples, calculated from field alkalinity and $\mathrm{pH}$, ranged from zero to $41 \mathrm{mg} / \mathrm{L}$ in well $\mathrm{MW1}$; calculated carbonate concentration was zero in water from wells MW2 and MW3. Calculated bicarbonate concentration in water samples ranged from 50 to $193 \mathrm{mg} / \mathrm{L}$ in well MW1, from 227 to $233 \mathrm{mg} / \mathrm{L}$ in well MW2, and from 234 to $244 \mathrm{mg} / \mathrm{L}$ in well MW3. Alkalinity as calcium carbonate in water samples ranged from 109 to 162 $\mathrm{mg} / \mathrm{L}$ in well MW1, from 186 to $191 \mathrm{mg} / \mathrm{L}$ in well MW2, and from 192 to $200 \mathrm{mg} / \mathrm{L}$ in well MW3. Analyses for common ions included total chloride, fluoride, nitrate, orthophosphate, sulfate, and total and dissolved calcium, magnesium, potassium, and sodium. Ground water at the Chromic Acid Pit site generally contains relatively large amounts of sodium and bicarbonate. Nitrate as nitrogen concentrations in water samples ranged from 2.1 to $2.7 \mathrm{mg} / \mathrm{L}$; concentrations of nitrite plus nitrate as nitrogen ranged from 2.3 to $3.0 \mathrm{mg} / \mathrm{L}$. Dissolved-solids concentrations 
ranged from 442 to $564 \mathrm{mg} / \mathrm{L}$. Suspended-solids concentrations ranged from 5.2 to $47.2 \mathrm{mg} / \mathrm{L}$ in water samples from wells MW1 and MW2, and from 24 to $219 \mathrm{mg} / \mathrm{L}$ in water samples from well MW3; higher concentrations in MW3 were due to the presence of suspended sediment and drilling mud in the sample water from incomplete well development.

No volatile organic compounds were detected above laboratory reporting limits. The semivolatile compound cyclopentane, ethyl- was tentatively identified in water samples from background well MW1 and downgradient well MW3 at concentrations of 4.3 and $4.2 \mu \mathrm{g} / \mathrm{L}$, respectively. Cyclopentane, ethyl- was also tentatively identified in the equipment blank for well MW3 at a concentration of $4.3 \mu \mathrm{g} / \mathrm{L}$, indicating possible contamination of environmental samples with this compound during field collection.

Concentrations of metals that were identified above the reporting limits in ground-water samples from the chromic acid pit monitoring wells included aluminum, barium, beryllium, chromium, iron, manganese, nickel, vanadium, and zinc. These metals, with the exception of beryllium and nickel, were identified in water from background well MW1 as well as downgradient wells MW2 and MW3, signifying their presence in Hueco Bolson deposits. Detected concentrations of total chromium ranged from 0.0099 to $0.092 \mathrm{mg} / \mathrm{L}$; detected concentrations of dissolved chromium ranged from 0.0068 to $0.0094 \mathrm{mg} / \mathrm{L}$. The wells were completed with stainless steel screens and sumps that are alloys of iron, chromium, nickel, manganese, and carbon, possibly contributing to concentrations of these metals in the water samples. Detected chemical concentrations in water from the chromic acid pit monitoring wells during the four sampling periods were below EPA-identified maximum contaminant levels for public drinking water supplies.

No petroleum hydrocarbons were detected at or above the reporting limit. Total organic carbon was detected, once in each well, at concentrations ranging from 1.3 to $1.7 \mathrm{mg} / \mathrm{L}$; each sample had associated $\mathrm{QA} / \mathrm{QC}$ interferences. Total organic halides were detected during the March sampling event in wells MW1 and MW2 at concentrations of 104 and $59.4 \mu \mathrm{g} / \mathrm{L}$, respectively; each sample had associated QA/QC interferences. Overall, chemical concentrations in water from the chromic acid pit monitoring wells were similar to those in water from other wells in the vicinity.

Statistical analysis of water-quality data for 39 chemical constituents at wells MW1, MW2 and MW3 indicated significant differences between ground water in downgradient wells MW2 and MW3 and ground water in background well MW1 for chloride, fluoride, nitrate as nitrogen, nitrite plus nitrate as nitrogen, and dissolved solids. Chloride and fluoride were significantly less in water from downgradient wells MW2 and MW3 than in water from background well MW1 possibly due in part to well development differences. Nitrate as nitrogen, nitrite plus nitrate as nitrogen, and dissolved-solids concentrations were significantly greater in water from downgradient wells MW2 and MW3 than in water from background well MW1. Nitrate as nitrogen concentrations in water from downgradient well MW2 were significantly greater than in water from downgradient well MW3. Differences in dissolved-solids concentrations may be due in part to possible leakage of cement grout into the screened interval in MW1. Differences in concentrations of nitrate as nitrogen and nitrite plus nitrate as nitrogen are attributed to the variable nitrate concentrations in the aquifer as determined by data from the Old Mesa well field. Statistical analysis indicated no significant differences for all other laboratory-analyzed chemical constituents, at the 95-percent confidence level, between water from the downgradient wells and water from the background well or between water from the two downgradient wells. Differences detected through statistical analysis of chemical constituents of water in Chromic Acid Pit monitoring wells MW1, MW2, and MW3 do not appear to indicate a release of hazardous chemicals from the chromic acid pit. There is no indication of ground-water contamination in either of the downgradient wells. 


\section{REFERENCES}

Alvarez, H.J., and Buckner, A.W., 1980, Ground-water development in the El Paso region, Texas, with emphasis on the resources of the lower El Paso Valley: Texas Department of Water Resources Report 246, 346 p.

American Public Health Association and others, 1985, Standard methods for the examination of water and wastewater (16th ed.): American Public Health Association, Washington, D.C., $1268 \mathrm{p}$.

A.T. Kearney, Inc., 1989, RCRA Facility assessment, preliminary report/visual site inspection report, March 1989, Fort Bliss, Texas: A.T. Kearney, Inc., Chicago.

Budavari, Susan, O'Neil, J.J., Smith, Ann, and Hecklelman, P.E., eds., 1989, The Merck index: Merck and Co., Inc., Rahway, N.J., 11th ed., 10100 p. and appendices.

Cliett, Tom, 1969, Groundwater occurrence of the El Paso area and its related geology, in Guidebook of the Border Region: New Mexico Geological Society, 20th Field Conference, October 23, 24, and 25, 1969: New Mexico Geological Society, p. 209-213.

Driscoll, F.G., 1986, Groundwater and wells: Johnson Filtration Systems, Inc., St. Paul, Minn., 2d ed., $1,089 \mathrm{p}$.

Environmental Science and Engineering, Inc., 1983, Installation assessment of the Headquarters, October 1983, U.S. Army Air Defense Center and Fort Bliss, Texas: Environmental Science and Engineering, Inc. Report No. 335, Gainesville, Fla.

1991, Volume I, RCRA facility investigation report, Texas solid waste management units, December 1991, Fort Bliss, El Paso, Texas: Environmental Science and Engineering, Inc., Plymouth Meeting, Penn.

International Boundary and Water Commission, 1988, Flow of the Rio Grande and related data, 1988: U.S. of America, Department of State, International Boundary and Water Commission, United States and Mexico, Water Bulletin Number 58, 144 p.

Jaco, H.B., 1971, Soil survey of El Paso County, Texas: U.S. Department of Agriculture, Soil Conservation Service, November 1971, 59 p., 62 sheets, and explanation p.

Mattick, R.E., 1967, A seismic and gravity profile across the Hueco Bolson, Texas: U.S. Geological Survey Professional Paper 575-D.

SAS Institute, Inc., 1990a, SAS Procedures Guide, Version 6, 3d ed.: SAS Institute, Inc., Cary, N.C., $705 \mathrm{p}$.

1990b, SAS/STAT\# User's Guide, Version 6, 4th ed.: SAS Institute, Inc., Cary, N.C., 1686 p.

Sayre, A.N., and Livingston, Penn, 1945, Ground-water resources of the El Paso area, Texas: U.S. Geological Survey Water-Supply paper 919, $190 \mathrm{p}$.

Texas Natural Resources Conservation Commission, 1993, 30 TAC 330, Municipal solid waste: Texas Register, Austin, Tex., 194 p. plus updates through December 1993.

U.S. Army Environmental Hygiene Agency, 1987, Interim final report, evaluation of solid waste management units, August 1987, Fort Bliss, Texas: U.S. Army Environmental Hygiene Agency, Aberdeen Proving Ground, Md. 


\section{REFERENCES--Concluded}

U.S. Army Environmental Hygiene Agency, 1989, Final report, evaluation of solid waste management units, 3-7AUG1987 and 26-29SEP1989, Fort Bliss, Texas: U.S. Army Environmental Hygiene Agency, Aberdeen Proving Ground, Md.

U.S. Department of Commerce, National Oceanic and Atmospheric Administration, Environmental Data Service, 1992, Annual summary, Texas: National Oceanic and Atmospheric Administration, v. 97, no. 13, 80 p.

U.S. Environmental Protection Agency, 1983, Methods for chemical analysis of water and wastes: U.S. Environmental Protection Agency Manual 600/4-79-020.

1986a, Inductively coupled plasma-atomic emission spectrometer method for trace element analysis of water and wastes: Federal Register, 40CFR 261, App. C, July 1, 1986.

1986b, Methods for organic chemical analysis of municipal and industrial wastewater: Federal Register, 40CFR 136, App. A, July 1, 1986.

1986c, Test methods for evaluating solid waste, physical/chemical methods, SW-846 (3d ed.): U.S. Environmental Protection Agency.

1989, Statistical analysis of ground-water monitoring data at RCRA facilities (interim final guidance): U.S. Environmental Protection Agency, Office of Solid Waste, February 1989.

1992, Statistical analysis of ground-water monitoring data at RCRA facilities (Draft addendum to interim final guidance): U.S. Environmental Protection Agency, Office of Solid Waste, July 1992, 84 p. and appendices.

1993, Code of Federal regulations, Title 40, Environment, Part 264, Appendix IX, Groundwater monitoring list: Federal Register, July 1, 1993.

1994, Summary of EPA finalized national primary drinking water regulations: U.S. Environmental Protection Agency, July 1994, 7 p.

White, D.E., 1987, Summary of hydrologic information in the El Paso, Texas, area with emphasis on ground-water studies, 1903-80: Texas Water Development Board Report 300, 75 p. 